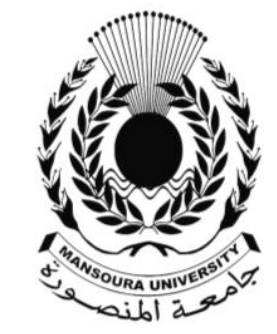

جامعة المنصـورة المانئ

$$
\text { كليـة الآداب }
$$

\title{
الأبعاد الاجتماعية والاقتصادية لظاهرة التنـمر دراسة هيدانية على طلاب المرحلة الثانوية بمدينة المنصورة
}

\author{
|c|
}

نيفين ابراهيم محمد فتحي ابراهيم ابو على

دكتوراه في علم الاجتماع

كلية الآداب - جامعة المنصورة

مجـلة كلــية الآداب - جـامعـة المنصــورة

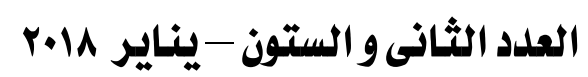




\section{الأبعاد الإتتما عية والاقتصادية لظاهرة التنـمر \\ دراسة ميدانية على طلاب المرهلة الثانوية بمدينة المنصورة}

\section{نيفين ابراهيم محمد فتحي ابراهيم ابو على}

\section{الملخص:}

هدف البحث الراهن إلى التعرف على الأبعاد الاجتماعية والثقافية لظاهرة التندر في الددارس الثانوية ولتحقيق أهداف البحث

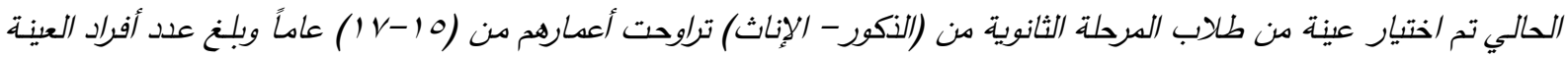
(ro.) مفردة تم اختيارهم بالطريقة العشوائية البسيطة. ثم استخدت الباحثة أداة الاستبيان لإجراء البحث الديداني وجدع البيانات

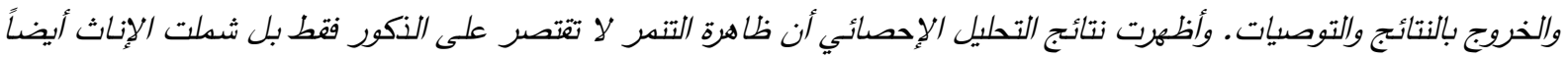

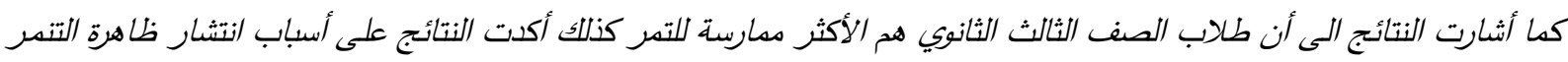

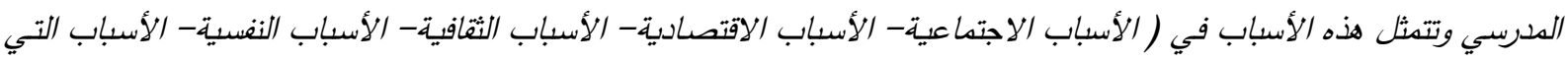
تتعلق بالطالب نفسه وغيرها).

\section{Abstract}

The aim of the current research is to identify the social and cultural dimensions of the bullying phenomenon in secondary schools. To achieve the current research objectives, a sample of (male and female) secondary students aged( 15-17 )years were selected. The sample consisted of (250) In a simple random way.

The researcher then used the questionnaire tool to conduct field research, collect data and come up with conclusions and recommendations.

The results of the statistical analysis showed that the phenomenon of bullying is not limited to males only, but also to females. The results also indicate that the third year secondary students are the most practicing dates. The results also confirm the causes of the spread of bullying school. These reasons are (social reasons -economic reasons - cultural causes - psychological reasons - reasons related to the student himself and others).

مقدمة: مقد

والمناسـبة لإعـداد اجيـال تتحلى بالعقـل والابـداع

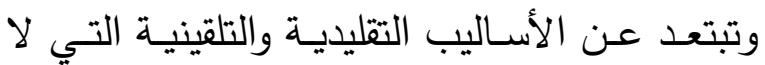

تفرزاجيالا قادة على التصدي لمشكلاتها المتوقعة

، كمـا تعمل المؤسسـات التربويـة على الحــ مـن

المشـكلات والاضـطرابات السـلوكية التي تواجـهـ

التلاميذـ والتـي مـن بينهـا التتمـر المدرسـي الـذي

اصبح مشكلة تعانى منها كل مدرسة وأسرة تقريبا

يعتبـر التتمـر المدرسـي شـكلا مـن اشـكال

السلوك العدواني غير المتوازن وهو يحدث بصورة

متكرر في علاقـات الاقران في البيئة المدرسـية
ان المؤسسات التعليمية تقوم بتعليم الطلبة

المهـارات وتوسـيع قاعدة معلومـاتهم ومعـارفهم،

وتجعلهم اكثر قدرة على مواجهة حل المشكلات

التعليمية في الجانب الدراسي وحياتهم المستقبلية

، فهي تسـي الـى التنمرالمتكامسل في النـواحي

العقليـة والنفسية والاجتماعيـة، الـى اقصسي حد

وتمكـنهم الافــادة مـن قـدراتهم واسـتعداداتهم

وتعمل التربية الى تزويد الطلبة بأفكار واسـاليب

عقلية جديده تمكنهم من زيادة رغبتهم ودافعيتهح

للــتعلم ، وتــوفير الطــرق والاســاليب المبتكــرة 
معدودات، وأصبح مـا يعانيـه الغرب بالذات من

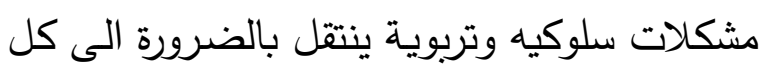

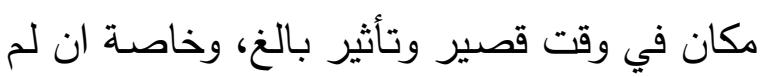
ينتبه المربون في الاسر والمدارس على ما تحمله تللك الظواهز السلبية مـن تداعيات. ومـع انتثـار وسائل الاتصـال الحديثة اعتاد كثير مـن الابنـاء

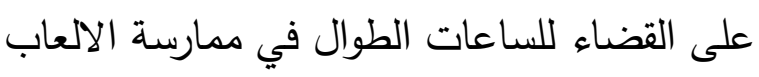

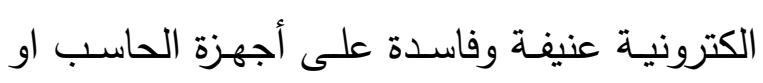

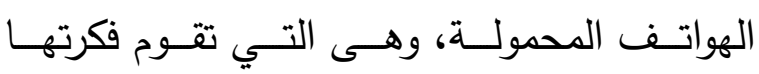
الاساسية والوحيدة على مفاهيم مثل القوة الخارقة

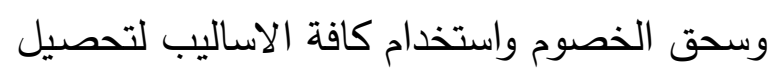

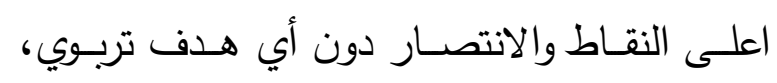

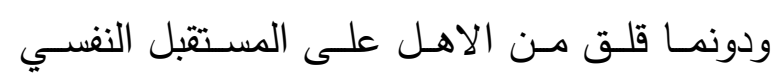
لهؤلاء الابناء اللذين يعتبرون الحياه استكمال لهذه الهـ الهي المباريـات، وتقوي عندهم النزعـة العدائية لغيرهم

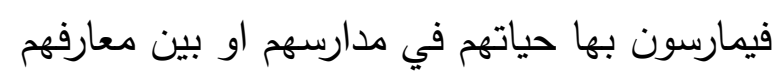

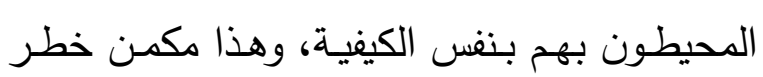

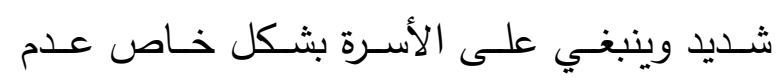

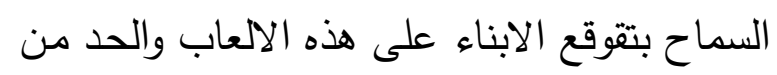

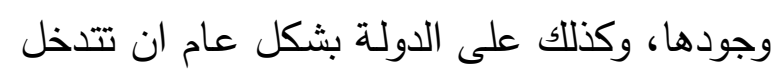

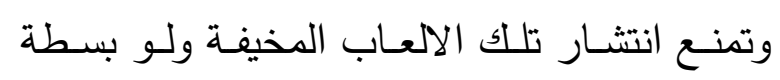

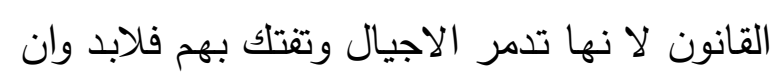

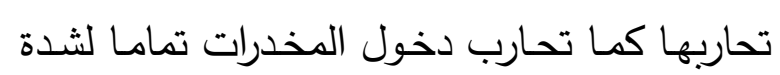

خطورتها.

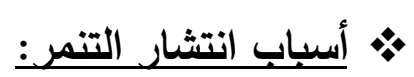

لـم يكن استخدام القوة بـين الاقران سـلوكا

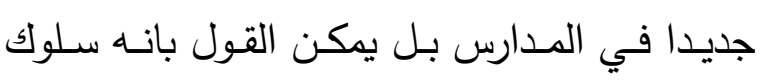

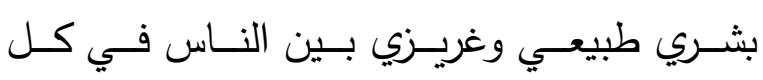

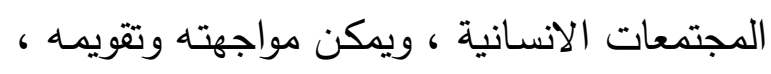

ويعتمـد على السـيطرة والـتحكم والادعـاء بـين طرفين أحدهما متتمر وهو الذي يقوم بالاعتداء

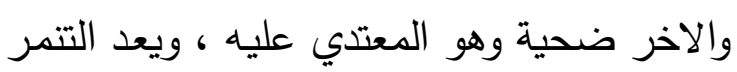
بما يحمله من عدوان تجاه الاخرين سواء كان

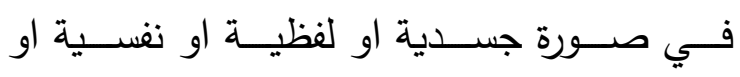

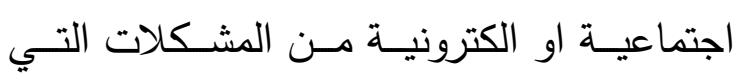

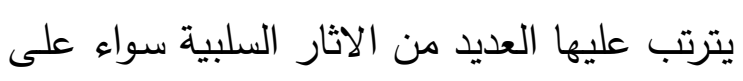

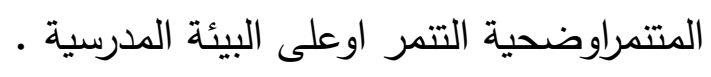
وبدأت ظاهرة التتمر يشتكي منها العالم كله

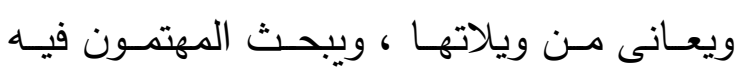

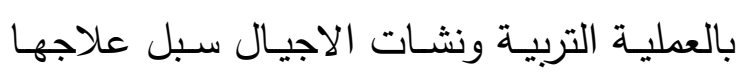
لخطورتها ، وذلك منذ وقت طويل ، وتلقى تلك

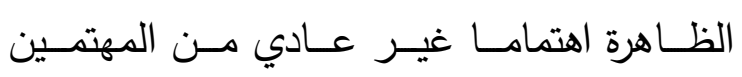

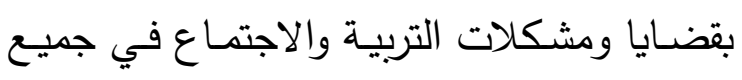

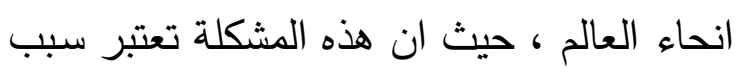

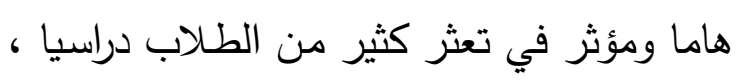
وقد تدفع بالبعض الى كره الدراسة وتركها بالكلية

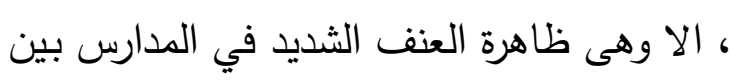

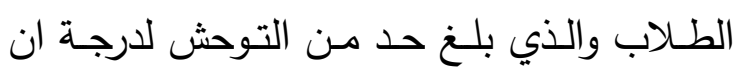
العالم تعامل معـه باسم توصيفي جديد وسماه "

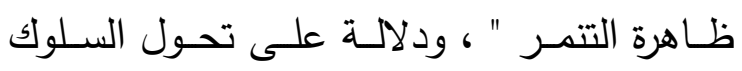

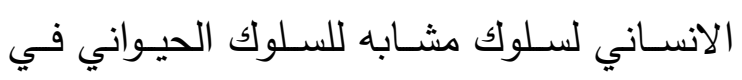

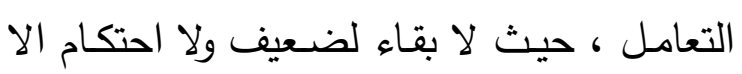

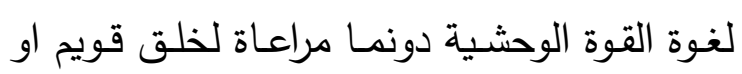

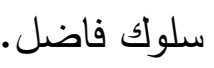
ولا ينفصل مجتمعنا العربي والاسلامي الان ولا نستطيع ايضا عزله عن المجتمع العالمي في لئي

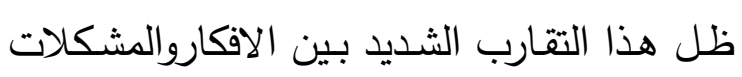
التي سرعان ما تجوب الكرة الأرضية في دقائق 


\section{ا انتشارأفلاج العنف:}

بتحليل مـا يراه الأطفال والبالغون من افلام وجد ان مشاهد العنف في الافلام قد زادت بصورة مخيفة وان الافلام المتخصصة في العنف الثديد

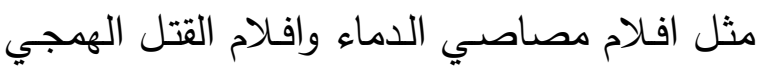

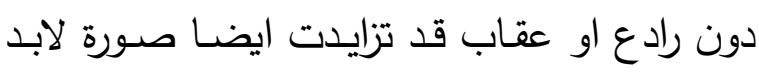

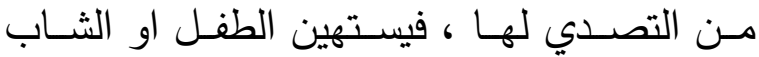
بمنظر الاماء ويعتبر ان من يقوم بذللك كما اوحي لتهي

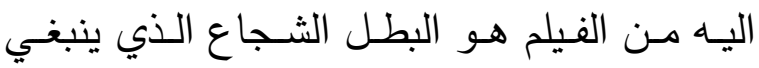
تقليده ، فيرتدون الاقنعة ( الماسكات) على الوجوه تقليــا لهـؤلاء - الابطــال - ويسـعون الـى شــراء ملابس تشبه ملابهم ويجعلون من صورهم صور

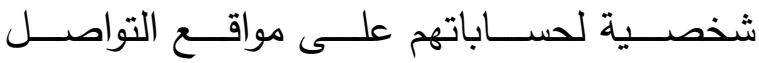

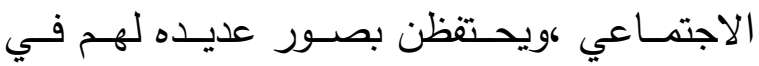

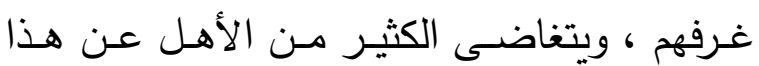
التقليد الذي يزيد من حدة العنف في المدارس او اوناون

الجامعات. (Bulach,et,al,2012:11)

\section{• افلام الكرتون العنيفة :}

لم تقتصر أفلام العنف عن الافلام الحقيقية التي يمثلها الممثلون بل وصلت الى مستوي افلام الكرتون التي يقضـي الطفل امامها معظم وقته

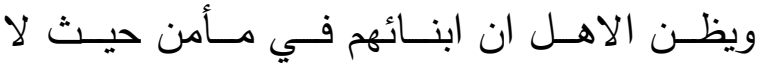
يشاهدون الا تلك القنوات ، والحق انها اخطر في توصيف تلك الرسـالة العنيفة حيث بتقبل الطفل الصغير الافكاربصورة اسرع من الكبار ، وحيث تعتمـد افلام الكرتون على القدرة الخارقـة الذائبـة والتخيلية عن العمل البشري في تجسيد أثر القوة

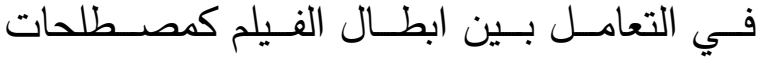
اسـتخدام السـحر وايـذاء انفسـهم بحركـة واحـدة
لكن المشكلة القائهـة الان تكمـن في امـرين ،

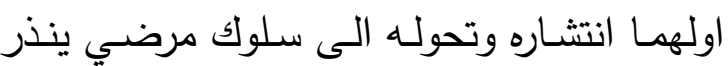
بخطورة شديده ، وثانيهما عدم مواجهته المواجهة التربويـة الحاسـمة التي تسيطر عليه وتحد من انتشـاره وتقلـل مـن آثاره ، ولهذا كان لابد مـن بحث وتحديد الأسباب التي ادت الى انتشاره ذلك الانتشار السريع والمريب وكان منها :

\section{ألعاب الالكترونية العنيفة :}

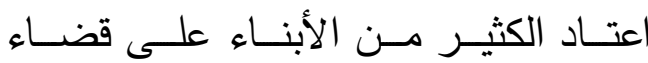

الساعات الطوال في ممارسة الالعاب الالكترونية العنيفة والفاسدة على اجهزة الحاسب او الهواتف

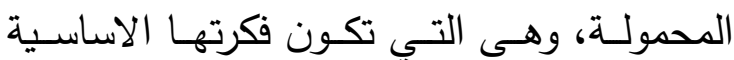
والوحيدة على مفاهيم مثل القوي الخارقة وسحق الفصول واستخدام كافة الاساليب لتحصيل اعلى النقاط والانتصـار دون أي هدف تربوي، ودون قلق مـن الاهـل علـى المستقبل النفسي لهؤلاء

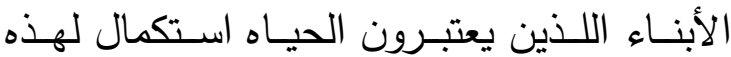
المباريـات، فتقوي عندهم النزعة العدائية لغيرهم الابـاه فيمارسـون بهـا حيـاتهم في مدارسـهم او بـين معارفهم والمحيطين بهم بنفس الكيفية، وهذا من

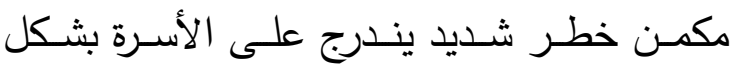

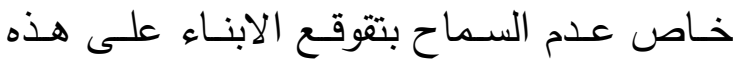
الالعاب والحد من وجودها، وكذلك على الدولة بشكل عام ان تتدخل وتمنع انتشار تلك الالعاب المخيفة ولو بسلطة القانون لانها تدمر الاجيال وتقتك بهم فلابد وان تحاربها كما تحارب دخول المخدرات تماما لثدة خطورتها.

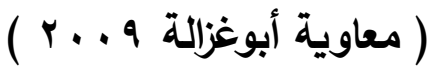


لتعيد الى الاذهـان منظر حلبات المصسارعة التي كانـت تقـام في المسـارح الرومانيـة في العصـور الوسـطي والتـي كانــت تتتهى دائمسا بمقتـل احـد المتصارعين من العبيد كوسيله من وسائل الترفيه البربريـة وقديمهم كطقوس دويـة متوحشـة لتسـبب سعادة مقطيه لهؤلاء المتابعين والغربب أن جمهور كبير من المتابعين لهذه القنوات من الفتيات في ملاحظة غريبة حول هذه الرياضـة التي ظلت فترة كبيرة هواية خاصة من هوايات الذكور لا الاناث ، مما اثر كثيرا على السلوك العام للفتيات المتابعات والذي ادى الى ظهور ظاهرة سميت " بالبو يات " وهـن الفتيـات المتشـبهات بالرجـال في سـلوكهن وتعـاملهن وبالتـالي تكونــت بـوره لظهـور التتمـر داخل الاوساط الطلابية للفتيات في المدارس •

(Bulach,et,al,2012:11) • العنف الأسري والمحتمعي: يطبع كل إنسان في مطلع حياته على مـا شاهده من تصرفات داخل بيئته الصغيرة كالأسرة وكـذلك علـى مـا يثـاهده يوميـا مـن تصــرفات مجتمعية ، كمن شاهد افعالا او ردود افعال تتسم بـالعنف بـين والديـه ، او مـن عـاش بنفسـهـ عنفـا يمارسه احد افراد الأسرة عليه هو شخصيا او على له أي احــد مـن المتعـاملين مــن الأســرة كالخـدم والمربيات والسـائقين، او من شـاهد عنفا مجتمعيا خاصة في البلاد التي ضعفت فيها القبضة الأمنية نتيجـة التوارث وغيرهـا وانتشـرت البلطجـة كوسيله مضمونه لنيل الحقوق او للاعتداء على الحقوق دون خشية عقاب رادع او محاسبة فعالهه ، فلابد

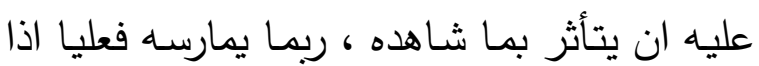

واسـتخدام المقويــات والمنشــطات والاســتعانة بأصساب القوة الاكبر في المعـارف ، كل هذه منتشـر وبقـوة في تلـك الافـلام الكرتونيـة والتي تساهم في ايجاد بيئة فاسدة يتربى خلالها الطفل على استخدام العنف كوسيلة وحيده لنيل الحقوق

او لبسط السيطرة.) Lipson, 2001, 62 ) • الخلل التربوي في الأسرة: تشــل بعـض الأسـر عـن متابعـة ابنائهـا سـلوكيا تعتبر ان مقيـاس ادائهـا لوظيفتهـا تجـاه ابنائها هو تلبيـة احتياجـاتهم الماديـة مـن مسكن وملـبس ومأكـل وان يـدخلونهم أفضـل المـدارس ويعينـوهم فـي مجـال الدراسـة والتفـوق وبلبــون حاجـاتهم مسـن المــال او النزهـــة وغيـره مــن المتطلبـات الماديـة فقـط، ويتناسـون ان الـدور الاهم الواجب عليهم بالنسبة للطفل أو اشاب هو المتابعة التربوية وتكوين السلوك وتعديل الصفات السيئة وتربيتهم التربية الحسنة، وقد يحدث هذا نتيجـة انشـغال الاب او الام او انشـغالهما معـا عن ابنائهمـا مـع القـاء التبعيـة على غيرهم مـن المدرسين او المربية في البيوت ، فربما نجد فعلا انحـراف الابـن او تشـوهه نفسـيا نتيجــة الخطـأ التربوي الواقع من أبويه.

( نايفة قطامه، منى الثريره جr: انتشار قنوات المصارعة:

لـوحظ في الفترة المـؤخرة تزايـد كبيـر في قنوات المصارعة الحرة العنيفة جدا التي تستخدم فيها كل الوسائل الغير عادية في الصراع ، والتي غالبا ما تتتهى فبسيلان دماء احد المتصارعين او كليهمـا في منظـر شـديد التخلف والعدوانيـة 
، والاهل الغافلون لا يشعرون بذلك ، بل قد يهاجم

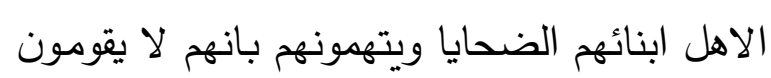

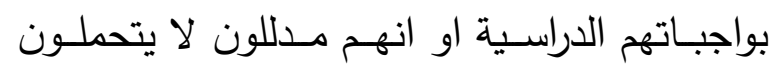

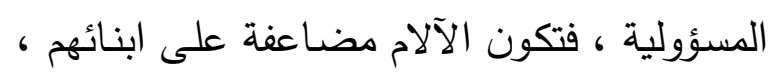

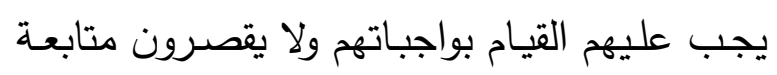

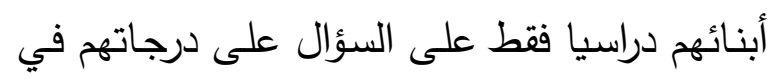
الامتحانات السنوية او الدورية.

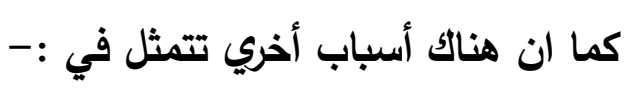

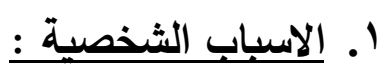

هناك دوافع مختلفة لسلوك التتمر ، فقد يكون

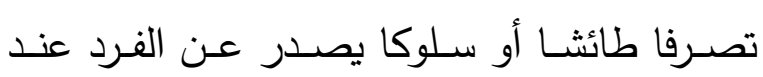

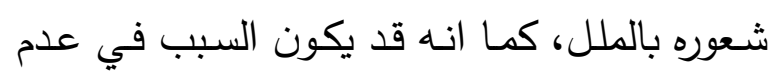

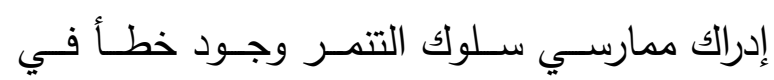
ممارسة هذا السلوك ضد بعض الأفراد، او لأنهم

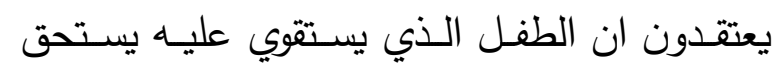

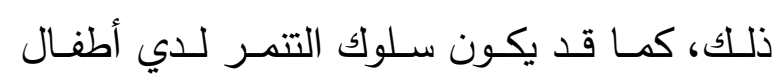

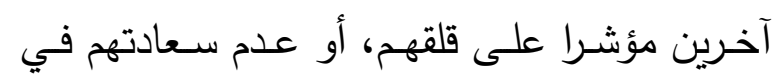

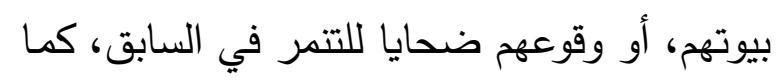

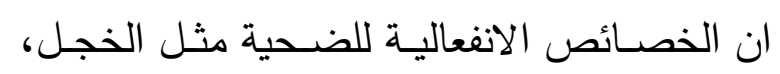

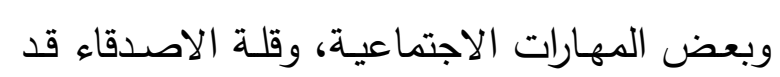
تجعله عرضة للتنمر • r الأسباب النفسية:

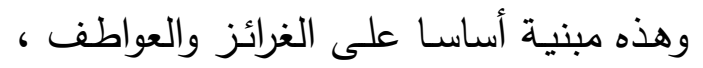

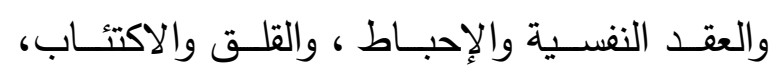

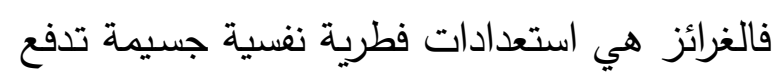
الفرد الى ادراك بعض الاشياء من نوع معين، وان

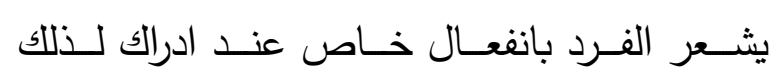

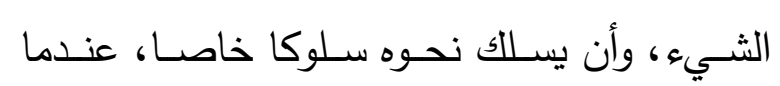

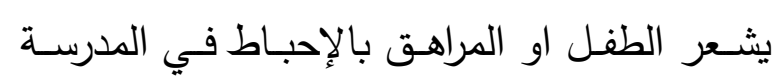

سنحت له الفرصة ، وهكذا يجنى المجتمع على

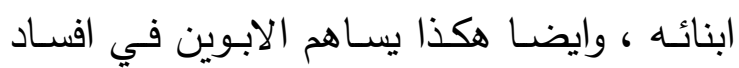

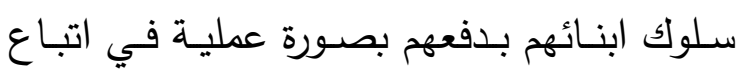

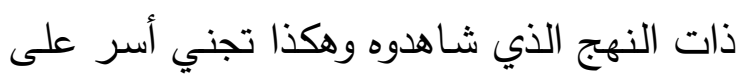

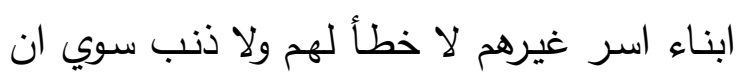

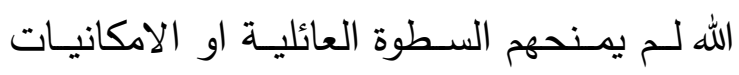

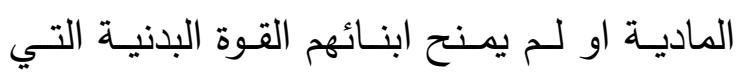

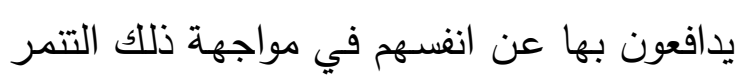

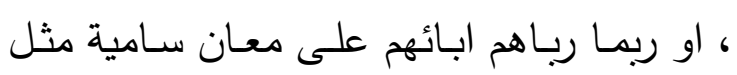

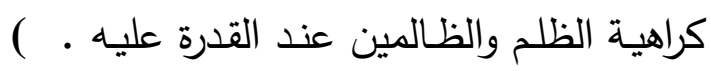
Strom, et al,.2013 ) اذا لابد على الأهل ان يراجعوا انفسهم جيدا

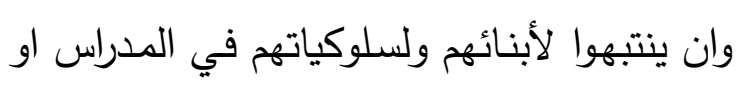

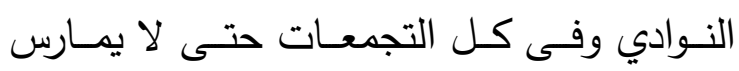
ابنائهم ذلك السبيل الشين ، وكذلك يجب على لـى لادي الهـربيين في المـدارس ان يـردوا تلـك الظــاهرة

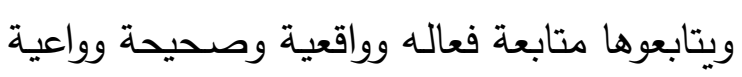

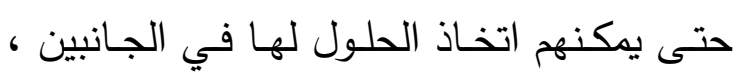

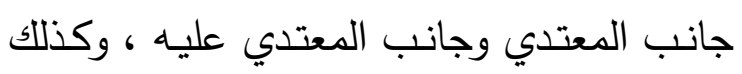

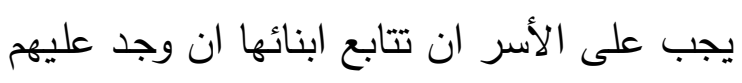

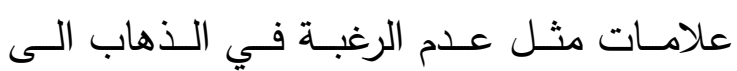

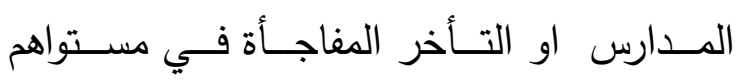
الدراسي او وجود آلام أو جروح او اصابات في الدفاري

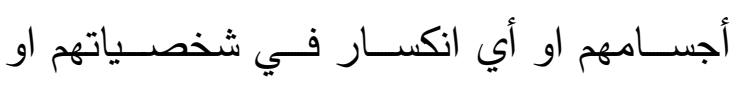

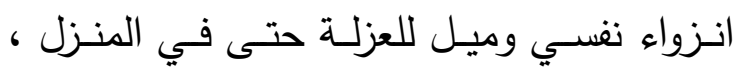
فيجب عليهم طمأنة ابنائهم وسؤالهم والاستفسار

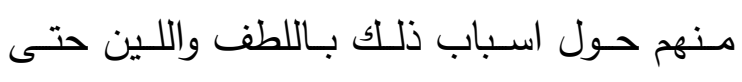
يتبينوا حقيقة تلك الاسباب ، فقد يكون ابنائهم قد داب داب

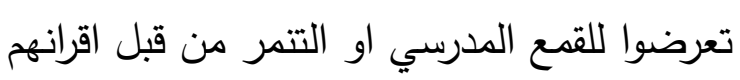


غيـر السـوية ، وضــف العلاقـة بـين المدرسـة والأهـل، والظـروف والعوامـل الأسـرية والمعيشـية

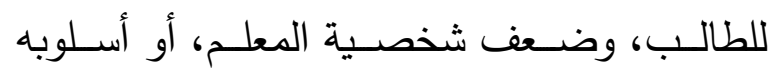
الدكتاتوري والتتميربين الطلبة ، وعدم إلمام المعلم بالمـادة الدراسية، كل هذه عوامل قد تسـاعد على

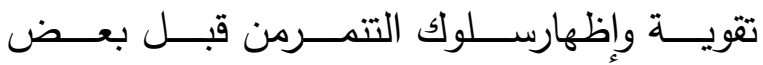
الطلبة(الشهريبr . . r) (عويدات وحمدي V9 99 ) )

كما ان العلاقات المتوترة والتغيرات المفاجئة داخل المدرسـة، والإحبـاط والكبـت والقهـع للطلبـة، والمنــاخ التربـوي الـذي يتمثل في عـدم وضـوح الأنظمـة المدرسـية وتعليماتهـا، ومبنـي الدراسـة، واكتظـاظ الصـفوف بـالطلاب، وأسـلوب التدريس غيـر الفعـال، كـل هـذه العوامـل قـد تـؤدي الـى الاحبـاط ، مـا يـدفعهم للقيـام بمشـكلات سـلوكية يظهر بعضـها على شكل تتمر ولا ننسي هنا في هذا المقـام أن نتحدث عـن جماعـة الرفـاق والتي تؤدي أدوارا متعددة على إثار السلوك التتمري أو هي تعزيزه فقد تقوي بعض الأطفال على غيرهم من الأطفال استجابة لضـط جماعـة الأقران ن ومن أجل كسب الشعبية، وهذا يظهر جليا في مرحلة المراهقـة، حيث يعتمـد المراهـق في تقديره لذاتـه،

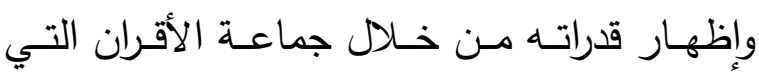
تلعـب دورا كبيـرا في النمـو الاجتمـاعي للمراهـق.

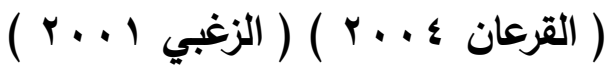

؛. أســباب مـــن وجهـــة نظـــر المتنمــرين والضحايا أنفسهم :
مـثلا عندما يكون مهمهلا ،ولا يجد اهتمامـا بـه وبشخصيته، ويصـح التعلم غايـة يـراد الوصسول اليها، وعدم الاهتمـام بقدراته وميوله ، فان ذلك يولـد لديـه شـعور بالغضـب والتـوتر والانفعـال لوجود عوائق تحول بينه وبين تحقيق اهدافه مما يؤدي الى ممارسـة سلوك العنف والتتمر ، سواء على الآخرين، او على ذاته لشعوره بـان ذلك يفـرغ ضــوطه وتوتراته، كمـا ان الأسـرة التي لتي تطلب من الطالب الحصول على مستوي مرتفع من التحصيل يفوق قدراته وامكانياته ، قد يؤدي كل ذللك الى الاكتئاب وتفريخ هذه الانفعالات من

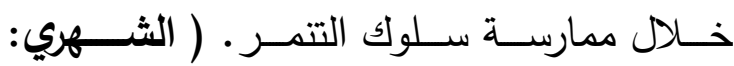

\section{$(r \cdot r$ r. الأسباب المدرسية:} وتشمل السياسـة التربويـة وثقافة المدرسـة ن والمحسيط المـادي والرفـاق في المدرسـة ، ودور المعلم وعلاقته بالطالب والعقاب ، وغياب اللجان المختصــة ، فـالعنف الذي يمارسـهـ المعلم على الطلبـة مهمـا كـان نوعـه ، لـن يقف عند حدود إيذان الطالب له سمعا وطاعة ، فلابد أن يدرك أن الاذعـان الظـاهري مؤقت يحمـل بـين طياته كراهية ، وينتشر ليكون رأيا عاما مضـاد لله بين طلبة الصف والمدرسة ، ومن المحتمل أيضا ان تصل الى درجة التتمر المضـاد ، سواء المباشر

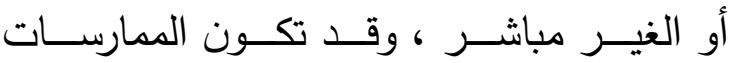
الاسـتفزازية الخاطئـة مـن بعـض المعلمـين وضــف التحصـيل الدراسـي للطالـب والتـأثير السـلبي لجماعـة الرفـاق والمـزاج والاستهتار مـن قبـل الطلبـة ، والخصـائص الشخصـية والنفسـية 


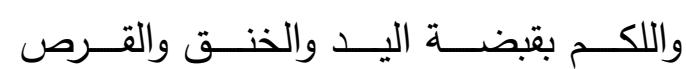

• والعض

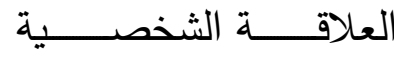

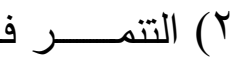

Relational Bullying

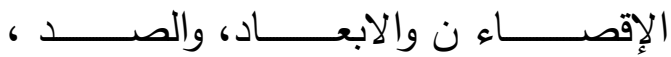

والاكاذيب ، والاشاعات المغرضة .

: Bullying Verbal التنمـر اللفظي

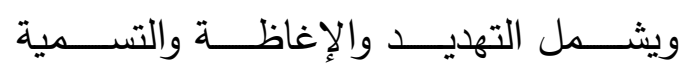

$$
\text { بأسماء سيئة . }
$$

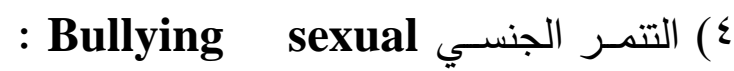

ويتمثل في سـلوك الملامسـة غيـر اللائقـة او المضايقة الجنسية بالكلام .

0) التنـــر الالكترونــي

Cyberbullying

المعتمــد والمتكـرر الـذي يلحـق بالضــية

مـن خـلال اسـتخدام أجهـزة الكومبيــوتر

والهواتـف المحمولــة والأجهـزة الإلكترونيـة

الأخرى . (Crabarion , 2003 ( )

ويعـرض جـون(John,2006) مجوعـة ·

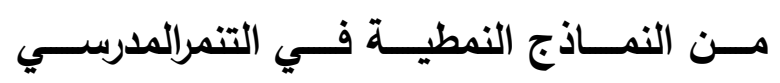

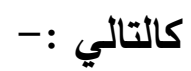

النمــــوذج الأول : التنمرالمدرسـي الفــردي وهو في حالـة متنمـرأو (Serial Bullying) معتــد وأحسـد يقـوم بايــذاء فـرد أومجموعـة مـن الأفراد وهذا النمط موجود بكثرة في المدارس.

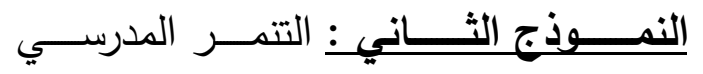

الجمـاعي غيـر المتجــانس عنـدما يقـوم أكثـر مـن متنمـر او معتـد بـالتنمر المدرسـي علـى
يمكن إجمال بعض الأسباب العامة للتنمر من وجهة نظر الطلبة المتنمرين والتى تجعلهم يتنمرون على الضحايا في الآتي : - التظاهر بانه شخص مهم . - لأنه ليس لديه أصدقاء يدافعون عنه . - لأنه علاماته سيئة فى المدرسة . لـ لـئ - لنه طالب متكبر على زملائه . - لأنه يتظاهر بانه شخص غني . - لأنه ينقل معلومات عن الطلبة للمعلمين - لأنه يتجاهل الطلبة الآخرين -

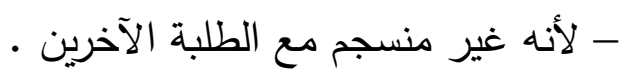
- لأنه تربط صلة قرابة بالمدير أو المعلم - لأنه يرغب بإظهار قوته أمام الآخرين .

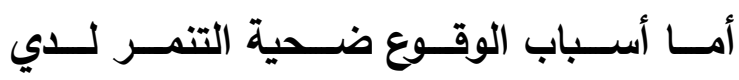
الطلبة الضحايا فيمكن إجمالها بما يلي :- الصمت الدائم وعدم التحدث مع احد .

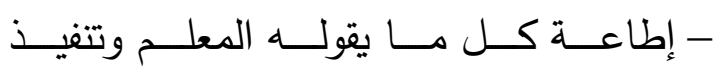
تعليماته وتوجيهاته .

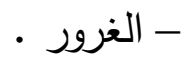
- اللباس والمظهر المتميز -

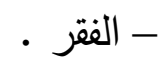

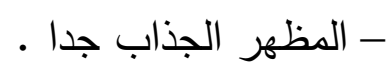

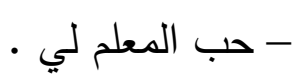
- كثرة الكلام والتذخل في ما لا يعنيني • - إحضار نقود كثيرة معي للمدرسة . * إنماط التنمر:

\section{Bullying}

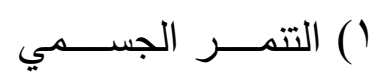

Physical 


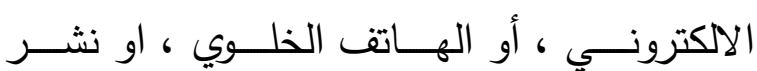

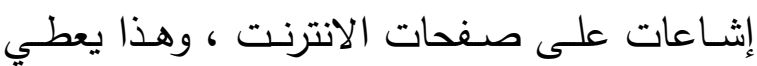

مساحة إضافية للتنمر • (Dickerson,2005) مـن هنـا نلاحظظ ان للتنمـر أشـكالا كثيـره ،

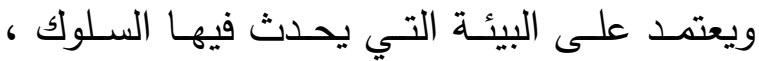
فبعض أشكال التتمر تحدث في المدرسة أو في مراكز الإصلاح ، وبعضها يحدث في بيئة العمل

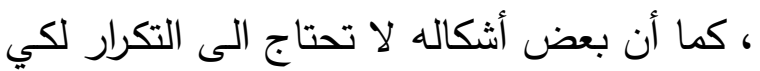

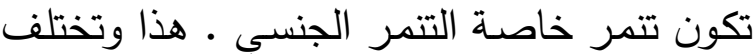
كلمة تتمر من بلد الى آخر ، حيث تلعب الفروق الثقافيـة دورا مهمــا في تعريـف المفهوم وأثـكاله

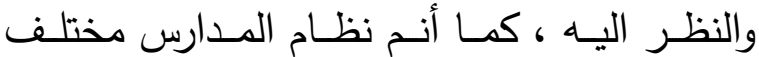
وكذللك دخـول الطلبـة الصف الأول ، وكذلك ان أدوات قيـاس وتقـدير التتمـر مختلفــة فهي تـارة ترشـــيحات الأقــــان ، أو تقـــارير المعلمــين وملاحظاتهم أو الاستبيانات ، او التقارير الذاتية . كما تختلف النظرة للفترة التي يتعرض فيها الطفل للتنمر وهكذا. (Wolke et al 2002) • مدي انتشار التنمر:

التتمر ظاهرة دولية تحدث في جميع المدارس ، ويختلف معدل انتشارها في المدارس من مجتمع

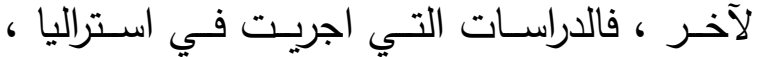
وانجلترا ، وكندا ، وغيرهـا تثـير إلى ذلك. ففي التي استراليا تختلف معدلات التتمر عن معدلاتها في انجلترا، وكذلك عن امريكا ـ وتشير الإحصائيات

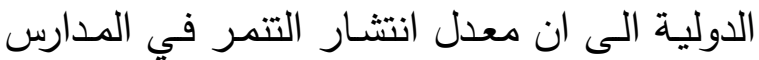
يتـراوح مـن • 1 - 10 \% وان معـدلات ضــايا التتمر تختلف من بلد لآخر • ففي اليابـان يبلغ

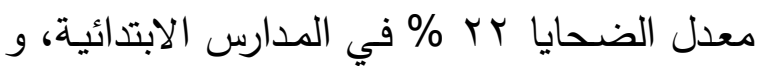

الضــية ، وهــو نــوع حــديث مــن التتمـر

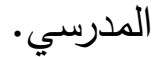

النمــــوذج الثالـــث : التتـــر المدرســي

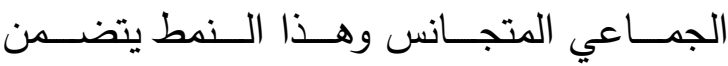
مجموعـة مسن الاطفــال المتنمـرين مـن نفـس العائلــة يمارسـون التتمـر الددرسـي علــ فـرد

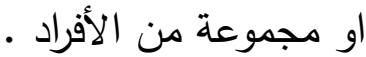

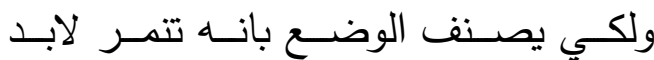

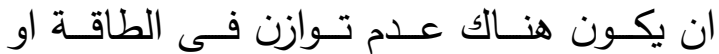
القوة ( علاقة قوة غير متماثلة ) ، بمعني آخر الطلاب الذين يتعرضون لأفعال سلبية يعانون بصفة عامة من صعوبة الدفاع عن أنفسهم، ولا

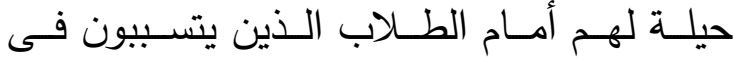
مضايقتهر ـ اما حينما ينشأ خلاف بين طالبين متساويين تقريبا من ناحية القوة الجسمية والطاقة

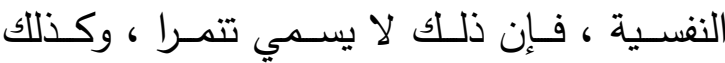

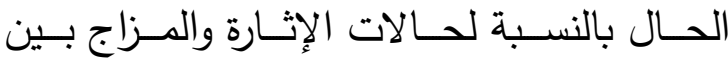
الاصدقاء ، غير ان المزاج الثثيل المتكرر ، مع

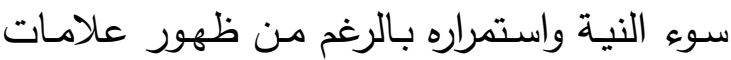
الضيق والاعتراض لدي الطالب الذي يتعرض الذبن

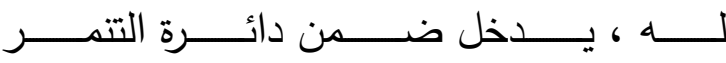

(Olweus,2005 ).

وعادة يحدث التنمر بعيدا عن الكبار كما في (ملعب الددرسـة ، أثنـاء الحصص لعص ، في

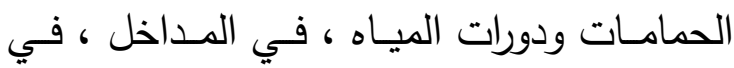
أمكان انتظار الباصـات و داخل الحافلات ، في الطريـق للمدرسـة ، كمـا يمكن ان يكـون التتمـر

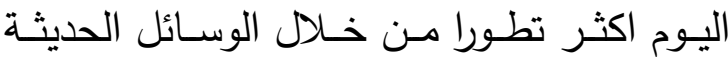
كالإنترنت مثل ارسال رسـائل عن طريق البريد 


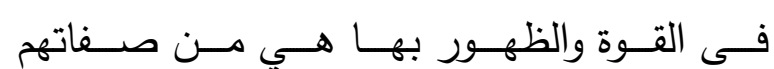

(atewin \& ah . 2001 ) .

وذكر كل من واردين وماكينون ان المتنمرين

تتقصــهم القــدرة علـى تقيـيم العواقـب الانفعاليـة لسـلوكهم تجـاه الآخـرين ، والتعـاطف مـع مشـاهر

( Warden \& Mackinnon , . الآخرين 2003,369 )

ويوصـف المتنمـرين بـانهم أطفـال ومـراهقين

لديهم انماط سلوكية عدوانية ـ وبشكل أكثر تحديدا

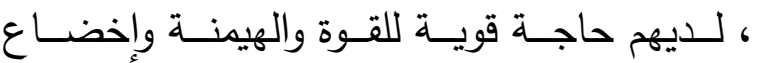
الآخرين ، الأمر الذي يبدو ممتعا بالنسبة للمتنمر بوصفه فى مركز سيطرة ـ كما أن لدي المتنمرين تقـــص انفعـال أقـلـل وضـبط انفعــالات أقـلـ، ويشعرون بالرضـا عندما يسببون أمسلا للضحايا ، لآنهــم ببسـاطة يختــارون غالبـا أطفـالا أصــر

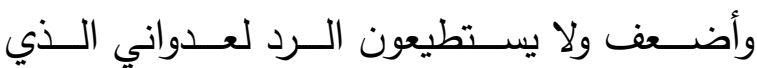
يتعرضون له. (Jordan \& Austin . 2012 ) واكد وونج ان المتنمرين يميلون الى السيطرة

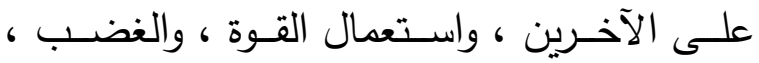
والانتقــام ، وعـدم الانضـباط ، ويظهـرون أفعـالا

وسواسية . ( Wong , 2009 , 98 ( ) ولقــ صـنف وونـج المتنمـرين السى نـوعين هما :

المتنمـرين العـدوانيون : وهـم اكثر شـهرة ،

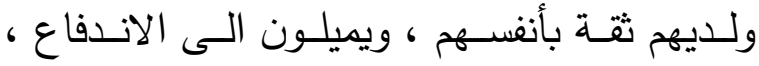
والقسوة ، والقوة ، والعنف ، ويعتقدون ان عدوانهم هو الطريقة الوحيدة للحفاظ على ذواتهم قوية وحل

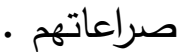

با \% فـي المـدارس المتوسـطة، و ج\% بـين طـلاب المــدارس الثانويــة، بينمــا يبـــن معـدل الضـحايا في مدارس انجلترا إلى حوالى • ب \% تقريبا. وتشير الدراسـات في استراليا الى ان كل تلميذ من بين ستة تلاميذ يتعرض لأعمال التتمر بطريقة أخري، مرة على الأقل كل أسبوع، ونظرا لـنتص الدراسـات والبحـوث عـن التتمـر فـي المدارس العربية، فإنـه لا توجد إحصـائيات عن

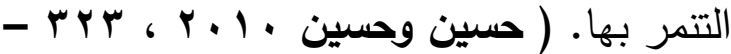
إلا ان الواقع يثـير الـى ان أحداث التنمـر أصبحت منتشرة في المدارس العربية بشكل يفوق مـا كانت عليه منذ سنوات قليلة ، وفى مصر أصبحت التتمر في المدارس الحومية بوجه عام والمدارس الخاصـة بوجهه خـاص ظـاهرة مدرسية بارزة .( شوقي 1999 ، 79 ؛ ) خ خصائص الطلاب المتنمرين وأنماطهم: أشـار أولـيس إلـى ان خصـائص الطـلاب المتنمرين بانهم مهيمنون على الآخرين ويحبون الثـعور بـالقوة ولكنهم ودودون مـع أصـدقائهم . ويري الباحثون ان الرغبة فيى القوة هـى السبب فى عملية التتمر وهذه الرغبة تعززت من خلال الأفكار والثائعات حول التنمر وادوار المؤسسات الإعلاميـة والأفـلام التي تصـور قدرات البطـل ومهاراتـه العاليـة ـ ومـن سـماتهز كذذلك القسـوة ولديهم أفكار لا عقلانية . ( Roberts . 2005 ( ) ويـري سـتيون ومـاهي ان القوة هـي السـمة الأبرز لدي الأطفال المتنمرين والسيطرة والرغبة 
وحينهـا سيفشـل المراهـق فـي لفــت انتبـاه

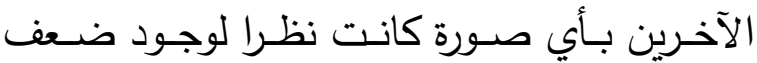

مهارة الاتصـال بهم وعجزه عـن إقامـة علاقـات اجتماعية معهم ، فتنحصر حجم شبكة العلاقات الاجتماعية لايه وضعفها ، وتدني مستوي الدعم

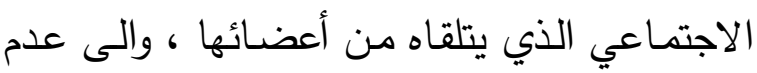

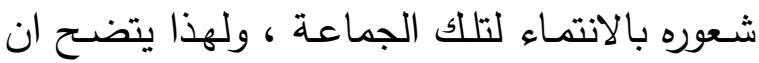

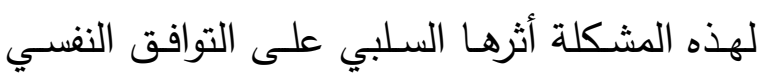
والاجتماعي للفرد ، كما تعد مؤشرا للمعاناة النفسية لإنية والاجتماعيـة التـي تـؤثر في تثـكيل شخصـيته وسلوكه . (محم عادل ، صد 191 ).

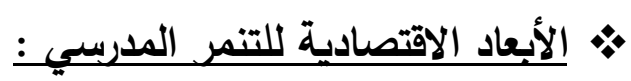
إن ممارسـة العدوانيـة تجـاه الممتلكات العامـة

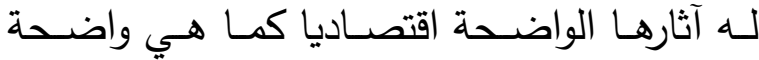

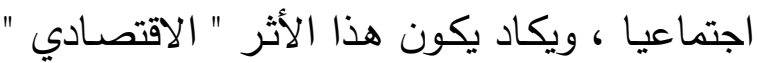
هو الذي يزعزع استقرار المجتمعات مالياً ، لآن

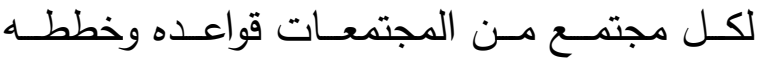
الاقتصـادية التي يسير عليها لتتقدم المجتمعات وتتمو وتزدهر ، ولكن عندما تقابل هذه الخطط بعراقيل تقف دون تقدمها بـل تسـاهم في عودتها

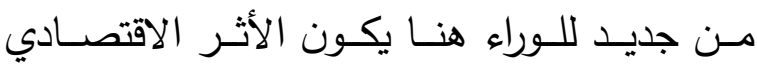
واضحاً للغاية .

فالممارسات العدوانية تجاه الممتلكات العامة تؤدي بصورة أولية الى هدر المال العام وتأخير

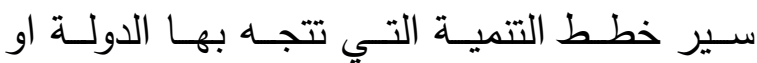
الحكومة الى تطوير المجتمع ومرافقه التي يستفيد منها الفرد بالدرجة الاولى ، فعندما تكون الدولة قد وضعت خطط تنمويـة معينـة وتقدر بمبالغ مالية

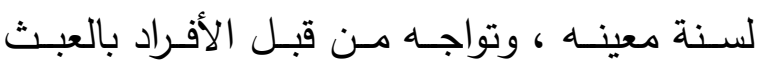

المتنمرين السلييون : وهم الذين يعززون ســلوك المتتمـرين العـدوانيين ، ويبـدؤون فـي المشاركة بشكل نشط بعد حدوث التتمر ، ونادرا

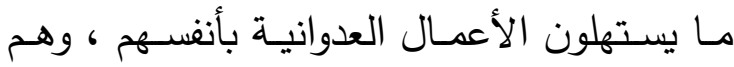
مخلصون وأوفياء للغاية للمتتمرين العدوانيين . ) Wong , 2009, 91 ) ومن هذا يتضـح ان المتنمر هو الثخص الذي يتمتع بالقوة ويري المتعة في ايذاء الآخرين الأقل قوة منه ، كما انه لا يراعي عواقب فعلته. • الأبعاد الاجتماعية للتمر المدرسي :تتزايد المشكلات النفسية والاجتماعية لدي

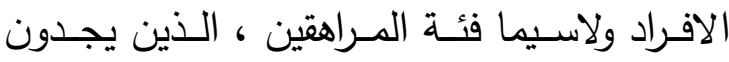
صـوبات كبيره في التكيف ، وإقامـة علاقـات

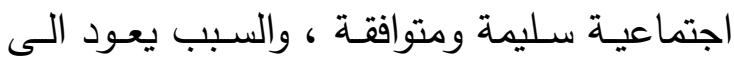
حساسـية هـــه المرحلـة العمريـة كونهـا مرحلـة

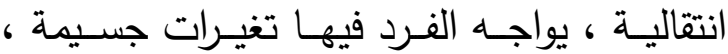

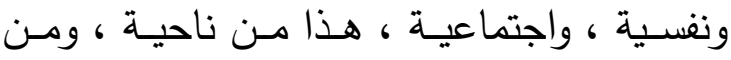

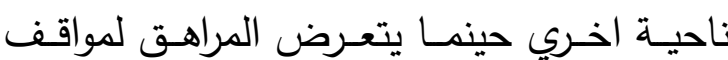

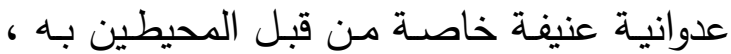

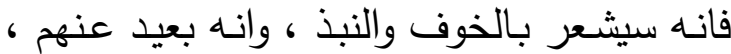

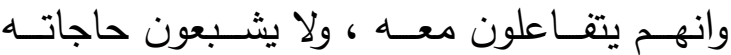
الاجتماعية المختلفة ، فيؤدي ذلك الى العديد من المشكلات والأعراض المرضـية ، ومـن أبرزهـا العزلة ، والانطواء والانسحاب ، والتي تعد سلوكا

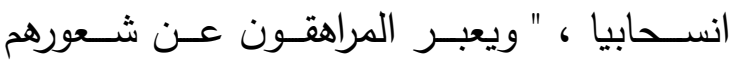
بالعزلة بأساليب مختلفة مثل الانسحاب ، الخوف

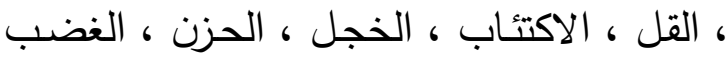
، وغيرها " ( اسماعيل الحمد ، صد؟ب ) . ل 


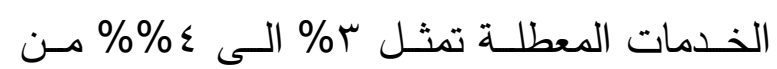
إجمالي الناتج المحلي ، أي ما يمثل خسارة تقدر بـ 11 مليـون دولار يوميـا ـ ( حسـين رشــوان،

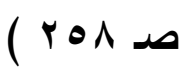

وكما أدت هذه الأحداث الى تداعيات سلبية

على سبيل المثال : المجتمـع الليبي حيث دمرت فيه البنيـة التحتيـة ، والممتلكات العامـة والخاصسة وتزايـد أعـداد المهجـرين والنـازحين والمتضـررين وتأخر صرف المرتبات لشهور طويلهـه وتم اغلاق بعض الحول والموانئ النفطية وتوقف فيها انتاج وتصدير النفط ممـا أدي الى انخفـاض معدلات

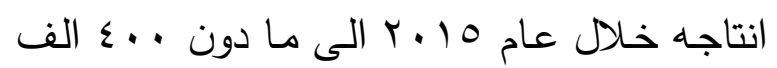

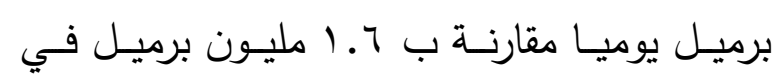

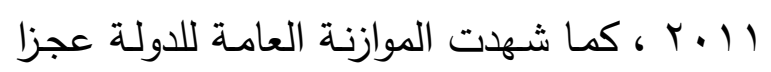
متزايدا دفع الحوكة الى الاقتراض لكي تتمكن من

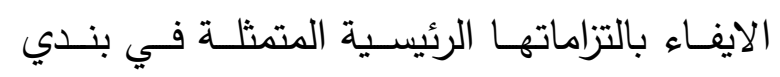

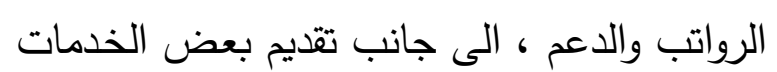

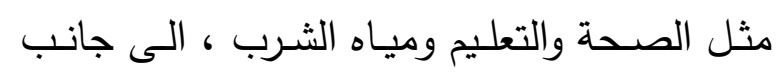
تغطية الخسائر التي نتجت عن خروج الشـركات النفطية الأجنبية التي جاءت للاستثمار في البلاد وأبرمت عقود عمل مـع الحكومة الليبية السـابقة ، وبعد ان دخلت البلاد منحدر الحرب خرجت هذه

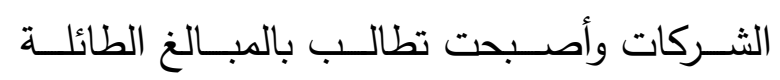
لاسترجاع معداتها داخل تلك الثركات في البلاد ، وغيرها من الآثار التي عكستها الأحداث السياسية وتغييـر الحكم في ليبيـا على جميـع المسـتويات وحرق مطسار طـرابلس الدولي الذي يعتبر بوابـة

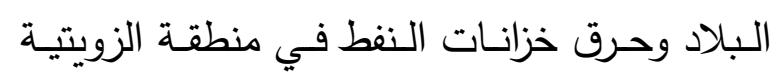

بـالمرافق والامـاكن العامـة هنـا يحدث نـوع مـن

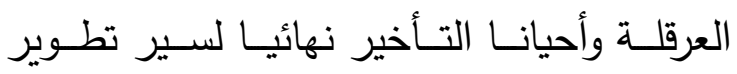
وإصـلاح هـذه المرافق ، فتـأخر الخطـط ماديـاً وزمنياً ليتأخر بها كذللك مستوي الخدمات التي هي يستقيد منها الفرد ، بمحاولة إصلاح العبث الذي خلقه السلوك العدواني مثل، الطرق ، المدراس ، امـاكن الترفيـه .....وغيرهـا . . مصـطفي ســالم

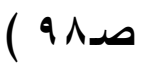
وعـى سـبيل المثـال لا الحصـر الثـورات العربيـة مثل الثورة في جمهوربـة مصـر العربيـة ومالها من آثار ونتائج على كافة المجالات منها الاقتصـادية والاجتماعية ... وغيرها ، فقد حدر

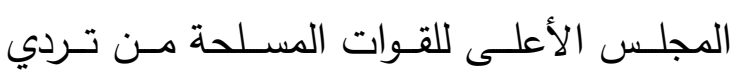

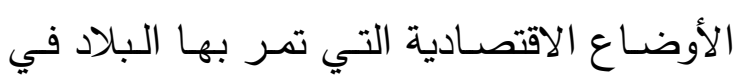

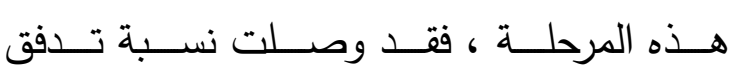
الاســتثمارات الـى الصــفر ، وتراجــع الـدخل

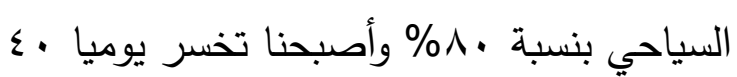
مليون دولار أي مـا يقرب من بـ مليون جنيه

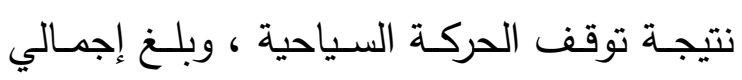
الدين المحلي والخارجي الى . ـ • ا مليار جنيه يمثل • 9\% مـن إجمالي النـاتج المحلي ، ومن ولن

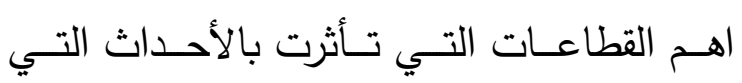
صاحب هذه الثورة او الحركة من اعمال عنف

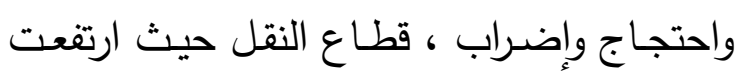
الخسائر الى 10 مليون جنيه يوميا ، وأثـارت

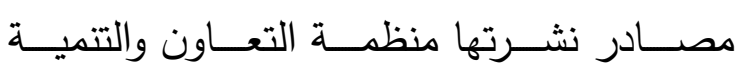

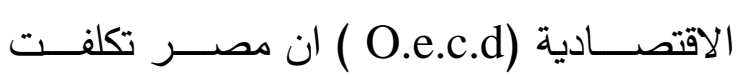
خسائر تقدر بـ • 9 مليون دولار بسبب قطعها

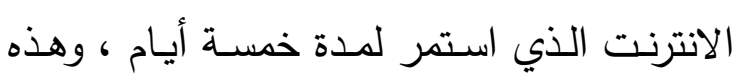


- إن ممارســــة العدوانيــــة والإســـــاءة الت تصـاحب للممتلكـات العامـة ينتج عنـه نظـره سـلبية تجـاه ممـارس هـذا السـلوك مـن ابنـاء مجتمعـــهـ ومسـن الــزوار الــذين يقصــدون مدينته . - مد

- تـؤثر ممارســـة هــذا السـلوم علــى تــنـي المسـتوي الثقـافي والفكري لأبنـاء البــد الـذي تكثر فيـهـ هـذه الممارسـات العدوانيـة خاصــة على الأماكن الأثرية منها أو التاريخية . ـــــنـي مسـتوي المكانــة الاجتماعيــة للأسـرة والتـي وضـعها المجتمــع فـي قاعـدة الهــرم مـن ناحيـة انـه يعـول عليهـا المجتمـع وعلى كـى التشــئة التي تحـوي قيم وثقافـة وقـوانين هـذا المجتمـع وتربيـة الابنـاء عليهـا ، ومـن بينهـا غـرس حـب الـوطن فـيهم والمحافظــة على

$$
\text { ممتلكاتهم العامة . }
$$

- عنــدما لا تقــوم بمعالجــة العدوانيــة تجــــاه الممتلكـات العامـة فـإن هــذا الفعـل سـوف توف يميز بـه أبنـاء المجتمـع ويصـبح ثقافـة حوار

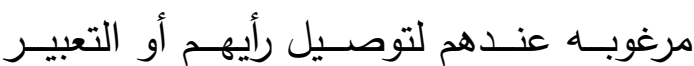

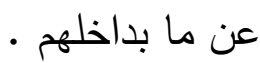

- ممارســة العدوانيـة تجـاه الممتلكــات العامــة

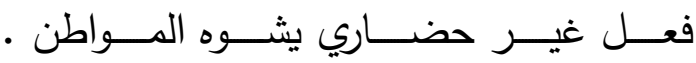

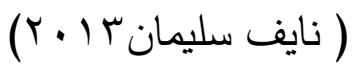

\section{ثانياً: مشكلة الدراسة :}

تعد مشكلة التنمر في المدارس الثانويـة مـن المشـكلات الخطيـرة التي تهدد الامـن المدرسي بأسرة لأنه يؤذي الطلبة جديا ونفسيا ويعمل على اشـاعة الفوضـى وعرقلة عمليـة التعليم ، وبـالرغم
شـرق البلاد والتي هـي قوت الليبيين ومصـدر معيشتهم • ( عبد الإله ، صد rV ) وفى ضـوء مـا سبق يعطينـا الدليل القاطع على ان عمليـات التخريــب والتـدمير تظهـر اقتصـاديا في أثرهـا الواضـح والجلي على خطط الدولـة ومشـاريعها التمويـة واتجاهاتهـا وسـرعة

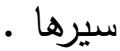
الأبعاد الثقافية للتنمر المدرسي : لو تمعنا كلمـة ثقافة لوجدناها كلمـة عربية عريقة ، تعني صقل النفس والمنطق وتقف نفسـه أي صـار حاذقـا خفيفـا فطنـا ، والثقافـة لا تعـد مجموعة من الأفكار فحسب ، ولكنها نظريسة في السـلوك ممــا يسـاعد على رسـم طريـق الحيـاة

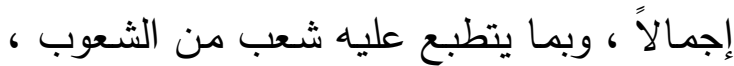
وهى المميزة لمقومات الأمه التي تتميز بها عن غيرهـا مـن الجماعـات بمـا تقـوم بـهـ مـن القيمي والعقائـد وهـى كـل مركـب يتضـــن المعــارف

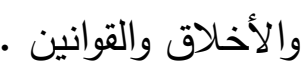
فالثقافـة التـي ينشـأ عليهـا الفـرد لهـا دور كبير في تنمية العنف والعدوانية مثلها يكون لها الأثر الواضـح مـن هـذا السـلوك ، فــن خـلال تشـيع الأسـرة مثثلا على العنف والعدوان واخذ

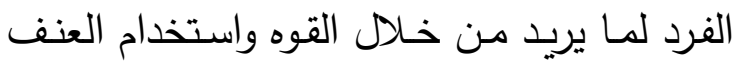
فهي بهذا الدور تجعل من ابنائها محط استهجان ونفـور الآخـرين مـــهم بـلـل وقلـة ثـــة المجتمـع واعتماده عليها في تربية الأبناء وتتمية سلوكياتهم الصحيحة .( غازي شريف ، أع) ومسن بـين اهـم الابعـاد الثقافيـة التـي يخلفها التنمر المدرسي الآتي :- 
تعـاملاتهم ، انهـا صـورة ضـحية اخـري مـن نـوع

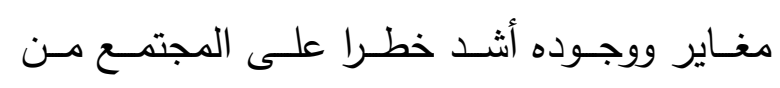
الصــورة الأولـى ، فكلاهمــا ضـــية ، وكلاههــا يحتـاج الى العـلاج النفسي والسـلوكي ، وكلاهمـا لابد من تخليصه من ذلك الضرر، وخاصسة انهما

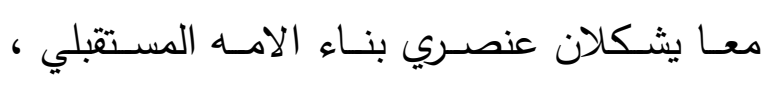
فالمعتدي والمعتدي عليه عضوان أساسيان في كل المجتمعات ، وإذا أهملنا الطفل المعتدي ولم نقومه وليه - تربويا وسلوكيا - سنعرض اطفال اخرين للوقوع في نفس المشكلة ، وسيسـاهم هذا فى استشـراق

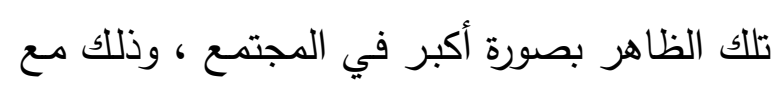
ضـرورة صــ جـل اهتمامنـا على الطفل الضـحية الذي وقع تحت اهمال الكثيرين. وترتكز مثكلة البحث الـراهن في التعرف علـى الابعـاد الاجتماعيـة والاقتصـادية لظـاهرة التنمر لاي طلاب مرحلة الثانوية. ثالثاً : أهمية البحث: ائ تنطلق أهمية البحث من الاهمية العلمية لهذه الظاهرة في انها تعد من الدراسـات الوصفية التي تهـتم بتتـاول الابعـاد الاجتماعيـة والاقتصـادية لظاهرة التتمر الدراسي بين طلاب المرحلة الثانوية من جميع جوانبها كما انها تولى اهتماما بالدراسات لهن التي تهتم بدراسـة التنمر والتصـدي لهـه الظـاهرة

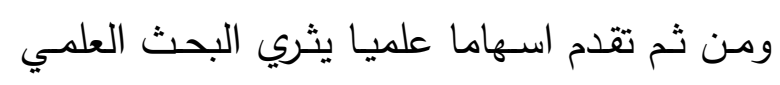

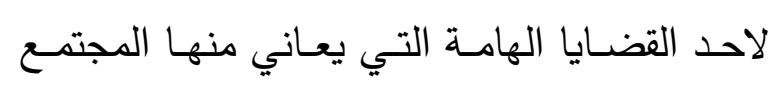

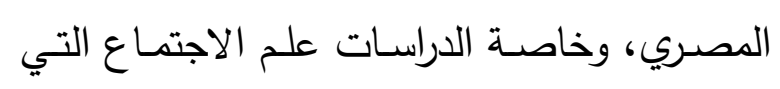
تهتم بدراسـة مشكلات المجتمع . كما تعد وسـائل وهاهي الاتصسال والدور الذي تلعبه في تحريض الطلاب

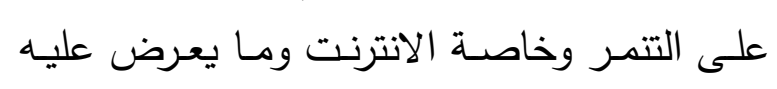

من ذلك لا يوجد اهتمام كبير بهذه المشكلة من

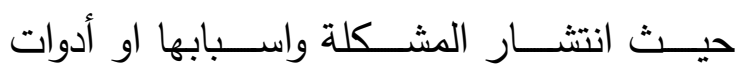

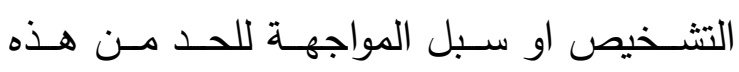
الظاهرة. ربمـا لا يشعر الكثير من الآباء والامهات او من المسؤولين التربويين في المدارس بمدي لاسي

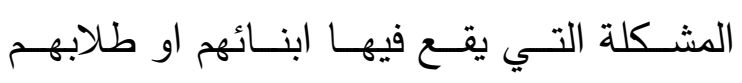
كضحايا للتنمر الا بعد فترة طويلة نسبية، وذلك

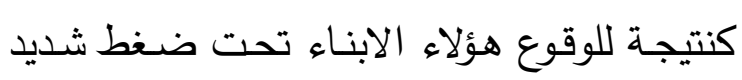

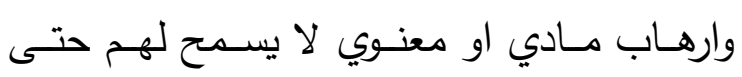

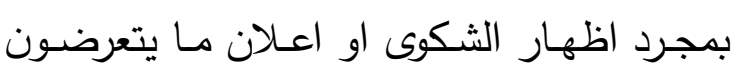
لهم حتى لا ينالهم مزيد من الذي على يد هؤلاء المتتمرين. ولا تقتصـر تلــك المشـكلة علـى صـفوف ومدارس البنين فقط - رغم شيوعها النسبي فيها - الا انها موجوده ايضا في مدارس البنات ولكن بحدة وصسورة تناسـ شخصياتهن، وتكون فيها الفتاة الضحية أكثر تحمـلا وأكثر استعدادا لكتم مـا تعانيه نظرا لطبيعـة الانثويـة الضـعيفة - في الضي بنات جنسهن جميعا - اللاتي حباهن الله بها.

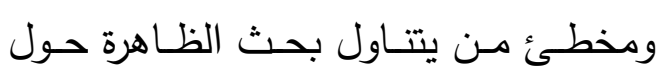

كونها فقط مشكلة للضحية الواقع عليها الضرر فحسب ، فلمشكلة صورتان مؤثرتان تأثيرا شديدا

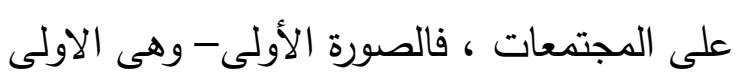
بالطبع بالاهتمـام وبالعلاج وإيجاد سبل الحل -

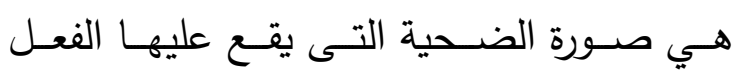

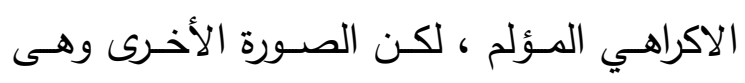
صـورة الطفـل او مجموعـة الطـلاب المتتمـرين اللـين يتخـذون صـورة العنفـ سـلوكا ثابتـا في 
خامساً : أسئلة البحث:

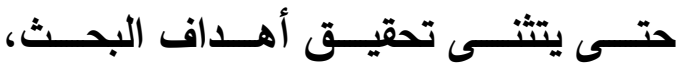

تسعي الباحثة للإجابة على الأسئلة التالية:

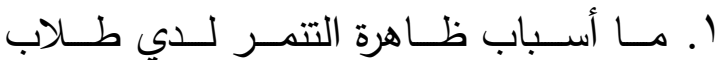

المرحلة الثانوية ؟

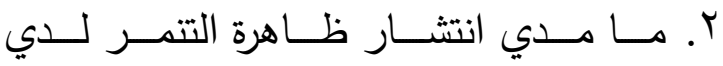

طلاب المرحلة الثانوية ؟

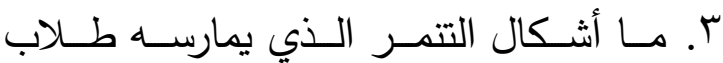

المرحلة الثانوية ؟

ع. مــا دور التكنولوجيـا الحديثـة فـي انتثــار

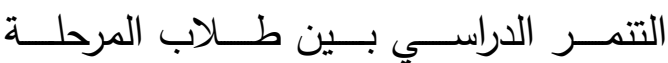

الثانوية ؟

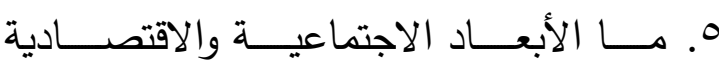

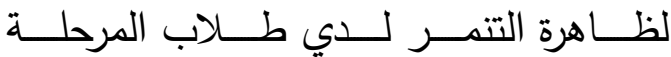

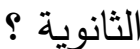

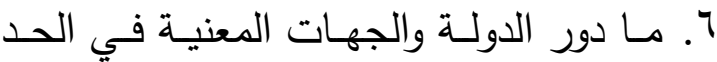

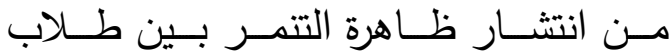

المرحلة الثانوية ؟

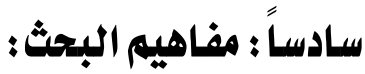

يعـد ألـويس ( Olweus ) مـن أوائل مـن

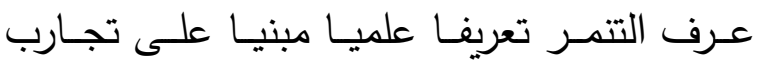

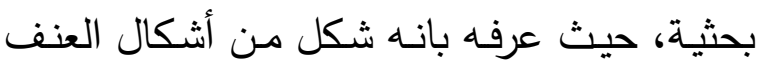

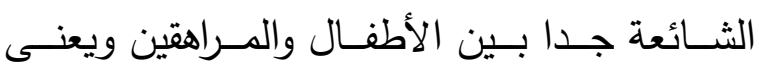
التصرف المتعدد للضرر أو الإذعان من جانب التبن

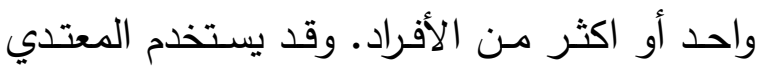

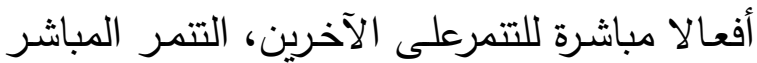
هـو هجمـه مفتوحسه على الآخـرين، مـن خـلال العدوان اللفظي او البدني، والتتمر الغير مباشر هو الذي يستخدمه الفرد ليحدث اقصـاء اجتماعيا
من أفلام الآكشن والرعب فضـلا عن الالعـاب الرياضية والالكترونية الخطرة او العنيفة وكذلك الرسوم المتحركة التي شجع على العنف حيث

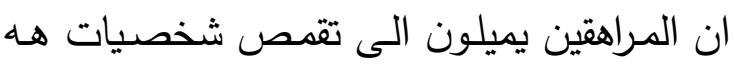

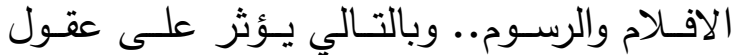

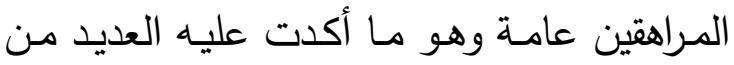
الدراسـات ان هنـاك ارتبـاط ايجـابي قويـا بـين وسائل التواصل الاجتماعي وبين انتشار ظاهرة التنمر الدراسي لدي الطلاب. رابعاً : أهداف البحث :

يســي البحــث للتعـرف علــى الابعـاد

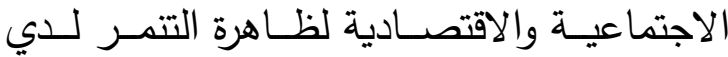
طلاب المرحلة الثانوية في مدينة المنصورة وذلك من خلال الاستعداد لتحقيق الأهداف التالية:-

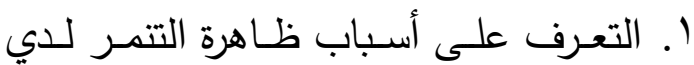

طلاب المرحلة الثانوية. r. التعـرف علــى مـــى انتثـــار ظـــاهرة التتمر لدي طلاب المرحلة الثانوية.

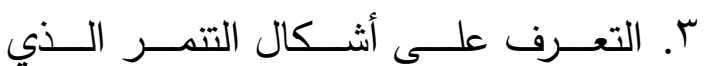
يمارسه طلاب المرحلة الثانوية. ؛. التعـرف علـى دور التكنولوجيـا الحديثـة

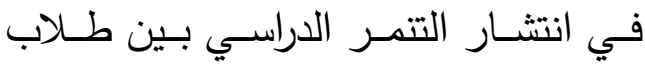

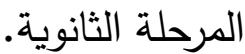

ه. الكثــــ عــن الأبعـــاد الاجتماعيــة والاقتصـادية لظـاهرة التتمـر لـدي طـلاب المرحلة الثانوية. ج. التعــرف علــى دور الدولـــة والجهــات

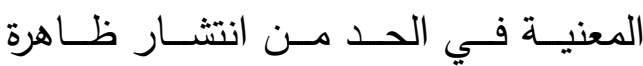
التتمر بين طلاب المرحلة الثانوية. 
يحـدث عنــدما يتعـرض طالــب بشـكل مكـرر لسلوكيات او افعال سلبية من طلبة آخرين بقصد إيذائه ، ويتضمن عادة عدم توازن في القوة وهو امـا ان يكـون جسـيا كالضـرب او لفظيـا كالتتابذ بالألقاب او عاطفيا كالنبذ الاجتماعي او قد يكون إساءة في المعاملة ( قطامي والصرايرة ، 9 . . ب : (ro

\section{وعرفه ملحم (r..}

هـو سـلوك عـدواني نحـو شـخص بهـدف

مشـاهدة معانـاة الضـحية مـن الألآم الجسدية التي

يتركها المعتدي عليه ( ملحم ، ع. . ب : 10 )

\section{كما عرفه هيونر ( Huebner . 2002 (}

بانـه طريقـة للسـيطرة على الشـخص الأخـر وهــو مضــايقة جســية او لفظيــة مســمرة بـين شخصين مختلفين فى القوة يستخدم فيها الشخص الأقوى طـرق جسـدية ونفسـية وعاطفيـة ولفظيـة

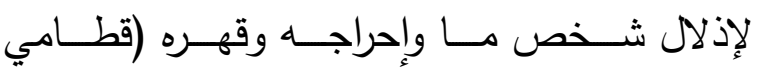

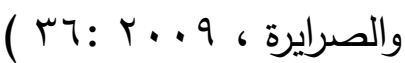
ويعرفه ديهان

بانه سلوك يتضمن السخرية وسرقة النقود من الضـحية واســاءة بعـض الطلبـة لأقـرانهم داخـل الصف ، الذي يشـترك في بعض خصائصسه مـع خصـائص سـلوك العـدوان (قطـامي والصـرايرة ،

$(r \leq: r \cdot . q$ وعرفه ميلور

بانـهـ عنـف طويـل المـدي يقـوم بـهـ فـرد او

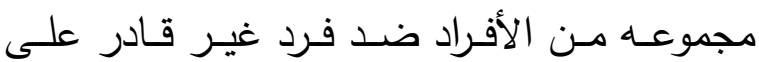
الـدفاع عـن نفســه وقـد يكـون جســيا او نفسـيا

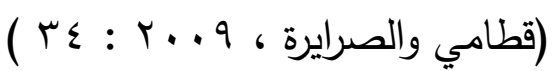

مثل: نشـر الثـائعات، ويمكن أن يكون التنمر غير المباشر ضار جدا على أداء الفرد مثله مثل التمر المباشر .(Olweus.1993:9 ويري ريجبي انهه عندما يتعرض طفل الى فعل او عمل ضار من طفل أكبر وباستمرار ، او عندما لا يكون هناك توازن بنهما في القوة نكون ماما حالة تتمر ( استقواء).. (Rigby, 2002 ( ماء) وفـى ولايــة فلوريـدا ( 99 ( ) يـري قسـم الامن المركزي ان التنمر ( الاستقواء ) هو شكل من اشكال العدوان الذي يقوم بـه شخص او عدة اشخاص بمضايقة أخر مرارا وتكرارا في الجانب الجسدي أو النفسي. ( فرنافا ع . . ب ) ويعرف هورورد وزملائه التتمر بانه سلوك يحـدث عنـدما يتعـرض طالـب تعرضـا مكـررا لسلوكيات أو أفعال سلبية من طلبة آخرين بقصد إيذائه، ويتضمن عادة عدم توازن في القوة وهو إما ان يكون جسديا كالضرب، او لفظيا كالتتابز بالألقاب، أو عاطفيا كالنبذ الاجتماعي، أو يكون

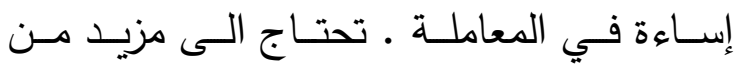
الايضـاح والتفصيل ولا سيما حول العلاقة بين

Horwood . ～مفهوم التنمر والعدوان (Waylen .Williams \&Wolke : 2005

$$
\text { وعرفه ( سليمان والببلاوي ، 1 . r ) }
$$
بانه هو : الهجوم من شخص مستأسد على شخص أضعف منه - لدية تلذذ لمشاهدة معاناة

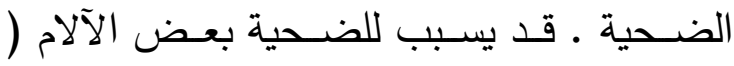

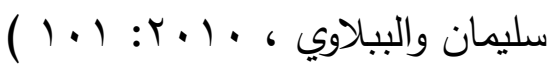
وكــذللك عرفـــهـ هـــــورورد وآخـــرون (Horwood etal , 2005 ) 
العربية وتعديلها حتى تكون للباحثين والباحثات على المستوي المحلي .

وطبقت الاستبانة مـن تصـيمها على عينة مـن أعضــاء وعضــوات الهيئـة المدرسـية فـي

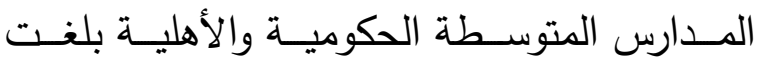

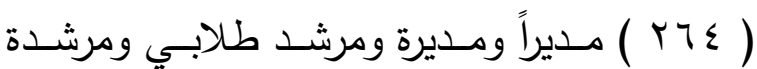
طلابية ومعلم ومعلمة ، وطبقت الاستبانة الخاصـة بدان لويس على عينة من الطلاب والطالبات في المــدارس المتوسـطة الحكوميـة والاهليـة بلغــت ( ) ع rq ) طالبا وطالبة ) وقـد أظهـرت نتـائج الدراســة انتشـار ظـاهرة التتمرفي المرحلـة المتوسـة بالمـدارس الحكوميـة والاهلية بمدينة الرياض بدرجة متوسطة .

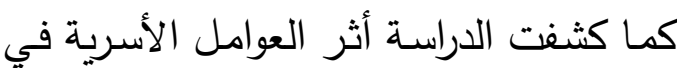
انتشار ظاهرة التتمر بين الطلاب والطالبات ، كما يـري أعضـاء وعضــات الهيئة التدريسـية والتـي تمثلـت في رأيهـم في أسـلوب التربيـة الخـاطئ غيـاب التوجيهـات الســلوكية الواضــحة ، النـزاع المستمر بين الوالدين ، عدم الاحساس بالأمان ...

امـا العوامل المدرسية فقد تمثلت في الافتقار الـى سياسـيات تأديبيـة وإجـراءات واضـحة تجـاه سلوكيات التتمر وضعف الارشاد الطلابي ...الخ. كمـا كشـفت نتـائج الدراسـة عـن خصـائص الطالـــب المتنمــــر وفـــق مرئيــــات الطــــلاب والطالبــات وهــــى الغـــرور بــــالنفس ، قـــوة الشخصــية ، والنظـــر للقــوة الجســدية علــى اســاس أنهـا ذات اهميـة خاصــة للحفــاظ علـى كلى الشعور بالقوة والسيطرة .
سادساً: الاراسات (لسابقة:

بالإضـافة الى الأبعاد النظريـة السـابقة فإن البحــث تتــاول عـدداً مــن الدراســات العربيــة والاجنبية التى تتاولت ظاهرة التتمر المدرسي أو المتغيرات ذات الصلة به . (الدراسات العربية : (الدية أ- دراســة نــورة بنـت ســد بـن سـلطان

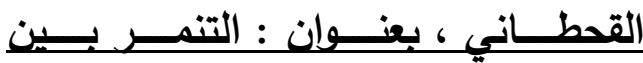
طـلاب وطالبـات المرحلـة المتوسـطة فيى مدينة الرياض ، 1 ، . ب .

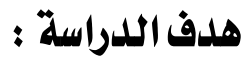

هـدفت الدراسـة الـى التعـرف علىى مـدي انتشــار ظـاهرة التتمـر بـين طـلاب وطالبـات المرحلــة المتوســـة فـى المــدارس الحكوميـة والاهلية بمدينة الرياض ، والتعرف على عوامل انتشـارها وخصـائص الطالب المتنمـر عليـه في المرحلـة المتوسطة ، وتحديـد انمـاط التنمر بـين الطلاب والطالبات المرحلة المتوسطة ، الجسدية وغير الجسدية ، والتعرف على آثار هذه الظاهرة على الطالب المتتمر عليه ، والاجراءات المتبعة فـي المرحلـة المتوسـطة بالمــدارس الحكوميـة

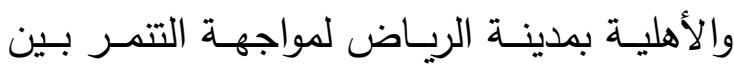
الطلاب والطالبات .

اسـتخدمت الباحثـة فـي دراسـتها المــنهج المسحي ، وقامت بإعداد استبانة من تصميمها غطت محساور الدراسـة ، كمـا استعانت الباحثة باسـتبانة البروفيسـور DanO'Lweus الرائـد العالمي المتخصص في مشاكل التتمر وضحاياه وذلك بشـراء الاستبانة منـه وترجمتهـا الى اللغـة 
تسـهم في التتبـؤ بـالتتمر المدرسـي لـدي عينـة الدراسـة التي اشتملت على (r Y Y) تلميذ وتلميذه مـن تلاميـذ الصـف السـادس بالمرحلـة الابتدائيـة بالمملكة العربية السعودية ز وأظهرت النتائج وجود

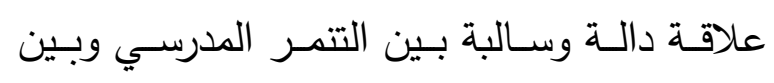
المهارات الاجتماعيـة ، كمـا أظهرت وجود فروق دئه دلالـه احصـائية بـين متوسـطي درجـات مرتفعي التنمر المدرسي ومنخفضـي التنمر المدرسـي كمـا بينت النتائج ان العوامل المهارات الاجتماعية التي

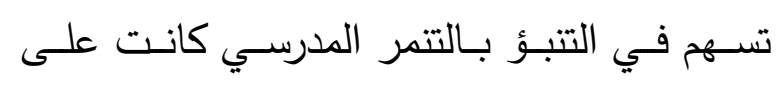

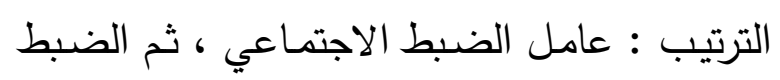
الانفعالي ، ثم الحساسية الاجتماعية .

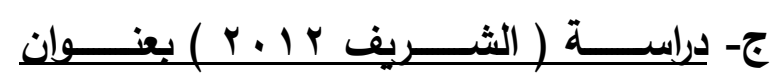

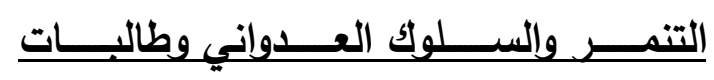
المرحلة الابتدائية .

حيـث هـدفت الدراسـة الـى التعـرف علىى الأسباب والأسـاليب التي تؤدي الى ظهور التنمر لدي الطفل سواء فى البيت او المدرسة ، وأظهرت النتائج أن التسـيب الاسـري والاتجاهـات العدوانيـة لدي الآباء تجاه الابناء تعمل على توليد التتمر لدي الاطفال من نفس البيئة الاجتماعية . وأوصت الدراسـة باشراك الوالدين بمجموعات تتعلـق بتربيـة الاطفـال ، وان يكـون هنـاك قواعد

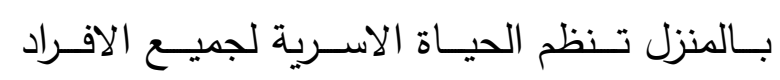
واجتناب العقاب الديني ، اما فيما يتعلق بالمدرسة أوصـت بتكثيف الأنشطة والمشـروعات الجماعيـة

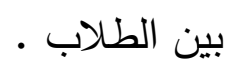

أمـا خصـائص الطالب المتتمـر عليـه مـن وجهة نظر الطلاب والطالبات فقد تمثلت في انه أصغر سناً وأضعف من زملائه، وتميز بسلبيته واستسلامه للمتنمر رغم تميزه الأكاديمي . وكشفت نتائج الدراسـة عن اختلاف انمـاط

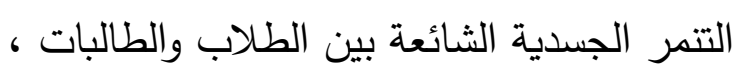

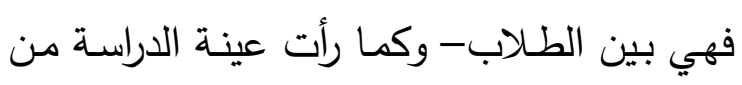
الذكور - بانها تتمثل في الضرب والركل والدفع والتجـاذب والحبس في إحدى حجـرات المدرسـة بالإضافة الى سرقة النقود . وبالنسـبة للطالبـات فتمثلـت أشـكال التنمـر الجسـدي- وكمــا رأت الطالبـات أنفسـهن - في لـي سرقة النقود أو بعض الممتلكات أو اتلافها .

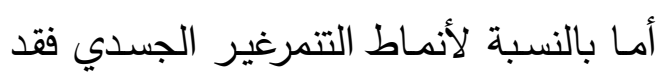

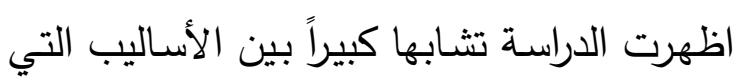
يسـتخدمها كـل مـن الطـلاب والطالبـات والتي

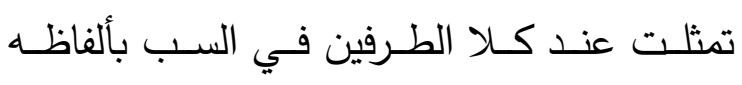
جارحة والسخرة والمضايقة بصورة مؤذيه والعزل بل بل

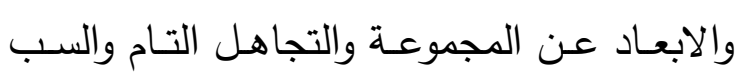
والتعليق بألفاظ جارحة بسبب اللون او الجنسية

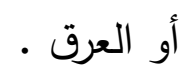

ب- دراســة ( حنــان خـوج ) بعنـوان التنمــ

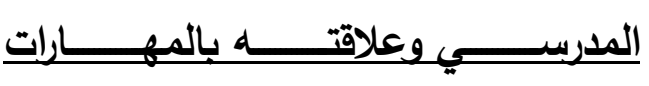

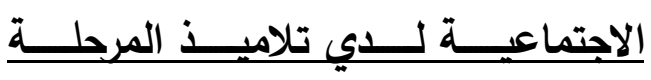

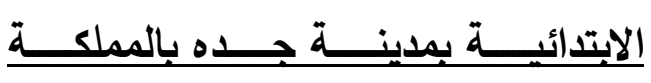

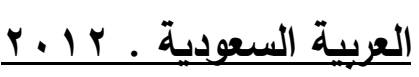
حيـث هـدفت الدراسـة إلـى التعـرف الـى الفروق الفرديـة بين مرتفعي ومنخفضـي التنمر المدرسي في المهارات الاجتماعية التي يمكن ان 
احالته الى الادارة ، والاتصـال بالأسـرة ، والعقاب البدني، والتجاهل والطرد .

وفيمـا يتعلق بالآثار الناجمـة على المتنمـر

عليه فقد بينت نتائج الدراسة تدهور الحالة النفسية والصـية ، قلـة الثقـة بالنفس ، الخوف ، القلق ، والهبه من المدرسة ، فقدان الضحية لتقدير الذات والـذي قـد يمتـد لمراحـل عمريـة لاحقـة وانعـدام التعاطف والاحترام والتقدير بين الطلاب والطالبات وهـذا بالإضـافة الـى مجوعـة مـن النتـائج التـي توصـلت اليهـا الباحثـة ، الا اننـا اكتفينـا بالنتـائج التي تهنا في دراستنا.

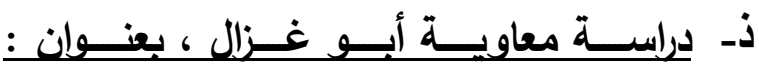

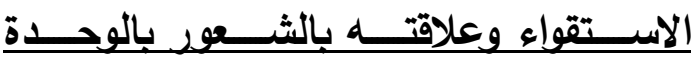

\section{والاعم الاجتماعي، 9 . . ج :}

هـدفت الدراسـة الحاليـة الـى الكثـف عـن

الظـروف في مسـتويات الشـعور بالوحـدة والـدعم الاجتمـاعي المـدرج لـدى مجموعـات الاسـتقواء (غير مشاركين- مستقوين - ضحايا - مستقويين

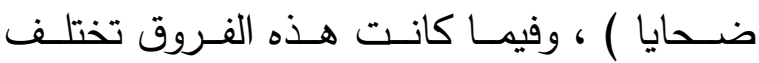
باختلاف مجموعات الاستقواء ، او جنس الطالب او التفاعل بينهما - الت

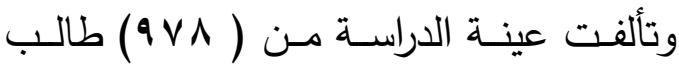
وطالبـة ، ( r الصف العاشر، وتم تصنيفهم الى ( N (Av) غير

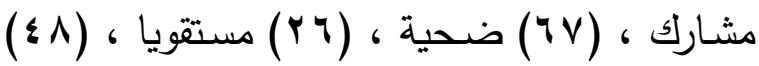
مستقويا ضحية . وطبـق علـى افـراد عينــة الدراســة مقيـاس الاسـتقواء والوقـوع ضــحية وشـر الوحـدة والــدعم

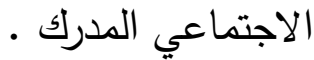

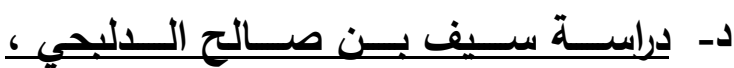

بعنــوان : المشــكلات الارســية لطــلاب

\section{الرحلة الابتدائية ، ب ...r :}

هدفت الدراسـة إلى التعرف علي مشكلات التلاميذ المدرسية لدي طلاب المرحلة الابتدائية في مدينـة الريـاض مـن وجهـة نظـر المعلمـين كوالتعـرف على الاسـاليب بـين المعلمسين في التعامل ع مشكلات التلاميذ المدرسية ، والتعرف علـي نظـرة المعلمـين الـى مشـكلات التلاميـذ واختلافها باختلاف متغيرات الدراسة ، الى جانب التعرف على المقترحات التي يقدمها المعدون والتي تسـاعد في الوقايـة من مشكلات التلاميذ في المرحلة الابتدائية بمدينة الرياض • وتكونــت عينـة الدراسـة مسن ( 0\% ) مسن مجتمـع الدراسـة الأصـلي ، وقـد بلغـت ( س (T) معلمـاً يعملـون فـي مـدارس الابتدائيـة بمدينـة

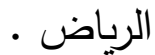

وقـد اسـتخدم الباحثث في دراسـته المـنهج الوصـفي ، وطبقــت اداة الدراســة المتمثلـة فـي الاستبانة على عينة الدراسة . وقد انتهت الدراسـة إلى عدة نتائج مـا يهم الدراسة الحالية منها ، هو ما أشارت اليه الدراسة الى انهه من ابرز مشكلات الطـلاب التي ذكرها المعلمون فبها يختص بالطلاب أنفسهم وهى كثرة عبارات الشتم فيمـا بينهم بمـا يشير على ظـاهرة التتمر اللفظي ، وكان ابرز اساليب المعلمين في التعامـل مـع مشكلات التلاميذ الاحالـة للمرشـــ وتقـديم النصــح للطالب ، ومناقشــة الطالـب ، 


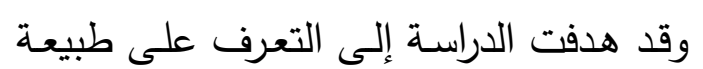

الآثار النفسية لأحداث العنف لدي طلبة الجامعة ،

$$
\text { ولأجل ذلك وضعت الباحثة فرضيتين : }
$$

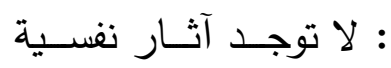

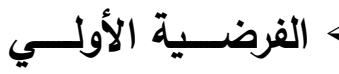

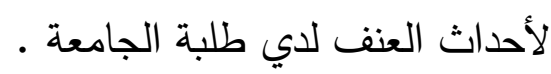

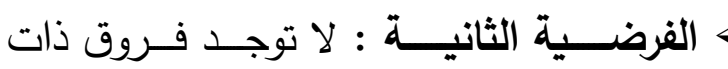

دلالــة احصـائية فى الآثار النفسية لأحـداث

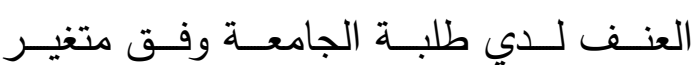

الجنس.

ولغـرض اختبـار فرضـيات الدراسـة ، قامـت

الباحثة ببنـاء أداة للقيـاس متثثلة بمقيـاس الآثار

النفسية لأحداث العنف وفق النظرية السلوكية .

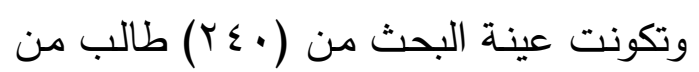

طلبة الصف الثامن من مرحلة التعليم الاساسي

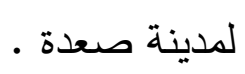

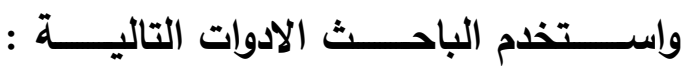

مقيساس تقــير الـــات ، مقيساس السـلوك

$$
\text { العدواني - مقياسن }
$$

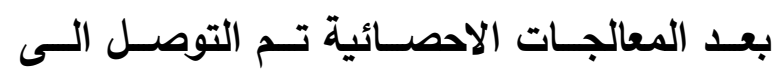

$$
\text { النتائج التالية :- بعدالت الاحت }
$$

ا. توجد علاقـة ارتباطيـة دالـة احصـائيا على لـى

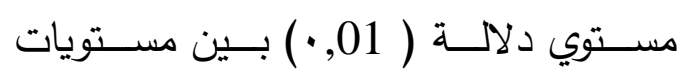

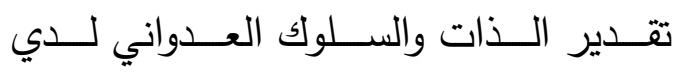

طلبة المرحلة الاساسية .

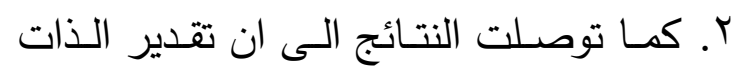

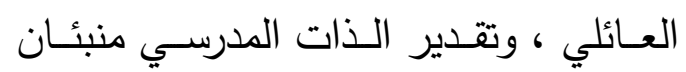

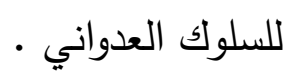

وقد كثفت نتائج الدراسة :

ا. مسـتوي الثـعور بالوحـدة لـدي مجموعـة

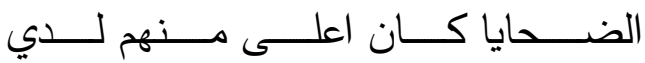

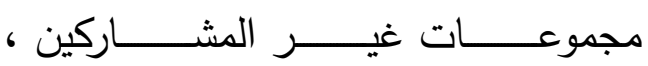

والمستقويين ، والمستقويين الضحايا .

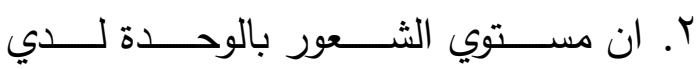

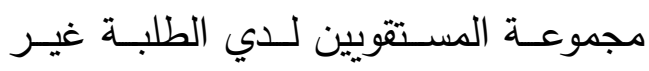

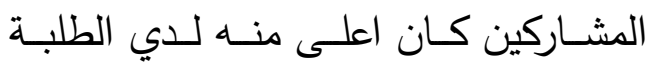

$$
\text { · المستقويين }
$$

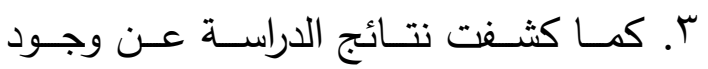

فـروق دالــه احصــائيا بـين مجموعـات التهات

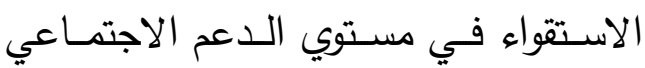

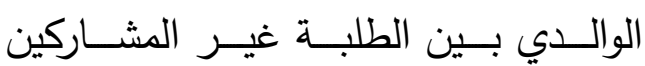

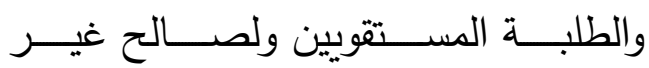

$$
\text { • المشاركين }
$$

؛. وجـود فـروق دالـة إحصـائية في مسـتوي

دعــم الــزملاء بـين غيــر المشـــاركين

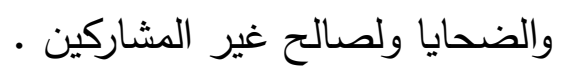

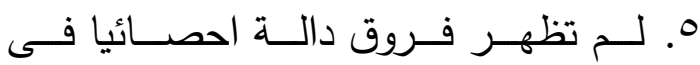

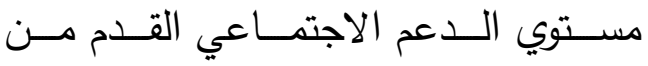

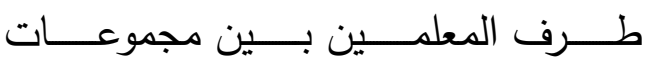

$$
\text { الاستقواء ماء }
$$

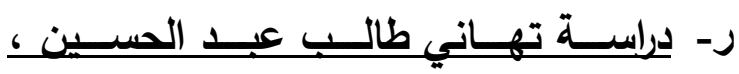

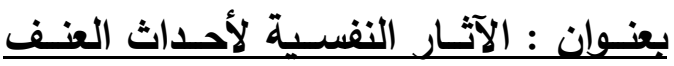

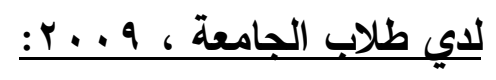

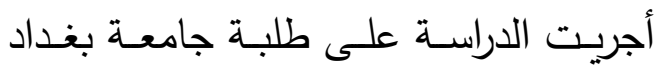

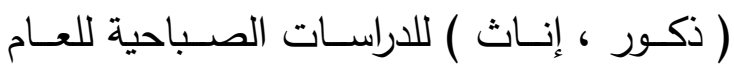

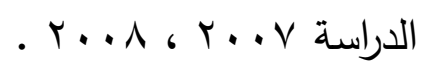




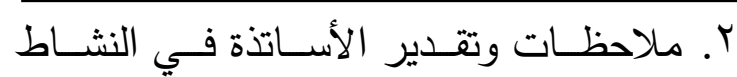

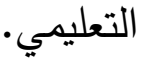

r. البحث في ملف التلميذ عن سوابق تتعلق بتناول المخدرات وسلوكيات اخري مرفوضة

$$
\text { قام بها في المؤسسة . }
$$

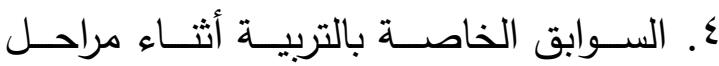
الطفولة .

๑. نتائج التحليل الخاصة بالهرمونات .

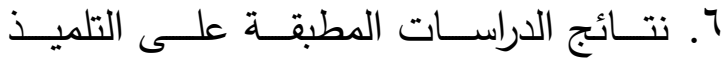
والمتعلقة بالجانب الفيسيولوجي النفسي .

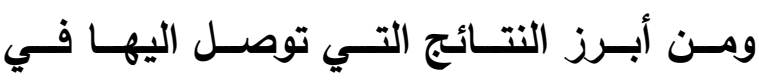
الاراسات المعمقة هي كالتالي :

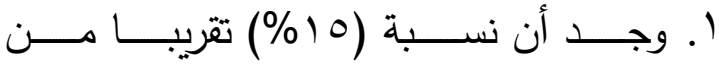

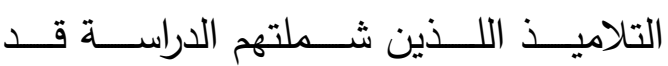
تعرضـوا لهـذا النـوع مـن السـوك باسـتمرار

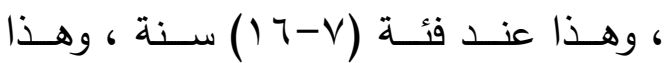

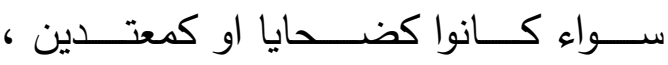

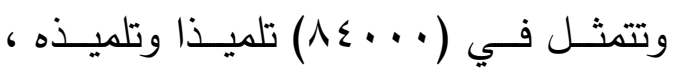

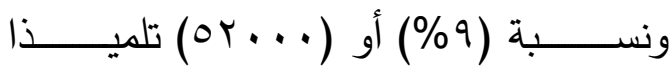

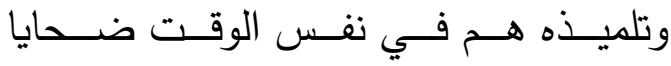

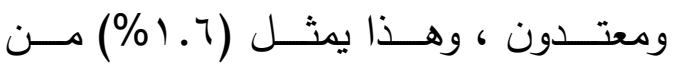

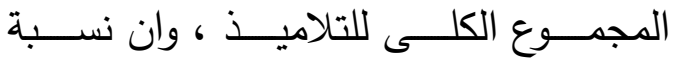

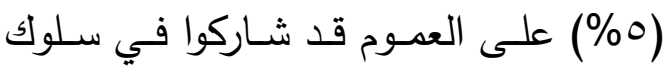
اكثــر خطــورة ســـواء كـــانوا معتــدين او

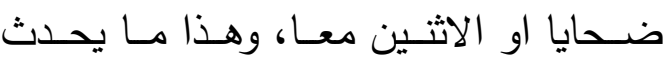
مره في الاسبوع او غالبا . المان

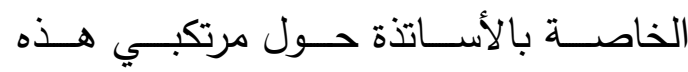

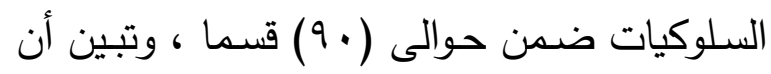
ما هؤلاء التلاميذ بخصوص هذا السلوك هو فعلى

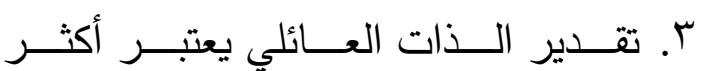

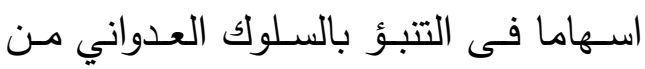
تقدير الذات المدرسي •

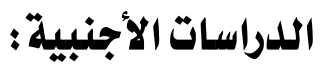

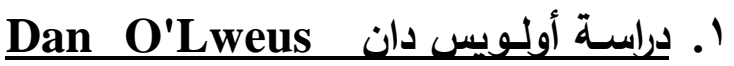

\section{$: 1983$}

هدفت الدراسة خاصـة الى ايجاد إيجابيات عن ادراك التلاميذ بهذا السلوك وردود افعـالهم واتجاهـاتهم ، وكـذا الثـأن مـن طـرف الأسـاتذة والأوليـاء ، هذا بالإضـافة الـى تحديد الأسباب وراء هذه السلوكيات . شملت الدراسة (Ylo) مدرسة في النرويج

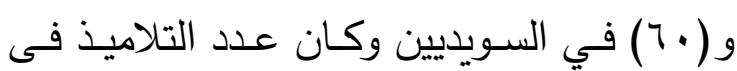

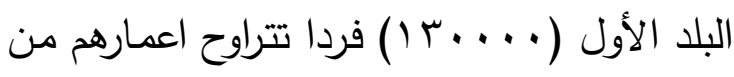

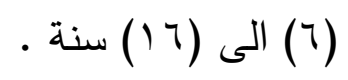

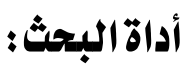

استعمل الباحث أداة الاستبيان التي ضمنها

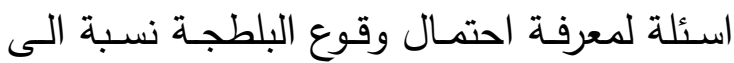

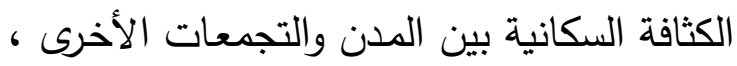

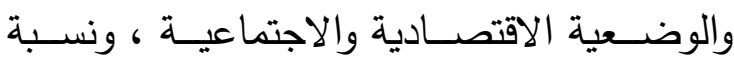

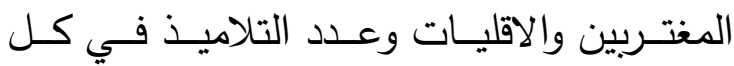
مؤسســة تعليميــة وفـى كـل قسـم ، والتركيبــة الخاصة بهيئة التدريس من حيث السن ، الجنس

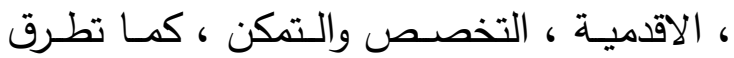
الى جوانب هامة من خلال مقابلات مع التلاميذ والاولياء ( الأمهات ) تناول فيهما ما يلي :

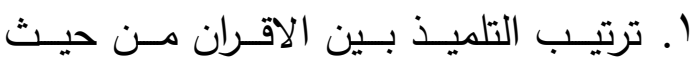

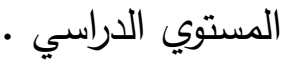


ومن الخطأ بحث الظـاهرة من حيث كونها

فقط مشكلة للضحية الواقع عليها الضرر فحسب ،فلمشـكلة صـورتان مؤثرتـان تـأثيرا شـديدا على لى المجتعات ، فالصورة الأولى وهى الأولى بالطبع من اهتمام وايجاد سبل الحل وهى صورة الضحية التـي يقـع عليهـا الفعـل الاكراهـي المـؤلم ، لكـن الصورة الأخرى وهى صورة الطفل ومجموعة من

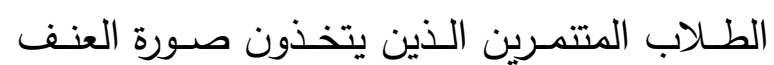
سـلوكا ثابتـا في تعـاملاتهم ، انها صـورة ضـحية أخري مـن نـوع مغـاير ووجـوده اشــ خطـرا على

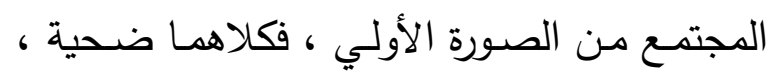

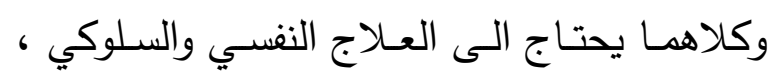

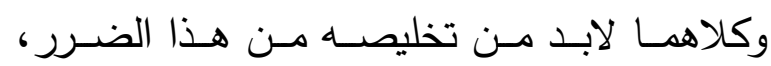
وخاصـة انهمـا معـا يشكلان عنصـري بنـاء الامـهـ المسـتقبلية ، فالمعتـدي والمعتدي عليـه عضــوان اساسيان في كل المجتمعات ، واذا اهملنا الطفل المعتـدي ولـم نقومـهـ تربويـا وسـلوكيا سـيتعرض حلف اطفال اخرين للوقوع في نفس المشكلة ، وسيساهم

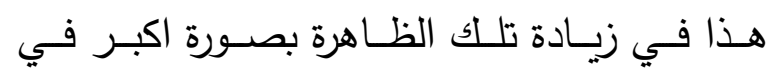
المجتمع ذللك مع ضرورة صب كل اهتمامهم على لهى لهـ الطفل الضحية الذي وقع تحت اهمال الكثيرين •

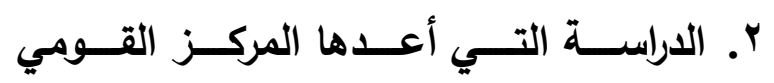
لصحة الأطفال والتنمية البشرية : لاعله

National institute of child health and human development

فقــ اتضـح ان اكثر مـن مليـون تلميـذ مـن

تلاميـذ المـدارس في الولايـات المتحـدة الامريكيـة تورطوا في التنمرسواء كانوا ضحايا او متنمرين ، كمـا ان اكثر من منـة وستون الف تلميذ يهربون
ولـيس مبــالغ فيـهـ ، لان عـدد التلاميـذ الـذين يقومون بهذا السلوك - معتدون او ضحايا - هم أكثر من هذا ولأن الارقام تتعلق بثلاثة اشهر من الدراسة لأقل سنا الاضعف بدنا هم اكثر تعرضا لهذا السلوك العنيف الجسدي ، حيث يقل هذا ما يتقدم الاطفال في السن ، الذكور لهذا النوع من

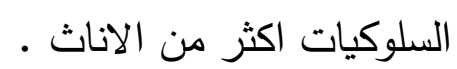
اكثر خلال السنوات الأولى للمرحلة الثانوية وهـذا مـا يوافق مرحلـة المراهقـة ،وهـذا السـلوك الفتيـات تقوم بـه بطرق غيـر مباشـرة كالنبـ او الامتناع عن التواصل او الحديث معهن ، الا ان

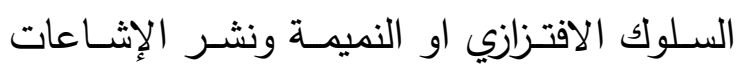
والتلاعب بالعلاقات العاطفية ، والذكور يقومون بالاسـتفزازات سـواء بالإيمـاءات او الكلمـات او

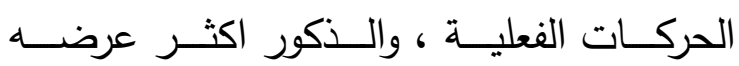
وممارسـة لهذا النوع مـن السلوكيات سـواء كانوا معتدين او ضحايا أخيرا توصل الباحث سواء مع التلاميذ في النـرويج او مـع التلاميذ في السويد ، وسـواء مـا تعلـق بأسـاتذة او الاوليـاء بـان هـذه السـلوكيات

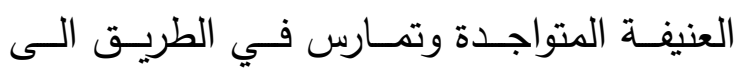
المدرســة او بهـا ، وانتشــار هـــه الظـاهرة فـي المؤسسـات التعليميـة سـواء بالمـدن الكبـرى او

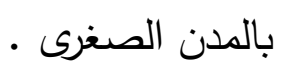
يتعرض للحرمـان او الطرد مـن المدرسـة ، وكذلك يظهر قصسورا مـن الاستفادة من البرامج التعليمية المقدمة له ، كما انه قد ينخرط مستقبلا في أعمال إجرامية خطيرة (Steohens,2006) 


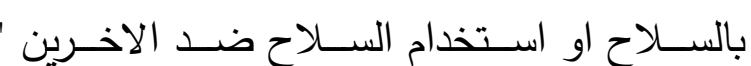

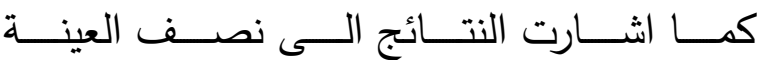
تعرضــت الـى تنمـر علـى الممتلكـات والاشـياء التـي تخصــهم ، وكانـــ مجموعــة المتتمـرين هـي الاكثـر تتمـرا ، امـا الضــحايا فكـانوا مـن

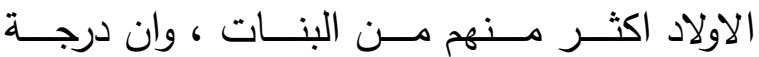
تتمــر الاولاد اكثــر قلــيلا مــن البنــات ، وان البنـات فقــــــــن الــى التتمـر غيـر المباشــر اكثـر مـن الاولاد ، كمـــا اكـدت الدراســة بانــهـ لـيس هنـاك اخـتلاف فـي المسـتويات الدراسـية

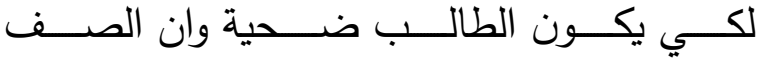
السـادس اكثـر الصـفوف مشــاركة فـي عمليـة

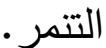

Solberg \& Olweus ， ) دراسة قام بها

2003 ) تقدير منع انتشـار التنمر بين تلاميذ التان المدارس ولاية بيرغن في النرويج ، وعلاقة التتمر بـبعض المتغيـرات ، تكونــت عينــة الدراسـة مـن فئن تلاميذ في الصف الخامس وحتى الصف التاسع

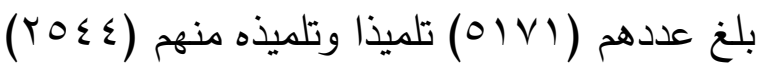

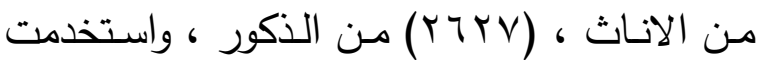
الدراسة مقياس التنمر والذي تكون من (דب) سؤال بالإضـافة الى ترشيحات الاقران واشـارت النتائج الى ان التلاميذ والضحايا اظهروا مستويات عالية

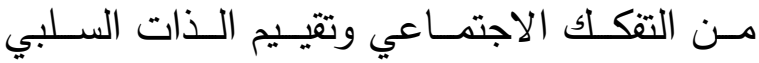
وانخفاض دافعية الانجاز ن وميول اكتئابيه اكثر من غيرهم من الضحايا ، امـا التلاميذ المتنمرون فقد اظهروا عدائية اكثر وسلوكيات غير اجتماعية اكثر ، وانخفاض دافعية الانجاز ، بالمقارنـة مـع المجموعـات غير المشـاركة في التتــر ، ولـدي
من المدارس يوميا خوفا من تتمرالآخرين ، كما

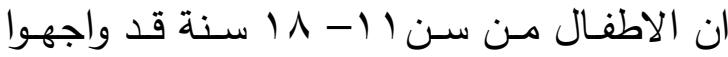
شـكلا مـن اشـكال التنــر في اثنــاء وجـودهم لتهم بالمدرسة .

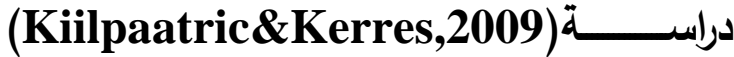
والتـي هـــت الـى دراسـة تصــورات التلاميـــ

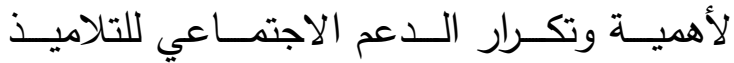
الـذين صـنفوا على انهم متتمـرون او ضـحايا متتمــرون ، وتكونـــت عينـــة الدراســـة مــن

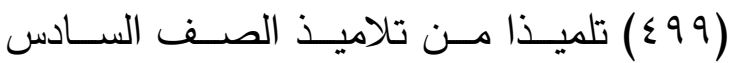
وحتى الثامن في مدرسـة متوسطة في الريف

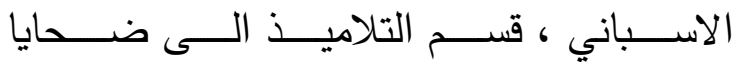
ومتتمـــرين وضـــــايا / متتـــــرين وغيــر منغمسـين في التنــر ، طبـق علـيهم مقيساس

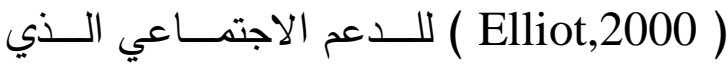

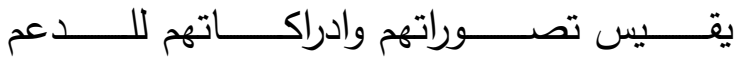

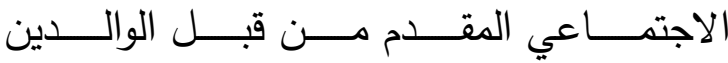
والمعلمـين والــزملاء والاصــدقاء ، واشـــارت النتـائج الـى ان (Y / \%) مـنهم كـانوا متتمـرين

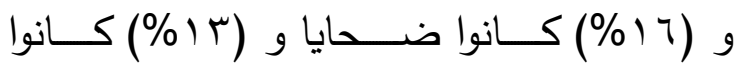

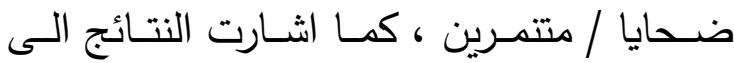
وجــود فــروق ذات دلالــــة احصـــائية بــين المجتمعــات المختلفـــة فـي كـلا مـن تكــرار

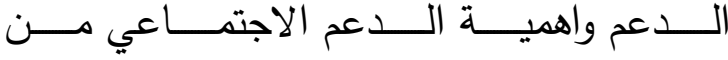

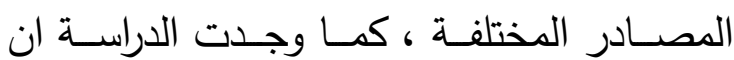
التنــــر الثــفوي اللفظــــي المباشـــر والغيــر

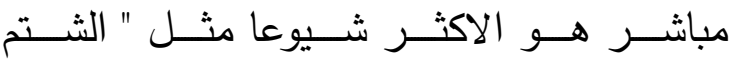
والســخرية والكــلام البـذيه والغـيظ " والتنــــر

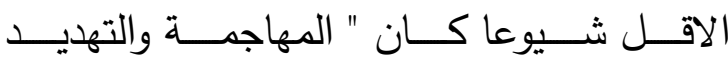


سيرتهم الاجتماعيـة ـ اذ ينزع الافراد في البدايـة

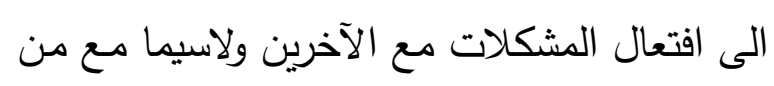
هم افضل منهم محاولة اخافتهم •ويشير هولي الى الى

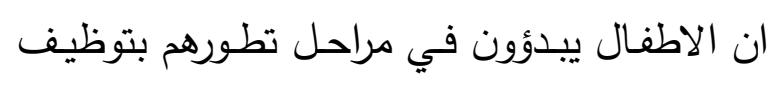
وسائل اكثر قبولا اجتماعيا للسيطرة على الآخرين

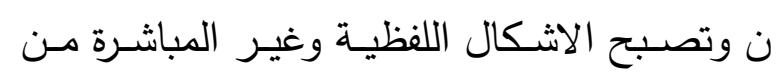
التتمر أكثر شيوعا من الأشكال الجسدية ، ومـع مـرور الوقت يصـبح السـلوك الذي يعرف عـادة

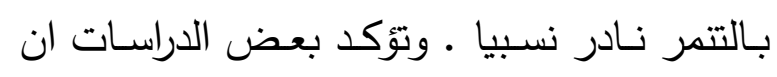
التنمر الجسـي اكثر شيوعا في مراحل الطفولـة المبكرة منها في المراحل المتأخرة ، وان ما يعرف بالتتمر ، يصسبح أقل وضـوحا تدريجيا مـع تقدم

(Rigby .2003). الاطفال في السن r- التنمر في ضوء النظرية السلوكية: تري النظرية السلوكية ان التنمر قابل للتكرار

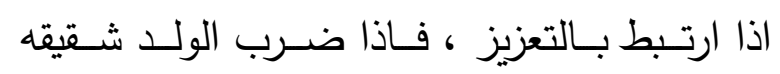
وحصل على ما يريد فانه سوف يكرره مره اخري

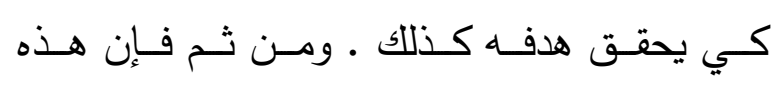
الاسـتجابات التي تبقى لتصبح جزء مـن سـلوك الفرد هي الاستجابات التي دعمت أي التي اعقبها اثر طيب وصسار للاستجابات التي يعقبها تدعيم

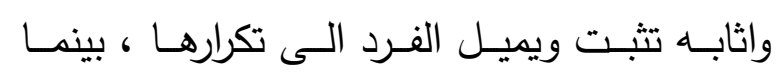

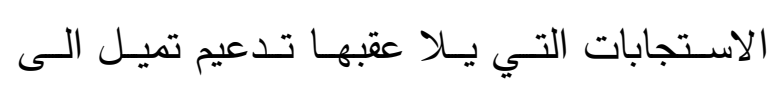

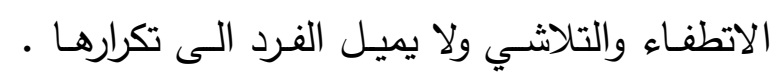
أي ان السـلوك يقوي او يضـف بنـاء على اثلى وهر ونتيجته فيمـا يتعلق بالفرد ، ويعرف هذا بقانون الاثر في نظرية التعلم الإجرائي عند اسكنر ومفاده ان السلوك الذي يلقي تعزيزا ويؤدي الى الشـعور

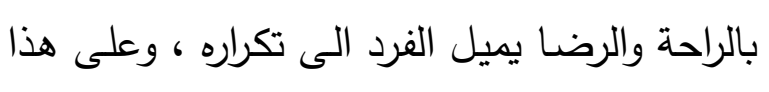

مقارنـة الذكور والانـاث اظهرت النتائج تعرض الاناث الى التتمر اكثر من الذكور . سابعاً : الإطار النظري للدراسة:

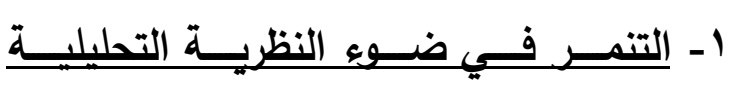
( خبرات الطفولة ): يؤكد التحليليون القدامة ان تشئية الطفل في أثناء الرضـاعة يكون قد اختبر خبرات سـارة او

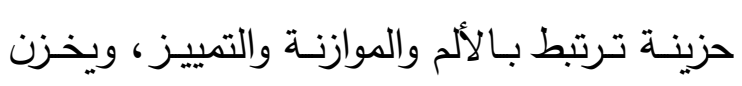
مثـل هـذه الخبـرات في ذاكرتـهـ ، وتبقـى تلـح وتسـعي الـى الظهـور في أي مناسـبة، وأحيانـا تفثـل المقاومـات الشخصـية فـي إخفــاء هـــهـ

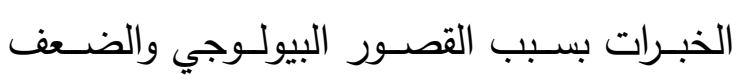
الجسـي، ووعدا بقدوم الأيـام المناسبة لإظهار هذه الانفجارات الانفعالية على صورة هجوم، او اعتداء او تتمر • اما عن وجهة نظر المحللين النفسيين الجدد لتنمر فيري أدلار ان هناك قوى أنى دافعـه مستقله لهذا السـوك توجد في اللاشعور وتوجه السلوك، ويحدث ذللك اذا ما تواجد فردان او اكثر في موقف عدائي او استفزازي • وتري ميلاني كلاني ان التنمر يعدر داخل الطفل منذ بداية الحياه ويكون هذا الدافع عنيفا جدا ، حتى ان الطفل يمـر بخبـرات مـن القلق الشـديد تدور

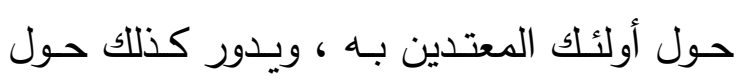

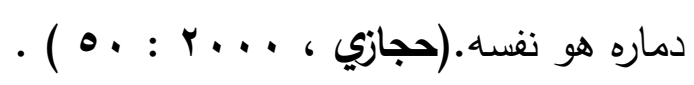

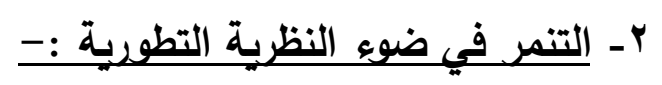
تعتمـد بـبعض تفسيرات التنمـر على فكر تطور الطفل ، فهي تشيرالى ان التنمر يبدأ في

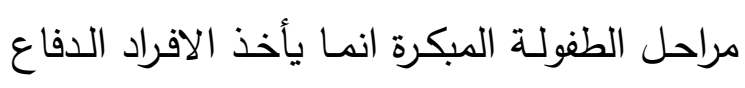
عن انفسهم على حساب الاخرين من اجل فرض 
إذ انهـم لا يعـالجون المعلومــات الاجتماعيـة ، بأسلوب سليم وهم غير قادرين على إطلاق أحكام واقعيـة على نوايـا الاخرين ، وليس لديهم المعرة الكافية حول تصور الآخرين لهم ـ وبناء على ذلك تقدم نظريـة معالجة المعلومات الاجتماعية تفسيرا للعجـر فــي المهــارات الاجتماعيـة للأطفـــال

\section{(Larke \& beran:2006.sutton \& smith : 1999)}

\section{هـ التنمر في ضوء النظرية المعرفية :-}

يختلف المتتمرين عن الضحايا في الجوانب والعمليات المعرفية فالمتنمرين يدركون انفهه بأن لايهم القدرة على التحكم في البيئة التي يعيشون فيهـا ، فهم يدركون سلوكهم مـن خـلال التمركز حول الذات وغالبا ما يبررون سلوك المتتمر الذي يقومون به ضد الضحية من وجهة نظرهم حيث يزعمون ان الضحايا يستحون هذا التتمر والعقاب كما يكن لدي هؤلاء المتنمرين - كما يشير دودج

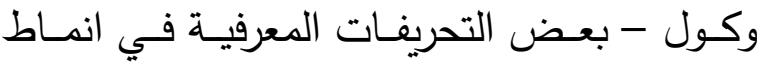
تفكيرهم مما يجعلهم يميلون الى الاعتقاد اعتقاد خاطئ بان لاي الآخرين مقاصد ونوايـا عدوانيـة تجـاهمه وهنـاك جانب أخـر مـن أنمـاط التفكير الخطأ لدي المتنمرين ويتمثل ذلك في ان أسلوب تفكيرهم يتسم بعدم النضـج المعرفي ن فهم دائمـا يميلون الى التفكير أحادي الاتجاه نحو الآخرين، ولديهر مفهوم إيجابي عن الذات ومستويات مرتفعة من الثتـة بالنفس ولديهم اتجاهـات ايجابيـة نحو

العنف. ( Dodge \& Coie1987)
الاسـاس فان سلوك التنمر يحدث نتيجة لعملية التعزيز التي يتلقاها المتتمر من أقرانه على مثل هذا السلوك ، وقد يحصل المتنمرايضـا على هذا

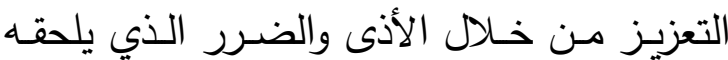
بالضـحية ، بمعنـي انـه عنــما يعتدي المتنمـر على الضحية ويميل الضحية الى البكاء ولاسيما في المدرسـة الابتدائيـة فغن ذلك يعزز سـوك

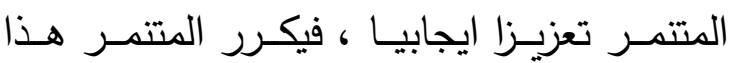
السلوم مرة ثانية ولكن اذا رد الضحية وانتقم من المتتمر - وهذا نادرا ما يحدث- فان ذلك يعزز

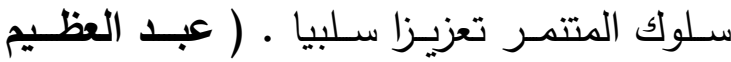
( r...

لذللك وفى ضوء النظريـة السلوكية نجد ان المتنـــر عـزز ســـكه الافـراد المحيطـين بــهـ كالزملاء والأصدقاء وإحرازه درجة النجومية بين

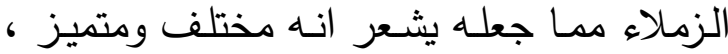

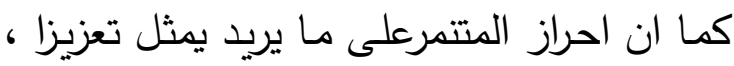
وهذا يدفعه الى انشاء مواقف تتمريه وبنائها في الاعتداء على الاقراد المحيطين به من زملائه .

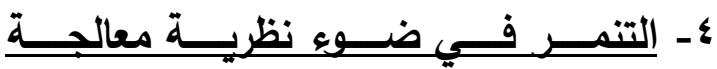

\section{المعلومات الاجتماعية:}

بما ان سلوك التتمر يقع في سياق مجموعة

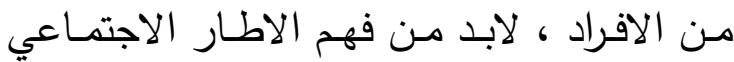

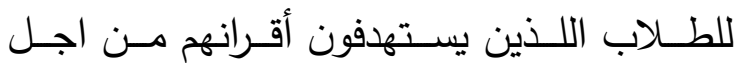
الادرالك الثـامل لمفهوم التنمر · Larke \&) beran:2006)

يختلف الباحثون حول المهارات الاجتماعية

للأطفال اللذين يمارسون سلوك التتمر حيث ان المتتمرين يعانون نقصا في المهارات الاجتماعية 
المدارس الثانويـة الموجودة بمدينـة المنصورة التي

$$
\text { تتمثل في :- }
$$

( ) مدرسة الثانوية بنات الجديدة

Y) مدرسة جيهان السادات الثانوية بنات

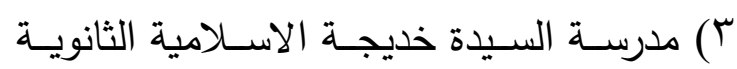

للبنات

ع) مدرسة ام المؤمنين الثانوية للبنات

0) مدرسة الملك الكامل الثانوية للبنين

7) مدرسة الثانوية العسكرية للبنين

V) مدرسة ابو النجا الثانوية للبنين

^) مدرسة طه حسين الثانوية للبنين •

$$
\text { r. المجال الزمني: مله }
$$

اسـتغرقت الدراســة الميدانيــة أربعــة اشــهر

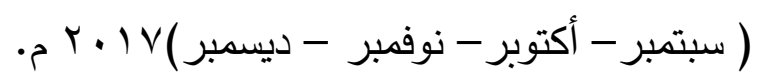

أسلوب المعالجة الاحصائية :

لجأت الباحثة الى الأسلوب الإحصسائي في

التحليـل مـن أجـل الحصـول على نتـائج صـادقه

$$
\text { وواضحة. }
$$

محاور الاراسة الميدانية :

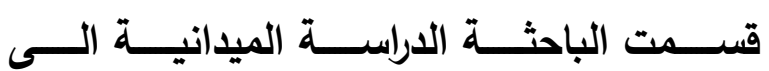

$$
\text { المحاور التالية : - الباحنة }
$$

• الخصائص العامة لعينة البحث

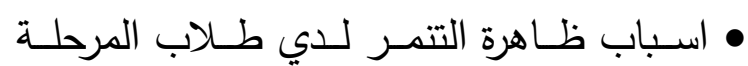

$$
\text { الثانوية }
$$

• مدي انتشار ظاهرة التتمر لدي طلاب المرحلة

$$
\text { الثانوية }
$$

• اشكال التتمـر الـذي يمارسـه طـلاب المرحلـة

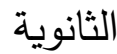

\section{ثامناً: الإجراءات المنهجية للدراسة :}

المنهج المستخدم في الاراسة :--

تعتمـد الباحثـة في دراسـتها علىى المـنهج

الوصـفي التحليـي الـذي يعبـر عـن الظـاهرة

الاجتماعية كما توجد في الواقع بصورة كيفية من

خلال رصد التغير الذي طرأ على ظاهرة التتمر

والمنهج التحليلي بمحاولة ربط الاسباب بالنتائج

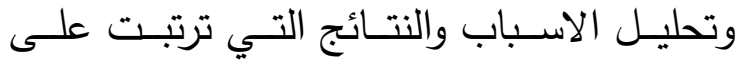
الابعـاد الاجتماعيـة والاقتصـادية لظـاهرة التنمر ولري لدي طلاب المرحلة الثانوية والمنهج الاحصـائي الذي يعد منهجا أساسيا للدراسـات السوسيولوجية من خلال ترجمات الدراسـة الميدانية في جداول

احصائية لتحليلها .

مجالات اللدراسة : - مجات

ا ـ مجتمع البحث (المجال الجغرافي)

طبقـت الدراسـة الميدانيـة على عـد مـن

المدارس الثانوية بمدينـة المنصورة وتتقسم مدينة المنصــورة الـى حـي غـرب وحسي شـرق وعلى أطرافهـا توجـد أحيـاء جديلـة وقولونجيـل ومنيـة سندوب وعزبـة الشال ، ويبلنغ عدد سكان المدينة حوالى (q § ₹) الف نسمة . r ا بـ المجال البشري

يتمثل مجتمـع البحث في عدد من طلاب المرحلة الثانوية (ذكور - اناث ) .

عينة الدراسة:

طبقت الدراسـة الميدانيـة على عينـة قوامها

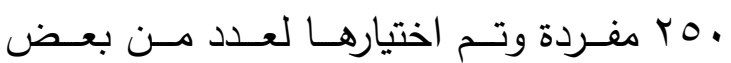
• دورالتكنولوجيا في انتشار التتمر الدراسي 
تشير بيانات الجدول السـابق الى توزيع أفراد

العينـة حسب السـن ففي الترتيب الأول من 7 أ-

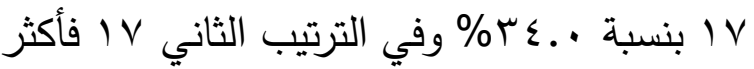
بنسبة . . ب \% وفي الترتيب الثالث أقل من 10

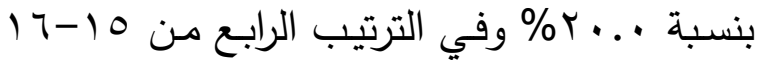

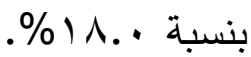

نستتتج مما سبق اختلاف الفئة العمريـة التي

تنتمـي اليهـا الغالبيـة العظمى مـن عينـة الدراســة

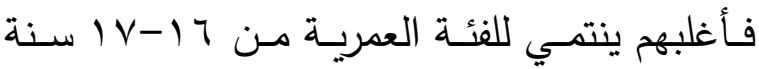
وهـذه المرحلـة هـي مرحلـة المراهقـة وهـي العمـر

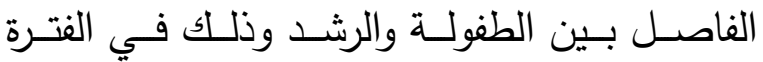
العمريـة المُمتدة من سن 10 إلى في بدايتها ونهايتها من شخص لآخر ومن مجتمع لآخر وعلى حسب الجنس فالأنثى تبلغ قبل الذكر

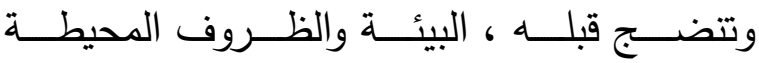
بالشخص. فقد تبدأ مرحلة المراهقة من سنس ا وقد تنتهي في سن 9 1 ، ولربمـا تبدأ اساسـا من سن 10 وتنتهي في سن 0ب تقريبا ، كحد أقصى.

جدول رقم (r)

\begin{tabular}{|c|c|c|}
\hline المئوية \% & التكرار & المتغيرات \\
\hline$r \leq .$. & 7. & الصف الاول الثانوي \\
\hline r... & 9. & الصف الثاني الثانوي \\
\hline$\varepsilon \cdot$. & $1 \ldots$ & الصف الثالث الثانوي \\
\hline$\% 1 \ldots$ & ro. & المجموع \\
\hline
\end{tabular}

تشير بيانات الجدول السـابق الى توزيع أفراد العينة حسب الصف الدراسـي ففي الترتيب الأول

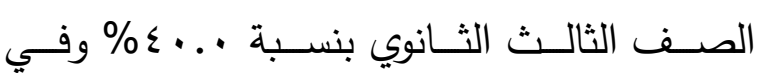

الابعاد الاجتماعية الاقتصادية لظاهرة التتمر

لاي طلاب المرحلة الثانوية

• دور الدولـة والجهات المعنيـة في الحـد مـن انتشـار ظـاهرة التتمـر لـدي طـلاب المرحلـة

الثانوية.

\section{تاسعاً: عرض وتحليل الدراسة الميدانية :}

جدول رقم (1)

توزبع أفراد العينة حسب النوع

\begin{tabular}{|c|c|c|}
\hline النسبة المئوية ٪ & التكرار & المتغيرات \\
\hline 09.1 & $1 \leqslant \wedge$ & ذكر \\
\hline$\varepsilon . .1$ & $1 . r$ & انثي \\
\hline$\% 1 \ldots$ & ro. & المجموع \\
\hline
\end{tabular}

تشـير بيانـات الجـدول السـابق الـى توزيـع أفراد العينة حسب النوع ففي الترتيب الأول ذكر بنسبة ^ـ ـ ^^\% وفي الترتيب الثاني انتى بنسبة . \%०4.ร

نستتتج مما سبق غلبة الذكور على الاناث في ارتكاب وممارسـة التنمر المدرسي وذلك يدل أن التتمرلا يقتصر على الذكور فقط ولكن وصل ايضـاً الى الإنـاث على الرغم من كل الصفات الأنثوية التي تتسم بها الإناث.

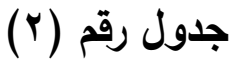
توزيع أفراد العينة حسب السن

\begin{tabular}{|c|c|c|}
\hline النسبة المئوية \% & التكرار & المتغيرات \\
\hline$r \cdot . \cdot$ & o. & اقل من ه \\
\hline $1 \wedge .$. & $\leq 0$ & $17-10$ \\
\hline$r \varepsilon$. & 10 & $1 v-17$ \\
\hline ү^.. & v. & V افأكثر V V \\
\hline$\% 1 \ldots$ & ro. & المجموع \\
\hline
\end{tabular}


جدول رقم (0)

توزيع أفراد العينة حسب أسباب انتشار التنمر

\begin{tabular}{|c|c|c|}
\hline \multicolumn{3}{|c|}{ داخل المدارس } \\
\hline النسبة المئوية & التكرار & المتغيرات \\
\hline $1 \wedge .$. & $\leqslant 0$ & أسباب شخصية \\
\hline$r \leq . \cdot$ & 7. & أسباب اسرية \\
\hline$r \cdot . \cdot$ & 0 . & أسباب اجتماعية \\
\hline 17. & $\varepsilon$. & أسباب اقتصادية \\
\hline r.t. & 00 & أسباب مدرسية \\
\hline$\% 1 \ldots$ & ro. & المجموع \\
\hline
\end{tabular}

تشير بيانات الجدول السـابق الى توزيع أفراد

العينة حسب أسباب انتشار التتمر داخل المدارس ففي الترتيب الأول أسباب أسرية بنسبة . .ـ ب \% وفـي الترتيـب الثـاني أسـباب اجتماعيـة بنسـبة

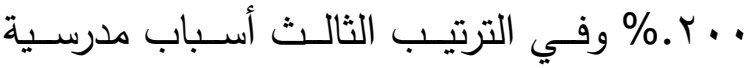

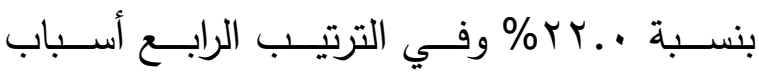

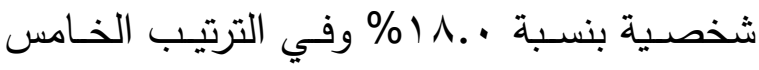
أسباب اقتصادية بنسبة . .7 (1\%.

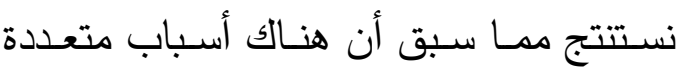
ومتشـابكة تسـهم في إيجـاد سـلوكيات عنيفـة بين طلبـة المـدارس، يمكـن تقسـيمها إلـى الأســباب

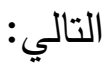

أسباب اجتماعية -اقتصادية -عقلية - ذاتية تتعلـق بالطالب نفسـه - أسـباب تتعلـق بالعمليـة التعليميـة ذاتها -أسباب تتعلق بـالحي والسكن أسباب تتعلق بجماعة الرفاق.

الترتيـب الثـاني الصـف الثـاني الثـانوي بنسـبة

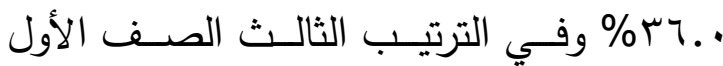
الثانوي بنسبة . . ع ب\% من السابق يتضح اختلاف الصف الدراسي لعينة البحث ففي المقدمة الصف الثالث الثانوي ثم الصـف الثاني الثانوي وأخيـراً الصـف الأول الثـانوي ممـا يثـــت أن هـذه الفئة هـي الأكثر ممارسـة للتنمر المدرسي أكثر من غيرها وكذلك

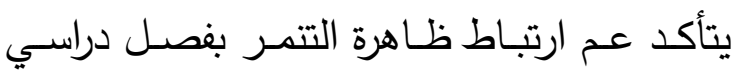
معـين فالصـف الأول والثـاني يوجـــ متتمـرون بing

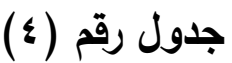

توزيع أفراد العينة حسب مستوي دخل الأسرة

\begin{tabular}{|c|c|c|}
\hline ا النسبة المئوية & التكرار & المتغيرات \\
\hline r^.. & $v$. & اقل من ... r \\
\hline $1 \wedge .$. & $\leq 0$ & $r \ldots-r \ldots$ \\
\hline r... & 00 & $\varepsilon \ldots-r \ldots$ \\
\hline rr.e & $\wedge$. & . . . . عفأكثر \\
\hline$\% 1 \ldots$ & ro. & المجموع \\
\hline
\end{tabular}

تشـير بيانـات الجدول السـابق الى توزيـع

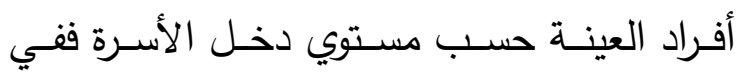

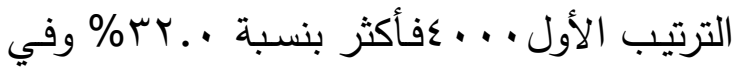

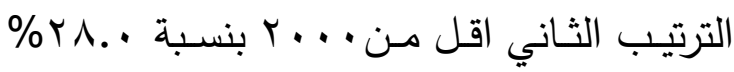

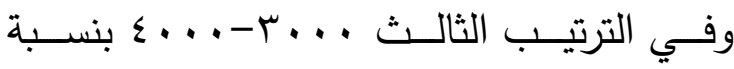

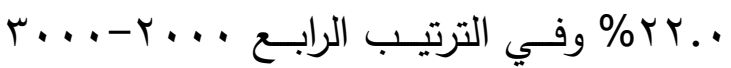

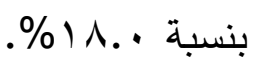

نستتتج مما سبق اختلاف مستوى دخل الأسرة

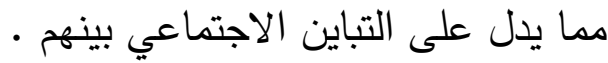


للتنمر الصف الثالث الثانوي بنسبة . . بـ \% وفي الترتيـب الثـاني الصــف الثـاني الثـانوي بنسـبة

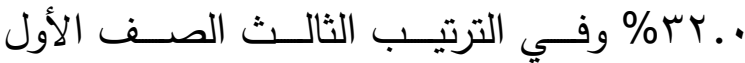

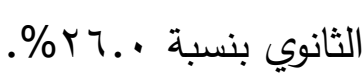

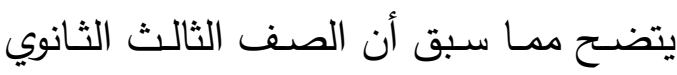
الأكثر ارتكابا للتنمر المدرسي وهذا لا يعني خلو الصفوف الأخرى من هذه الظاهرة بينما يوجد من يرتكبها في الصف الأول والثاني.

\section{جدول رقم (^)}

توزيع أفراد العينة حسب مدى انتشار ظاهرة

\begin{tabular}{|c|c|c|}
\hline النسبة المئوية \% & التكرار & المتغيرات \\
\hline VY.. & 11. & انتشار سريع \\
\hline Y^.. & $v$. & انتشار بطيء \\
\hline$\% 1 \ldots$ & ro. & المجموع \\
\hline
\end{tabular}

تشير بيانات الجدول السـابق الى توزيع أفراد العينـة حسب مدى انتشـار ظـاهرة التتمر الدراسـي

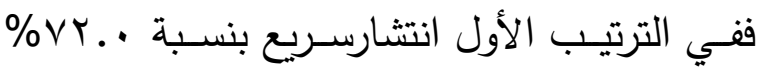

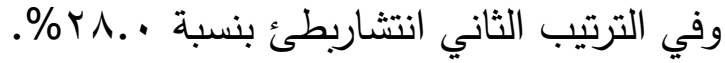
نستتتج مما سبق أن ظلاهرة التتمر المدرسي منتشـرة انتشـار سـريع في المجتمع وهذا مـا أكدته الغالبية العظمى من عينة الدراسة. جدول رقم (9) توزيع أفراد العينة حسب نوع التنمر المدرسي الأي تمارسه

\begin{tabular}{|c|c|c|}
\hline النسبة المئوية ٪ & التكرار & المتغيرات \\
\hline$\varepsilon \wedge . \cdot$ & $k$. & تتمر جسدي \\
\hline А.. & $r$. & تتمر جنسي \\
\hline$\varepsilon \varepsilon$. & 11. & تتمر لفظي \\
\hline$\% 1 \ldots$ & ro. & المجموع \\
\hline
\end{tabular}

جدول رقم (†)

توزبع أفراد العينة حسب الطلاب الاكثر ممارسة

\begin{tabular}{|c|c|c|}
\hline النسبة المئوية \% & التكرار & المتغيرات \\
\hline$\varepsilon \cdot$. & $1 \ldots$ & المتفوقين \\
\hline $7 .$. & 10. & المتأخرين دراسيا \\
\hline$\% 1 \ldots$ & ro. & المجموع \\
\hline
\end{tabular}

تشـير بيانـات الجـدول السـابق الـى توزيـع

أفراد العينة حسب الطلاب الاكثر ممارسة للتتمر الدراسـي ففي الترتيـب الأول المتـأخرين دراسـياً بنسبة . . . 7\% وفي الترتيب الثاني المتفوقين

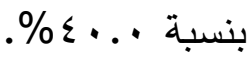
من السـابق نسـتتج أن الطـلاب المتأخرين دراسـياً هــم الطـلاب الأكثـر ممارسـة للتنــر المدرســي عـن الطــلاب المتفــوقين فالطالـبـ المتفوق لا يهتم بغير دراسته وتحصيله الدراسي أمـا الطالـب المتـأخر فـي التحصـيل الدراسـي يحساول أن يثـخل نفسـه ويظهر شخصـيته بـين أقرانه بكافة أشكال الشغب والتتمر .

جدول رقم (v)

توزيع أفراد العينة حسب المستويات الاكثر ممارسة للتنمر

\begin{tabular}{|c|c|c|}
\hline \% & التكرار & المتغيرات \\
\hline rч.. & 70 & الصف الأول الثانوي \\
\hline Tr.. & $\wedge$. & الصف الثاني الثانوي \\
\hline$\varepsilon r_{.} \cdot$ & 1.0 & الصف الثالث الثانوي \\
\hline$\% 1 \ldots$ & ro. & المجموع \\
\hline
\end{tabular}

تشـير بيانـات الجـدول السـابق الـى توزيـع أفراد العينـة حسـب المسـتويات الاكثر ممارسـة 
في المجتمع وتعتبر وسـائل التكنولوجيـا مـن أهم وسائط الاتصال الحديثة التي تستطيع أن تسيطر ولئر على الأفراد والجماعات والدول في غالبية أنحاء

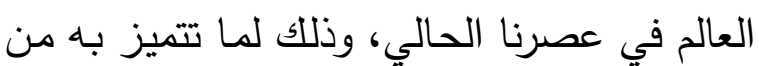

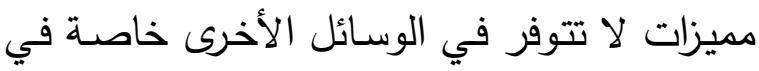

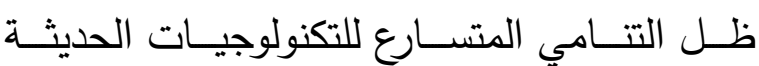

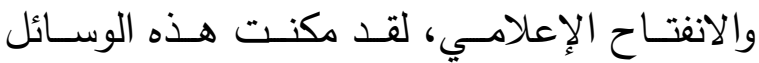
الإنسان من اختصـار المكان والزمان، باستعمالها تقنيـات متطورة كالأقمار الصناعية والتليفزيونيـة. إن استخدام وسائل التكنولوجيا الحديثة كان له دوراً كبيراً في تتامي العنف في المجتمع ، وذلك من

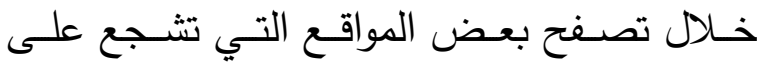

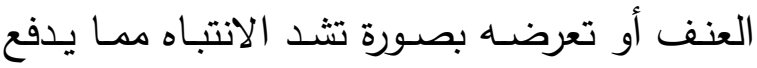

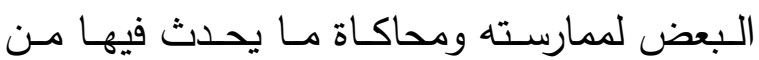

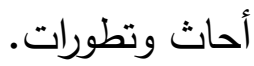

جدول رقم (11)

توزيع أفراد العينة حسب السبب الرئيسي لظاهرة

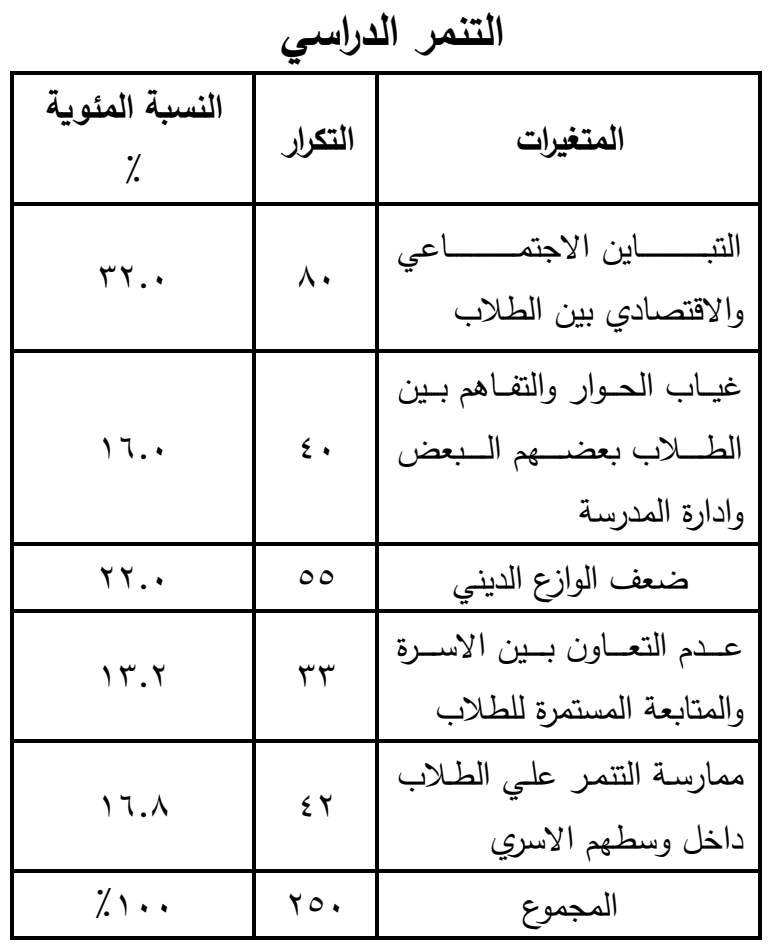

تثـير بيانـات الجدول السـابق الـى توزيـع

أفراد العينـة حسب نوع التتمر المدرسي الذي لئي

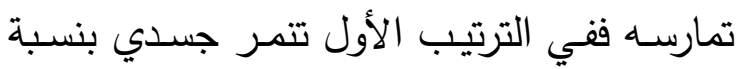
^^. . .

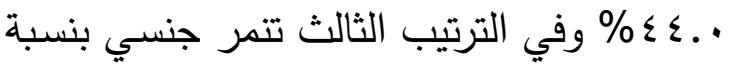
.$\% \wedge$.

نستتتج من السابق أن العنف الجسدي من

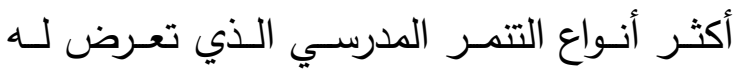
الغالبية العظمى من عينة الدراسة. ويعرف التتمر الجسدي بأنه الضرب والركل بالقدم واللكم بقبضة اليد والخنق والقرص والعض العرد الفربن وغيرها من الأفعال البذيئة.

$$
\text { جدول رقم (· (1) }
$$

توزيع أفراد العينة حسب مساهمة التكنولوجيا الحديثة في بروز وانتشار ظاهرة التنمر

\begin{tabular}{|c|c|c|}
\hline \multicolumn{3}{|c|}{ المدرسسي } \\
\hline النسبة المئوية ٪ & التكرار & المتغيرات \\
\hline $07 .$. & $1 \leqslant$. & نعر \\
\hline rr.e & $\Lambda$. & الي حد ما \\
\hline Ir.. & r. & $y$ \\
\hline$\% 1 \ldots$ & ro. & المجموع \\
\hline
\end{tabular}

تثـير بيانـات الجدول السـابق الـى توزيـع أفراد العينة حسب مسـاهمة التكنولوجيا الحديثة

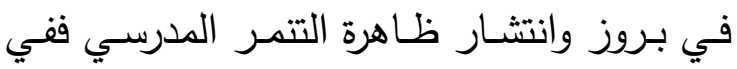

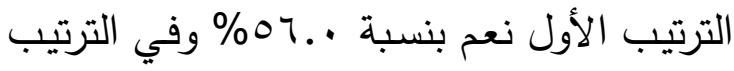

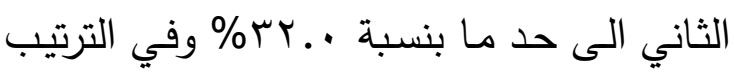

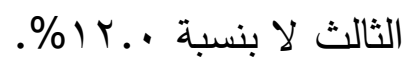

نستتنج من السـابق أن للتكنولوجيا الحديثة دور في بروز وانتشـار ظـاهرة التنــر المدرسي كيدي 
تثير بيانات الجدول السابق الى توزيع أفراد العينة حسب الاكثر ممارسة للتتمر الدرسي ففي لباني

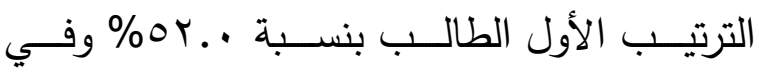
الترتيب الثاني المعلم بنسبة . ـrr\% وفي الترتيب الثالث إدارة المدرسة بنسبة .ـ1 (1\%. نسـتنتج ممـا سـبق أن الطالـب مسن أكثر الأشخاص ممارسة للتمر المدرسي يليه المعلم ثم الإدارة المدرسية. وتتدرج هذه تحت "التتمر المدرسي الثامل"، حيث نظـام المدرسـة مضطرب بأجمعسه وتسـوده حالة من عدم القدرة والسيطرة على ظاهرة التتمر

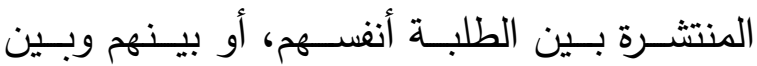
معلميهم، وتسـمع العديــــــن الثـكاوى مـن قبـل

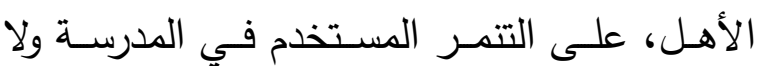
يستطيعون السيطرة عليه.

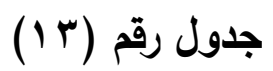

توزيع أفراد العينة حسب أسباب ممارسة التنمر

\begin{tabular}{|c|c|c|}
\hline \multicolumn{3}{|c|}{ في المدرسة } \\
\hline $\begin{array}{c}\text { النسبة المئوية } \\
\text { \% }\end{array}$ & التكرار & المتغيرات \\
\hline $1 \leqslant .$. & ro & 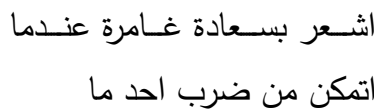 \\
\hline $17 .$. & $\varepsilon$. & اريده حتي لو بالعنف الـي كل مـا \\
\hline หч.. & 70 & 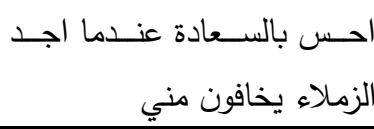 \\
\hline r..r & or & المشاركة في الشجار معهم استداء زملائي \\
\hline rr.A & or & العنفيص شخصيات ابطال افلام \\
\hline$\% 1$. & ro. & المجموع \\
\hline
\end{tabular}

تشير بيانـات الجـدول السـابق الـى توزيـع أفراد العينة حسب السبب الرئيسي لظاهرة التتمر

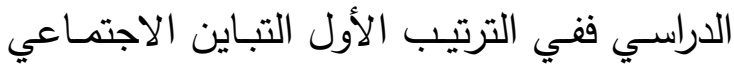

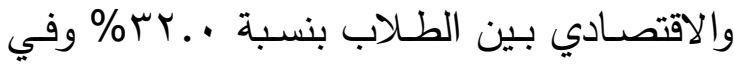
الترتيـب الثـاني ضــف الــوازع الــيني بنسـبة

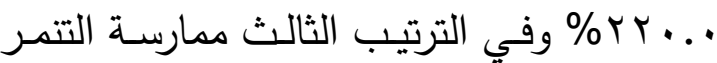
علـي الطـلاب داخـل وسـطهم الاســري بنسـبة

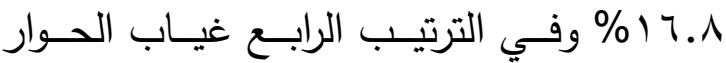
والتفــاهم بـين الطـلاب بعضـهم الـبعض وادارة

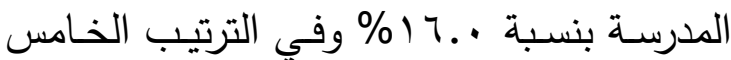
عـدم التعـاون بـين الاسـرة والمتابعـة المسـتمرة

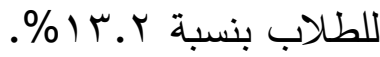

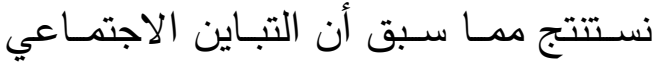

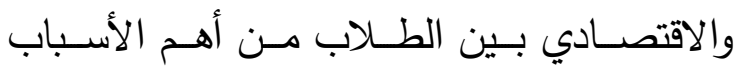

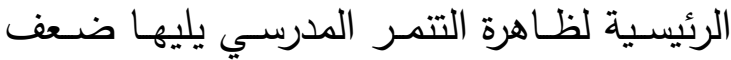
الوازع الـيني ثم ممارسـة التنمر على الطـلاب داخـل وسـطهم الأسـري كـذلك غيـاب الـــوار والتفــاهم بـين الطـلاب بعضــهم الـبعض وإدارة

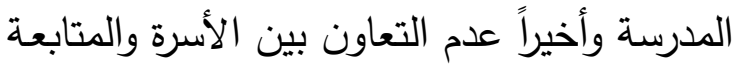
المستمرة للطلاب.

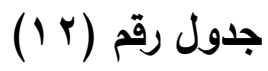

\begin{tabular}{|c|c|c|}
\hline \multicolumn{3}{|c|}{ المدرسي } \\
\hline النسبة المئوية \% & التكرار & المتغيرات \\
\hline or.. & Ir. & الطالب \\
\hline Tr.. & $\wedge$. & المعلم \\
\hline 17. & $\varepsilon$ & ادارة المدرسة \\
\hline$\% 1 \ldots$ & ro. & المجموع \\
\hline
\end{tabular}

توزيع أفراد العينة حسب الاكثر ممارسة للتنمر 
تشير بيانات الجدول السابق الى توزيع أفراد

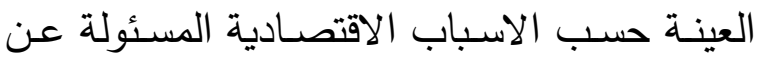
ممارسة الطلاب للتتمرالمدرسي ففي الترتيب الأول

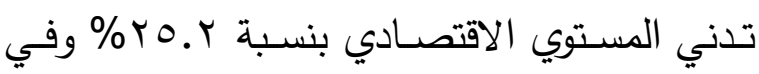
الترتيب الثاني عدم ملائمة دخل الاسرة للمتطلبات

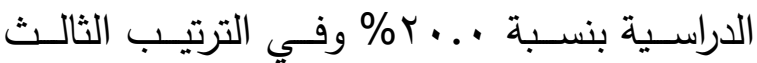
حرمان الطلبة من المساعدات مالية من المدرسـة

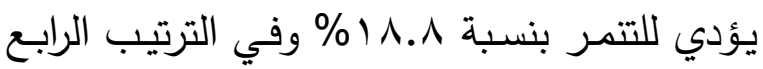
عدم وجود مورد مالي يكفي لاحتياجات الطالب بنسبة .؛؛ (1\% وفي الترتيب الخـامس الحرمـان

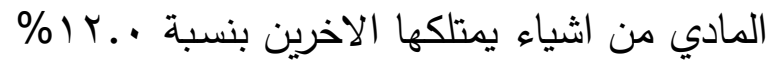
وفـي الترتيـب السـادس ازديـاد ارتفـاع الاسـعار

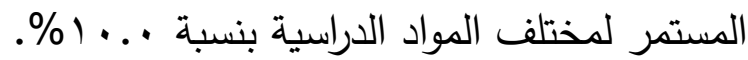
نستنتج مما سبق أن هناك أسباب اقتصادية

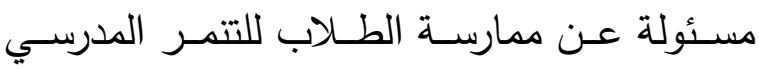
أهمهـا تـنـي المستوي الاقتصـادي وعدم ملائمسـة دخل الاسـرة للمتطلبـات الدراسية وحرمـان الطلبة الطبة من المساعدات المالية من المدرسة يؤدي للتتمر

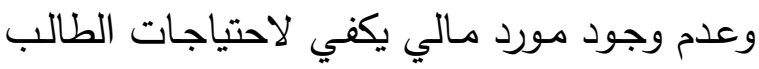
والحرمـان المـادي مـن اشـياء يمتلكهـا الاخـرين وازدياد ارتفاع الاسـعار المستمر لمختلف المواد

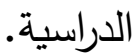

تشـير بيانـات الجدول السـابق الـى توزيـع

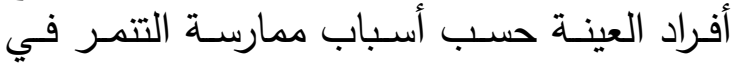

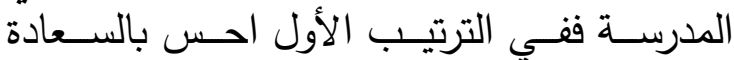

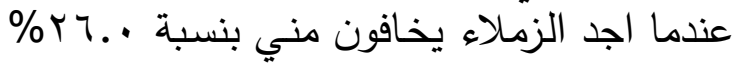

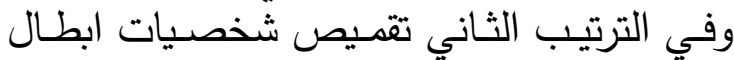

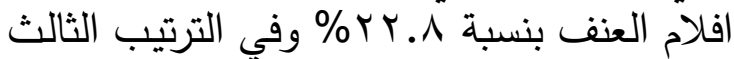

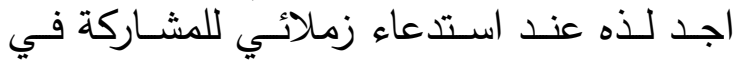

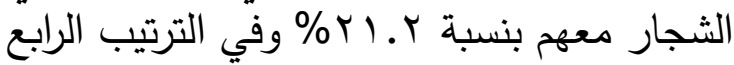

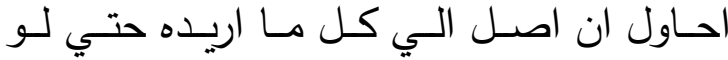

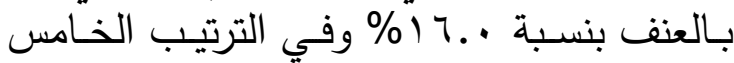
اشعر بسعادة غامرة عندما اتمكن من ضرب الترب احد الدي

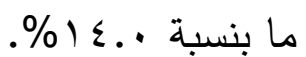

نسـتنتج ممـا سـبق أن الإحسـاس بالسـعادة

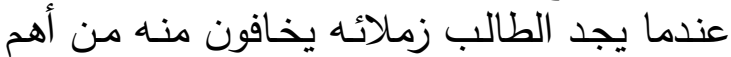

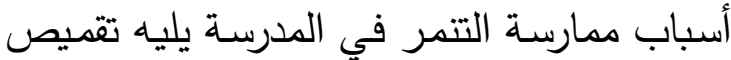

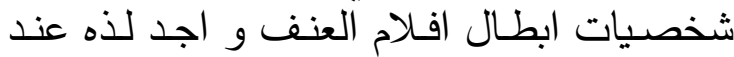

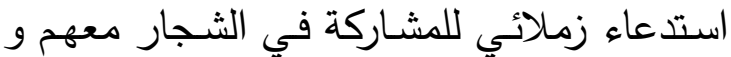

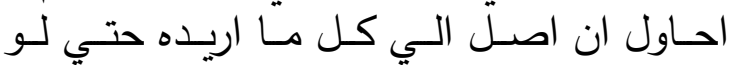
بالعنف والشعور بسعادة غامرة عندما اتمكن من اهن

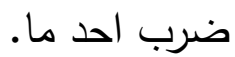

\section{جدول رقم (؛ أ)}

توزيع أفراد العينة حسب الاسباب الاقتصادية المسئولة

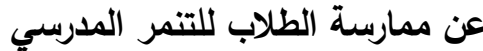

\begin{tabular}{|c|c|c|}
\hline $\begin{array}{c}\text { النسبة المئوية } \\
\text { \% }\end{array}$ & التكرار & المتغيرات \\
\hline $1 \varepsilon .$. & ro & عاحتياجات الطالب مالي يكفي \\
\hline$r \ldots$ & 0. & للمتطلبات الدراسية دخلـ الاســرة \\
\hline $1 \cdots$ & ro & 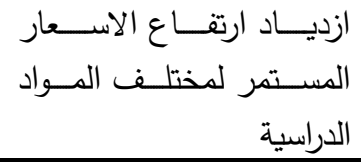 \\
\hline IY.. & $r$. & يمتلكها الاخربن المسادي من اشياء \\
\hline ro.r & זי & تدني المستوي الاقتصادي \\
\hline 11.1 & $\varepsilon v$ & 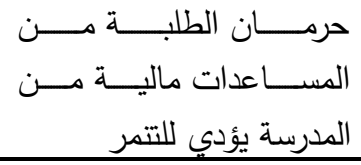 \\
\hline \%... & ro. & المجموع - المع \\
\hline
\end{tabular}


جدول رقم (17)

توزيع أفراد العينة حسب تأثير جماعة الرفاق في ممارسة التنمر

\begin{tabular}{|c|c|c|}
\hline النسبة المئوية \% & التكرار & المتغيرات \\
\hline Y^.. & $v$. & تشجيع الرفاق علي \\
\hline$r \cdot$. & 0. & 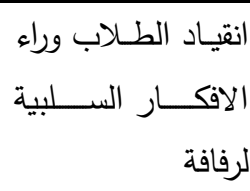 \\
\hline IT.. & r. & 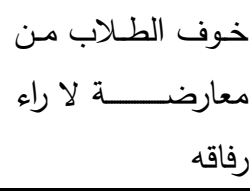 \\
\hline$r . .$. & vo & حماعة الرفاقرة مع \\
\hline $1 \ldots$ & ro & 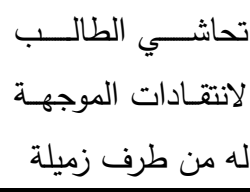 \\
\hline$\% 1 \ldots$ & ro. & المجموع \\
\hline
\end{tabular}

تشير بيانات الجدول السابق الى توزيع أفراد

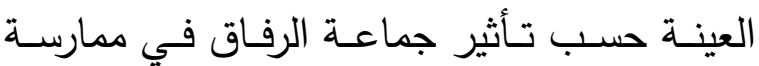
التتمر ففي الترتيب الأول حب المغامرة مع جماعة

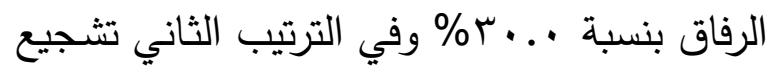

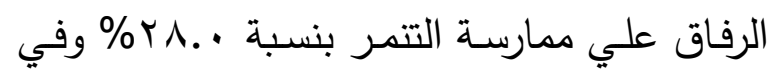
الترتيب الثالث انقياد الطلاب وراء الافكار السلبية

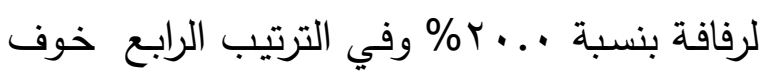

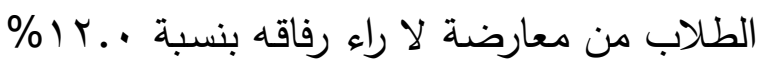
وفي الترتيب الخامس تحاشي الطالب لانتقادات الموجهة له من طرف زميلة بنسبة ... (1\%.

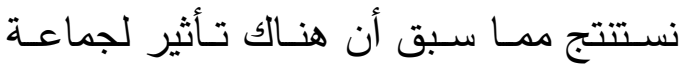

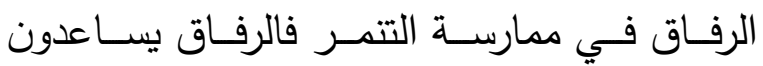

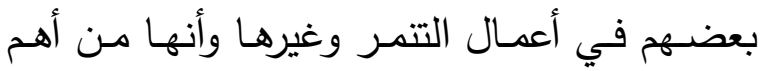

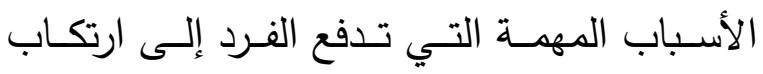

جدول رقم (10)

توزيع أفراد العينة حسب الأسباب النفسية المسئولة عن ممارسة الطلاب للتنمر المدرسي

\begin{tabular}{|c|c|c|}
\hline النسبة المئوية ٪ & التكرار & المتغيرات \\
\hline$r \cdot . \cdot$ & 0. & الشعور بالنقص \\
\hline $11 .$. & $\leq 0$ & انعدام الثقة بالنفس \\
\hline$r \varepsilon .$. & 7. & الانزعاج من كثرة \\
\hline Ir.e & $r$. & صعوبة تحمل مواقف \\
\hline r... & 70 & الشعور بقلة الاحترام \\
\hline$\% 1 \ldots$ & ro. & المجموع \\
\hline
\end{tabular}

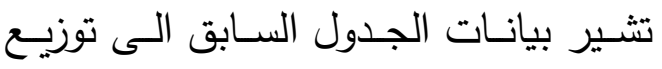

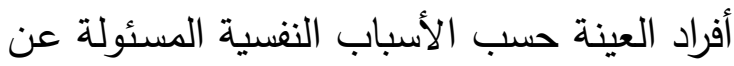

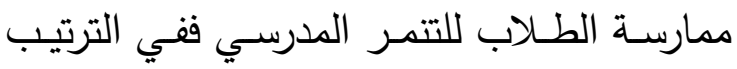

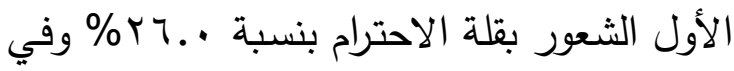

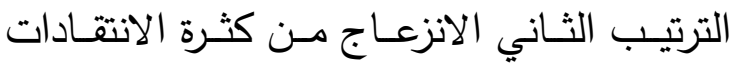

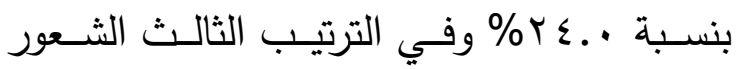

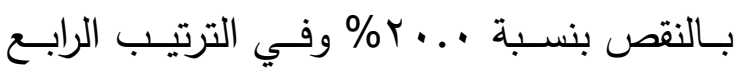

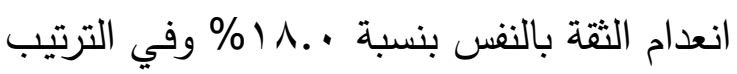
الخامس صسوبة تحمل مواقف الاحباط بنسبة .\%।r..

نستتنتج ممـا سبق تعدد الأسباب النفسية المسئولة عن ممارسـة الطلاب للتنمر المدرسي الهي

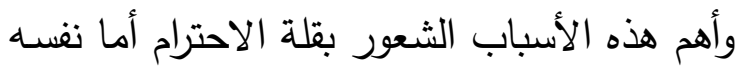
وأصدقائه وكذلك الانزعاج من كثرة الانتقادات وانعدام الثقة بالنفس والثعور بالنقص وصعوبة تحمل مواقف الإحباط. 
تشير بيانات الجدول السابق الى توزيع أفراد

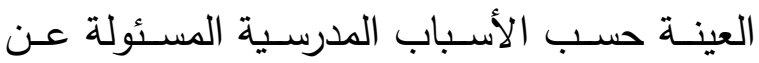

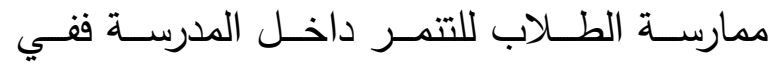
الترتيب الأول عدم وجود امـاكن مجهزة للترويح

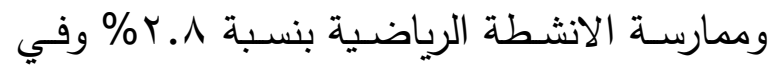
الترتيب الثاني تراخي المدرسة في معالجة مظاهر

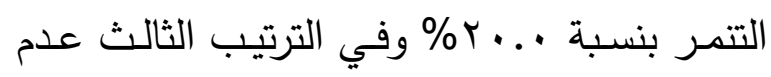
تطـرق المنـاهج الدراسية لمعالجـة اسـباب التنــر

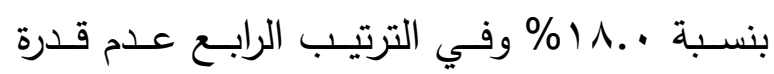

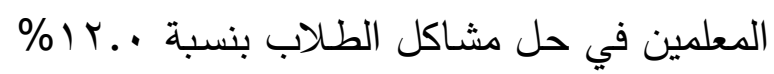
وفي الترتيب الخـامس ضــف اللـوائح والقوانين

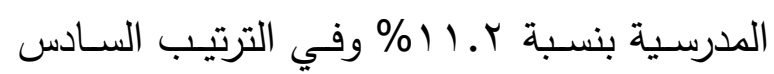
عدم مقدرة الادارة المدرسية علي توفير جو ملائم للطلاب بنسبة ... 1 \% وفي الترتيب السابع تأثر

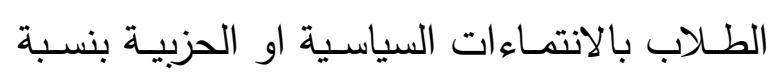

$$
\text { .\%^. . }
$$

نستتتج مما سبق أن هناك أسباب مدرسية مسئولة عن ممارسة الطلاب للتتمر داخل المدرسة

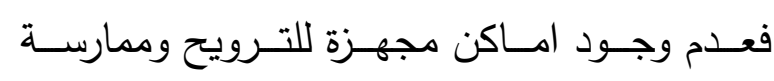
الانشطة الرياضية وتراخي المدرسـة في معالجـة

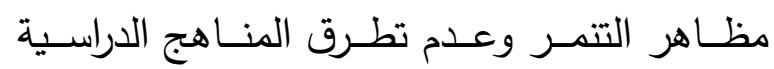
لمعالجة اسباب التتمر وكذلك عدم قدرة المعلمين في حل مشاكل الطلاب وضعف اللوائح والقوانين المدرسية وعدم مقدرة الادارة المدرسية علي توفير جو ملائـم للطـلاب وتـأثر الطـلاب بالانتهـاءات السياسية او الحزبية.
الأفعـال السـلوكية الإجراميـة اختلاطـهـ وتجاوبـهـ

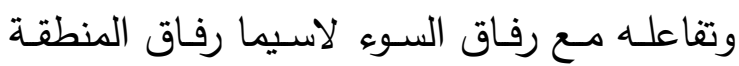
السكنية ورفاق المدرسة من المنحرفين والأشرار

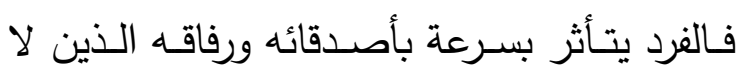

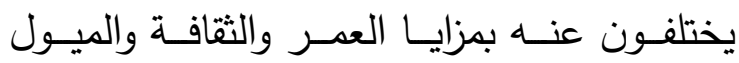
والاتجاهات والأذواق حيث انه يتأثر برفاقه أكثر بران مما يتأثر بابيه أو أمه أو مدرسته. وعندما تكون

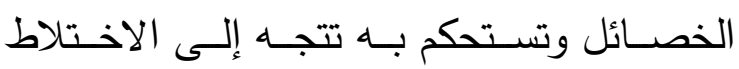
والتفاعل بحيث تجعله شـاذ ومنحرف في أفكاره وممارسته اليومية وهنا لا تستطيع العائلة ولا أية مؤسسة أخرى في المجتمع من إصـلاحه وتقويم

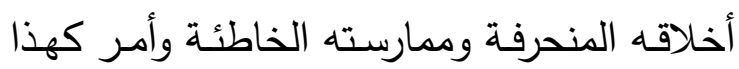

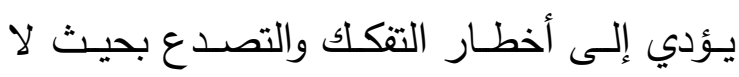
تستطيع العائلة هنا القيام بوظائفها ومهامها تجاه

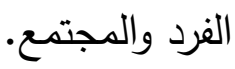
جدول رقم (IV)

توزيع أفراد العينة حسب الأسباب المدرسية المسئولة

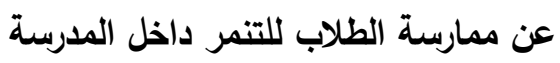

\begin{tabular}{|c|c|c|}
\hline المئوية \% & 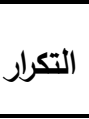 & المتغيرات \\
\hline $1 \wedge .$. & $\leqslant 0$ & عدم تطرق المناهج الدراسية لمعالجة \\
\hline$r \ldots$ & 0. & تراخي المدرسـة في معالجة مظاهر \\
\hline$r \cdot . \Lambda$ & Or & وممارسة الانشطة الرياضية مجهزية للترويح \\
\hline $1 \cdots$ & ro & توفير جو مقدرة الادارة المدرسـية علـي \\
\hline IT.. & $r$. & عدم قدرة المعلمين في حل مشـاكل \\
\hline $11 . r$ & rA & ضعف اللوائح والقوانين المدرسية \\
\hline А.. & $r$. & تأثر الطلاب بالانتماءات السياسية \\
\hline$\% 1 \ldots$ & ro. & المجموع \\
\hline
\end{tabular}


ضـد المدرّسـين والمـدراء فينتج عـن ذلك طالب مشرد مستهتر غير مهتم بأي شيء يمتلك كثير من الصفات والخصال غير المرغوب فيها. جدول رقم (19 ) - (19)

توزيع أفراد العينة حسب الاثار السلبية للتنمر

\begin{tabular}{|c|c|c|}
\hline \multicolumn{3}{|c|}{ المدرسي علي الطلاب } \\
\hline المئوية \% النسبة & التكرار & المتغيرات \\
\hline r... & ᄉ. & 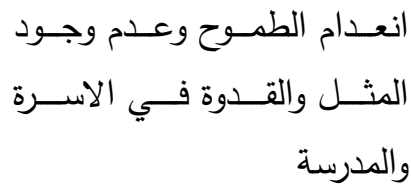 \\
\hline r^.. & $V$. & 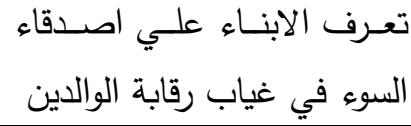 \\
\hline r... & 00 & شالاحباط والحقد علي الاخرين \\
\hline $11 .$. & $\leqslant 0$ & 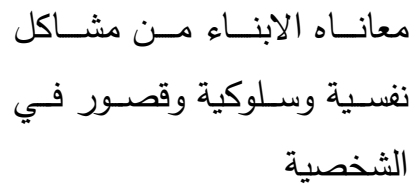 \\
\hline$\% 1 \ldots$ & ro. & المجموع \\
\hline
\end{tabular}

تشير بيانات الجدول السـابق الى توزيع أفراد العينـة حسب الاثار السلبية للتنمر المدرسي علي الطـلاب ففي الترتيب الأول انعدام الطموح وعدم وجـود المثل والقدوة في الاسـرة والمدرســة بنسـبة . . . . . وفي الترتيب الثاني تعرف الابناء علي اصـدقاء السـوء في غيـاب رقابـة الوالـدين بنسـبة \% . . . بـالنقص والاحبـاط والحقـــ علي الاخـرين بنسـبة

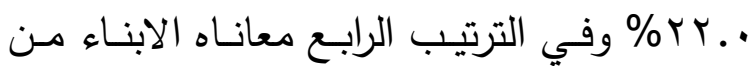
مشـاكل نفسـية وسـلوكية وقصـور في الشخصـية

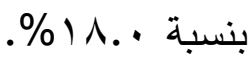

جدول رقم (1^) - (1^)

توزيع أفراد العينة حسب أن التنمر المدرسي يؤثر بثكل كبير على شخصية الطلاب

\begin{tabular}{|c|c|c|}
\hline النسبة المئوية ٪ & التكرار & المتغيرات \\
\hline 07. & $1 \leqslant$. & نعم \\
\hline r^.. & V. & نوعا ما \\
\hline 17. & $\varepsilon$. & $y$ \\
\hline$\% 1 \ldots$ & Yo. & المجموع \\
\hline
\end{tabular}

تشـير بيانـات الجـدول السـابق الـى توزيـع أفـراد العينــة حسـب أن التنمـر المدرسـي يـؤثر بشكل كبير على شخصية الطلاب ففي الترتيب الأول نعـ بنسبة . . ـ\%\% وفي الترتيب الثاني

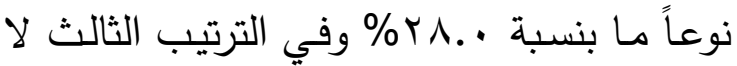
بنسبة . .7 (1).

نستتتج مدا سبق أن التتمر المدرسي يؤثر بشكل كبير على شخصية الطالب فيُعتبر التنمر المَدرسيّ من الهِّفات غير المقبولة اجتماعياً، فالمجتمع يرفض مثل هذه السلوكيّات وينبذها بل وينبذ صـاحبها، كما أنَّ الأهالي لا يقبلون بمثل هذه السـلوكيات تجـاه أطفـالهم. نتيجـة الانفتـاح الكبيـر أصـبح العنـف المدرسـي يُقابـل بنـوع مـن المحاسـبة، فلـم يعـد يتقبَّل الأهـالي أي نـوعٍ مـن

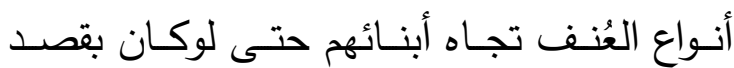

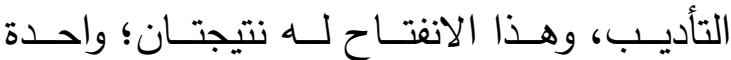
إيجابية، حيث إنَّ المعلمين والمدراء المتسلِّطين أصبح هناك من يحاسِبهم ويوقفهم عن ممارسـة العنـف ضــــ الطـلاب، ولكن في نفس الوقت أصـبح هنـالك تمـادٍ مـن بعـص الطـلاب على المعلمـين والمدراء، وظهـر العنف مـن الطـلاب 
الثالث الثـعور بـالخوف والنبـ مـن قبـل المجتمع

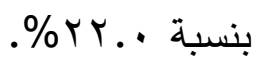

من السـابق يتضـح أن هنالك أبعاد اجتماعية

للتنمر المدرسي أهمها إجـاد صسعوبات كبيره في كي

التكيف، وإقامة علاقات اجتماعية سليمة ومتوافقة والثـعور بالعزلـة ، والانطـواء والانسـاب ، والتي

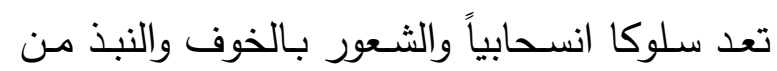

قبل المجتمع.

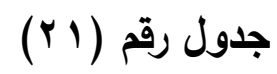

توزيع أفراد العينة حسب الابعاد الاقتصادية

\begin{tabular}{|c|c|c|}
\hline المئوية \% النسبة & التكرار & المتغيرات \\
\hline$r \varepsilon_{.}$ & 10 & هدر المال العام \\
\hline$\varepsilon \cdot$. & $1 \ldots$ & 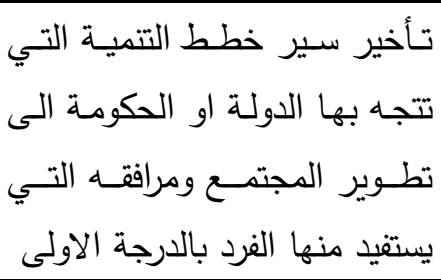 \\
\hline rч.. & 70 & ما لعبـث بعالمرافق والامـاكن العامـة \\
\hline$\% 1 \ldots$ & ro. & المجموع \\
\hline
\end{tabular}

تشـير بيانـات الجـدول السـابق توزيــع أفـراد

العينة حسب الابعـاد الاقتصـادية للتنمر المدرسي

ففي الترتيب الأول تأخير سير خطط التتمية التي تتجهـ بها الدولة او الحكومـة الى تطوير المجتمـع ومرافقـه التي يسـتفيد منهـا الفـرد بالدرجـة الاولى لـى بنسبة . . • ع\% وفي الترتيب الثاني هدر المسال العام بنسبة . .ـ؟٪\% وفي الترتيب الثالث العبث بالمرافق والاماكن العامة مما يعرقل تطويرها بنسبة
نستتتج مما سبق أهم الآثار السلبية للتتمر

المدرسـي على الأبنـاء ومـن هـذه الآثار انعدام

الطهـوح وعـدم وجـود المثل والقـدوة في الاسـرة والمدرسة وتعرف الابناء علي اصدقاء السوء في غيـاب رقابـة الوالـدين وشـعور الابنـاء بـالنقص والاحبـاط والحقد علي الاخرين ومعانـاه الابنـاء مـن مشــاكل نفسـية وســلوكية وقصــور فـي الشخصية.

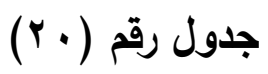

توزيع أفراد العينة حسب الابعاد الاجتماعية

\begin{tabular}{|c|c|c|}
\hline المئوية \% & التكرار & المتغيرات \\
\hline$\varepsilon r_{.} \cdot$ & 1.0 & 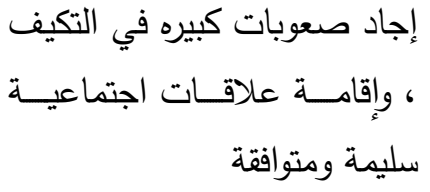 \\
\hline Tr.. & 00 & الشتعور بالخوف والنبذ من قبل \\
\hline rч.. & 9. & 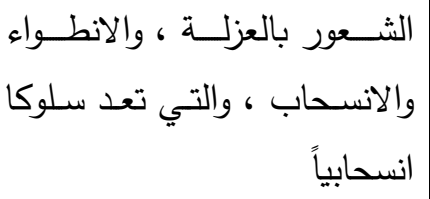 \\
\hline$\% 1 \ldots$ & ro. & المجموع \\
\hline
\end{tabular}

تشـير بيانـات الجـدول السـابق الـى توزيـع

أفراد العينــة حسـب الابعـاد الاجتماعيـة للتنمـر المدرسي ففي الترتيب الأول إجاد صعوبات كبيره في التكيف ، وإقامسة علاقـات اجتماعيـة سـليمة

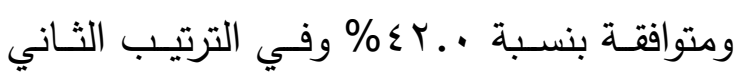
الشعور بالعزلة ، والانطواء والانسحاب ، والتي تعد سلوكا انسحابياً بنسبة . . بـ\% وفي الترتيب

$$
\text { .\%rт. . }
$$




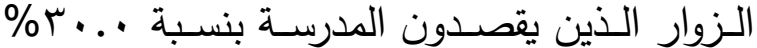
وفـي الترتيــب الثـاني تــنـي مســتوي المكانـــة الاجتماعيـة للأسـرة بنسبة . . بr\% وفي الترتيب الثالث تدني المستوي الثقافي والفكري للأبناء البلد الذي تكثر فيـه هذه الممارسـات العدوانيـة خاصـة على الأمـاكن الأثريـة منهـا أو التاريخيـة بنسـبة

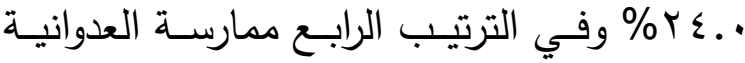
تجـاه الممتلكات العامـة فعل غير حضـاري يشـوه

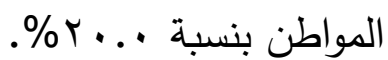

نستتتج مما سبق أن هنالك أبعاد ثقافية للتنمر المدرسـي ومـن هذه الأبعـاد النظـرة السـلبية تجـاه ممارس هذا السلوك من ابناء المجتمع ومن الزوار الـين يقصـدون المدرسـة وتـنـي مسـتوي المكانـة الاجتماعية للأسرة وتدني المستوي الثقافي والفكري

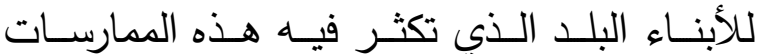
العدوانيـة خاصـة على الأمساكن الأثربـة منهـا أو التاريخية وممارسة العدوانية تجاه الممتلكات العامة فعل غير حضاري يشوه المواطن.

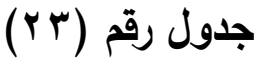

توزيع أفراد العينة حسب الدور البارز للمؤسسات الحكومية والاهلية في محاربة مشكلة وظاهرة

\begin{tabular}{|c|c|c|}
\hline النسبة المئوية ٪ & التكرار & المتغيرات \\
\hline $07 .$. & $1 \varepsilon$. & متاز \\
\hline$\varepsilon \varepsilon \ldots$ & 11. & الي حد ما \\
\hline$\cdots$ & - & $\gamma$ \\
\hline$\% 1 \ldots$ & ro. & المجموع \\
\hline
\end{tabular}

تشير بيانات الجدول السـابق الى توزيع أفراد العينـة حسب الـدور البـارز للمؤسسـات الحكوميـة
نســتنتج مدــا ســبق اخـتلاف الابعــاد الاقتصـادية للتمـر المدرسي فمنها تأخير سـير خطط التتمية التي تتجه بها الدولة او الحكومـة الحى تطوير المجتمـع ومرافقـه التي يستتيد منها الفرد بالدرجـة الاولى وهدر المـال العـام والعبث بالمرافق والاماكن العامة مما يعرقل تطويرها.

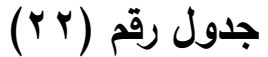
توزيع أفراد العينة حسب الابعاد

\begin{tabular}{|c|c|c|}
\hline المئوية \% النسبة & التكرار & المتغيرات \\
\hline$r \cdot . \cdot$ & vo & 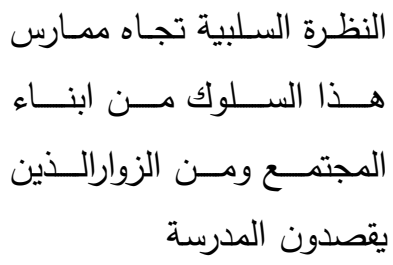 \\
\hline$r \varepsilon .$. & 7. & 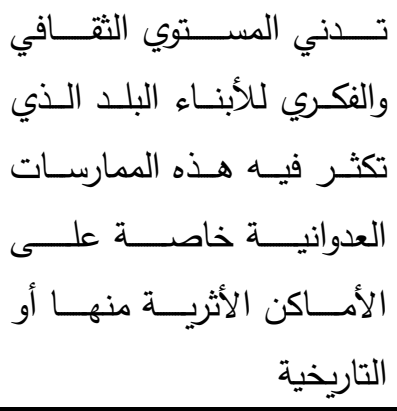 \\
\hline r... & 70 & 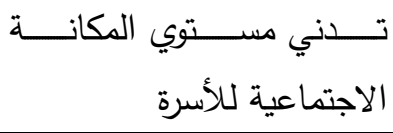 \\
\hline$r \cdot$. & 0. & 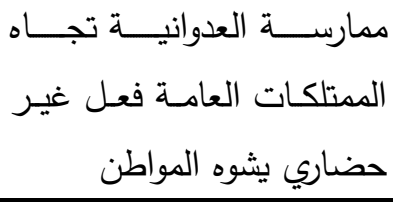 \\
\hline$\% 1 \ldots$ & ro. & المجموع \\
\hline
\end{tabular}

تشـير بيانـات الجـدول السـابق الـى توزيـع أفــراد العينــة حســب الابعــاد الثقافيــة للتنـــر المدرسي ففي الترتيب الأول النظرة السلبية تجاه مهـارس هـذا السـلوك مـن ابنـاء المجتمـع ومهن 


\begin{tabular}{|c|c|c|}
\hline$r \cdot . \Lambda$ & Or & 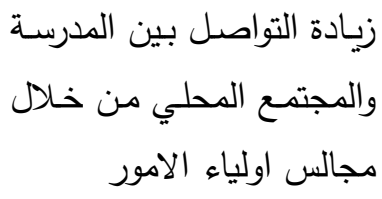 \\
\hline IY.s & r & 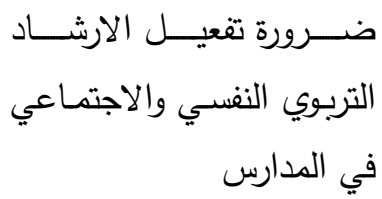 \\
\hline$\% 1 \ldots$ & ro. & المجموع \\
\hline
\end{tabular}

تشير بيانات الجدول السـابق الى توزيع أفراد العينـة حسب التدابير الوقائيـة التي من شـأنها ان تحد من التتمر المدرسي ففي الترتيب الأول زيادة التواصل بين المدرسة والمجتمع المحلي من خلال

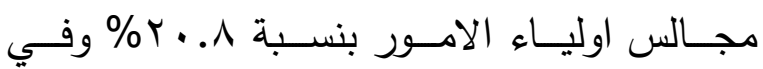
الترتيب الثاني مساعدة الطالب علي التخلص من أزماته وتصـيح مفاهيمهه وعاداته الخاطئة بنسبة

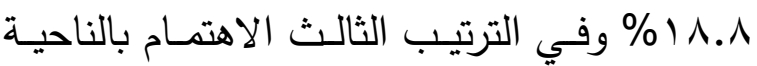
النفسية للطالب العدواني عن طريق المتابعة داخل المدرســة والاسـرة بنسـبة . .1 ا \% وفي الترتيـب الرابــع ضــرورة تفعيـل الارشــاد التربـوي النفسـي

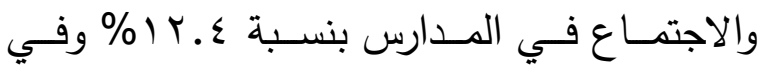
الترتيب الخامس تطوير التعليم والمناهج والاهتمام

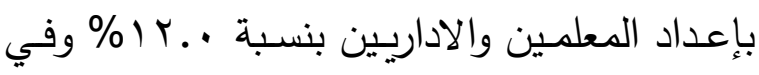
الترتيـب السـادس تحويـل الصـف الدراسـي والبيئة المدرسية الي بيئة مريحة امنة تشجع علي الابداع بنسبة . . . 1\% وفي الترتيـب السـابع معرفة مـا يعـاني منـه الطالب مـن مشكلات ومحاولـة حلها

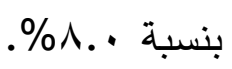

نستتتج مما سبق أن هناك تدابير وقائية التي من شأنها ان تحد من التنمر المدرسي في مقدمتها

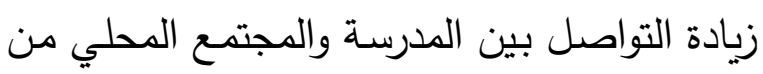
خـلال مجـالس اوليـاء الامسور ومسـاعدة الطالب لبـ
والاهليـة في محاربـة مشـكلة وظــاهرة التتمـر

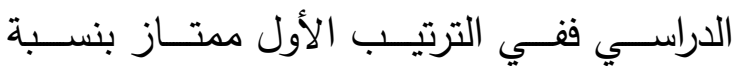
، . . . . $\% \varepsilon \varepsilon$. . نسـتتتج مـن السـابق أن هنـالك دور بـارز للمؤسسات الحكومية والأهلية في محاربـة مشكلة وظاهرة التتمر المدرسي وأكدت الغالبية العظمى من عينة الدراسـة أنهه دور ممتاز تتخذه الحكومة للحد من هذه الظاهرة وانتشارها داخل المدارس.

$$
\text { جدول رقم (Y r) }
$$

توزبع أفراد العينة حسب التدابير الوقائية التي من شأنها ان تحد من التمر المدرسي

\begin{tabular}{|c|c|c|}
\hline النسبة & التكرار & المتغيرات \\
\hline IY.. & r. & 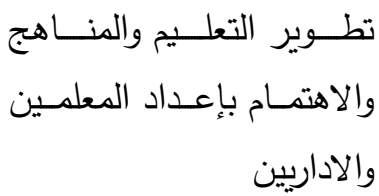 \\
\hline $1 \ldots$ & ro & 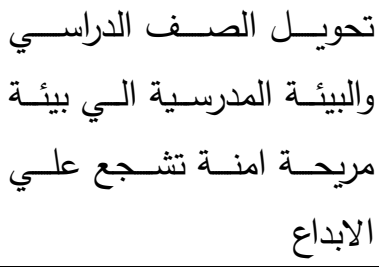 \\
\hline $1 \wedge$. & $\leqslant 0$ & اللاهتالب العـــام بالناحيــة النفسـية \\
\hline ᄉ.. & r. & معرفة ما يعاني منه الطالب \\
\hline $1 \wedge .1$ & $\varepsilon V$ & 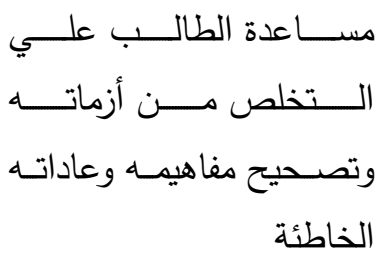 \\
\hline
\end{tabular}


مـن . . . ب بنسـبة . . . . وفي الترتيـب

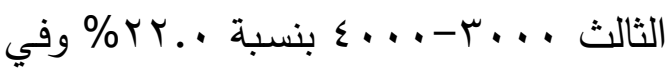
الترتيــب الرابـع ع . . . . . . بنســبة \%)^. .

0) أشـارت نتائج الدراسـة الميدانيـة الـى أسباب انتثـار التتمرداخـل المـدارس ففـي الترتيـب الأول أسـباب أسـرية بنسـبة . .ـ r\% وفي الترتيـب الثـاني أسـباب اجتماعيـة بنسـبة

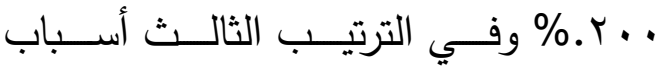

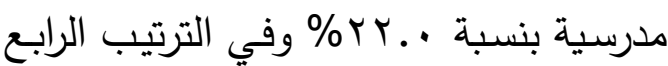
أســباب شخصـية بنســبة . .1 | \% وفـي الترتيـب الخـامس أسـباب اقتصـادية بنسـبة .$\% 17$. . 7) بينت نتائج الدراسـة الميدانية الطلاب الاكثر ممارسـة للتنمـر الدراسـي ففي الترتيب الأول المتــأخرين دراسـياً بنســبة . . . 7\% وفـي

الترتيب الثاني المتفوقين بنسبة . . ؟ \% .

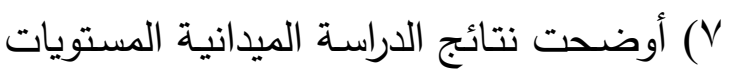
الاكثر ممارسة للتنمر الصف الثالث الثانوي

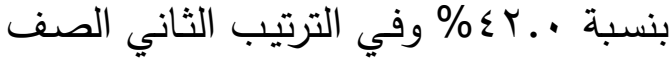
الثاني الثانوي بنسبة · . بr\% وفي الترتيب

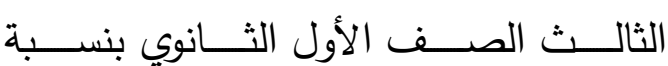
\% \%т. .

م) بينـت نتائج الدراسـة الميدانيـة مـدى انتشـار ظـاهرة التتمـر الدراسـي ففي الترتيـب الأول انتشـار سريع بنسبة . . م وفي الترتيب الثاني انتشار بطئ بنسبة . . . 9) أثـارت نتـائج الدراسـة الميدانيـة الـى نـوع التنمـر المدرسـي الذي يمارسـه أفراد العينـة
علي الـتخلص مـن أزماتـه وتصـحيح مفاهيمـه وعاداتـهـ الخاطئـة والاهتمــام بالناحيــة النفسـية للطالـب العـدواني عـن طريـق المتابعـة داخـل المدرسة والاسرة وضرورة تفعيل الارشاد التربوي النفسي والاجتماعي في المدارس وتطوير التعليم والمـاهج بأعـداد المعلمـين والاداريـين وتحويـلـ الصف الدراسي والبيئة المدرسية الي بيئة مريحة امنة تشجع علي الابداع ومعرفة ما يعاني منه الطالب من مشكلات ومحاولة حلها. عاشراً: النتائج العامة للبحث : () بينت نتائج الدراسـة نوع عينـة الدراسـة ففي

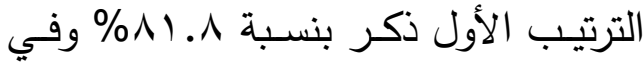

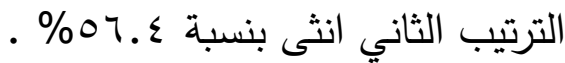
Y) أشـارت نتـائج الدراسـة الميدانيـة الى سـن عينة الدراسة ففي الترتيب الأول من 1 ا-

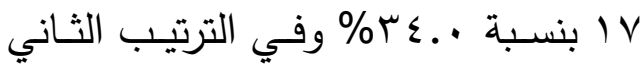

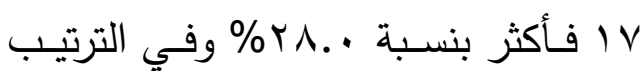

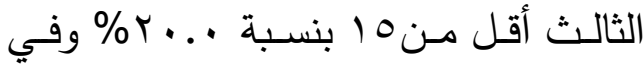
الترتيــب الرابــع مــن 0 1-7 1 بنســبة .\%।^. .

ץ) بينــت نتــائج الدراســة الميدانيــة الصــف الدراسي لعينة الدراسـة ففي الترتيب الأول الصف الثالث الثانوي بنسبة •... عـ وفي الترتيب الثاني الصف الثاني الثانوي بنسبة

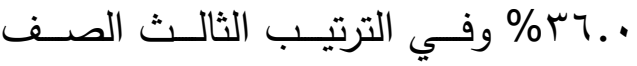

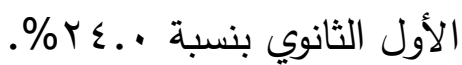

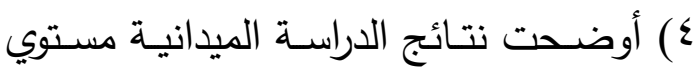
دخل الأسرة ففي الترتيب الأول . . . عفأكثر بنسـبة . . rr\% وفي الترتيب الثاني اقل 
r (1) أكدت نتائج الدراسة الميدانية على أسباب

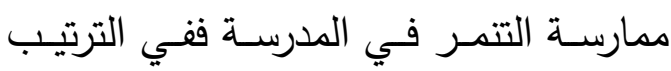

الأول احس بالسـعادة عندما اجـ الـزملاء

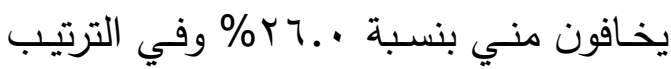

الثـاني تقــيص شخصـيات ابطــال افـلام

العنف بنسبة A.r\% و وفي الترتيب الثالث

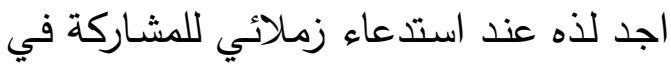

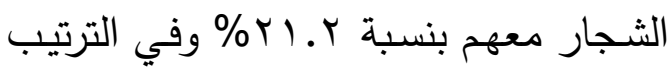

الرابع احاول ان اصل الي كل ما اريده حتي لـي

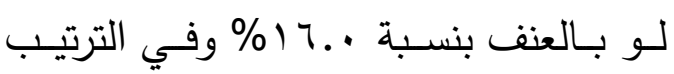

الخامس اشعر بسعادة غامرة عندما اتمكن

من ضرب احد ما بنسبة ..؟ (\%).

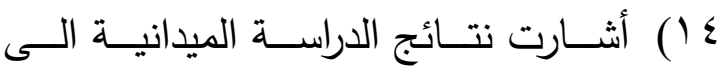

الاسباب الاقتصـادية المسئولة عن ممارسـة المانس

الطلاب للتتمر المدرسي ففي الترتيب الأول

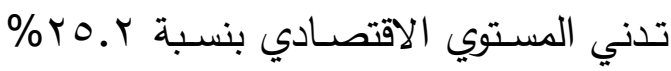

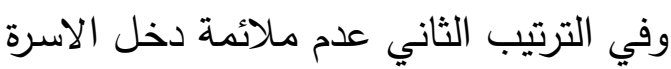

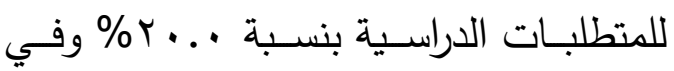

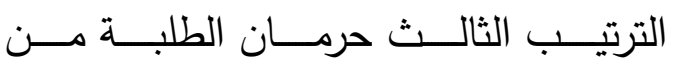

المساعدات مالية من الددرسة يؤدي للتتمر

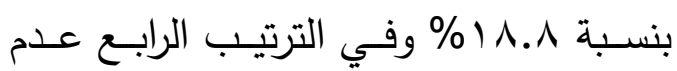

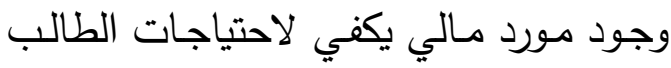

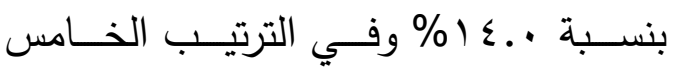
الحرمان المادي من اشياء يمتلكها الاخرين بنسبة . ب إ\% وفي الترتيب السادس ازدياد

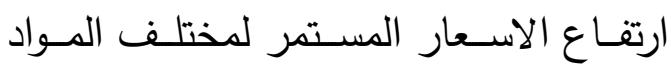

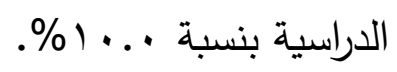

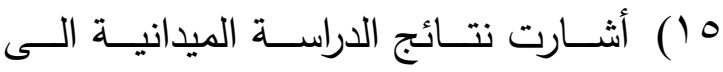

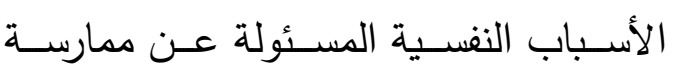

ففـي الترتيب الأول تتمـر جسـدي بنسـبة

^^. . .

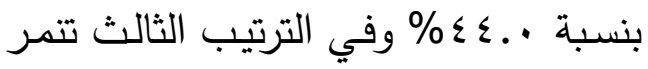

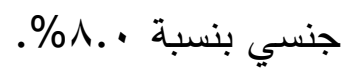

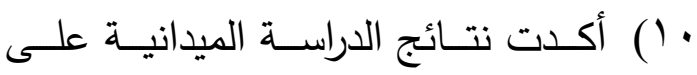

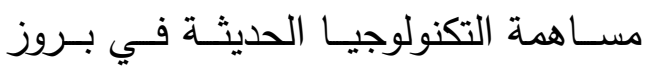

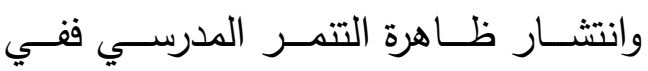

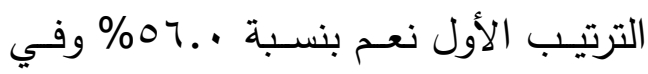

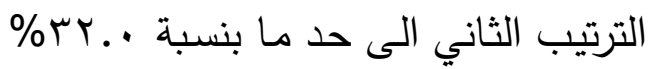

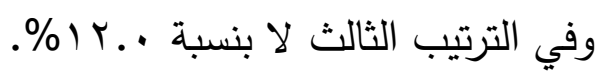

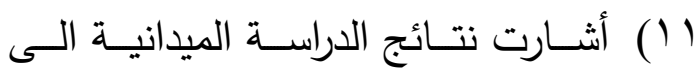
السبب الرئيسي لظاهرة التتمر الدراسي ففي

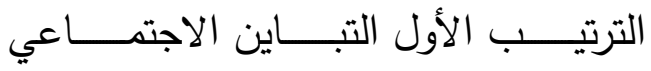
والاقتصادي بين الطلاب بنسبة . .بrr\% وفي الترتيب الثاني ضـعف الوازع الديني

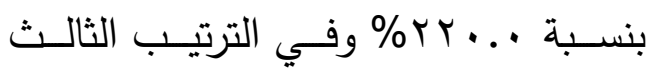

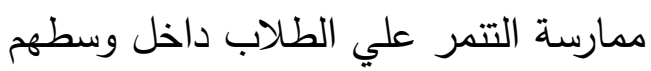
الاسري بنسبة ^. ا ا \% وفي الترتيب الرابع غياب الحوار والتفاهم بين الطلاب بعضهم

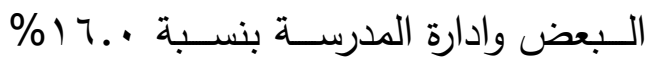
وفي الترتيب الخـامس عدم التعاون بين

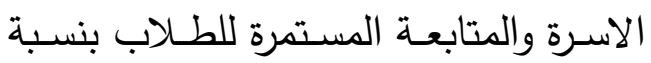
\% Ir.r Y I أكدت نتائج الدراسة الميدانية الى الفئات

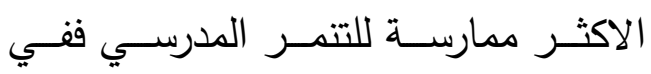

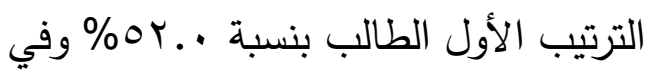

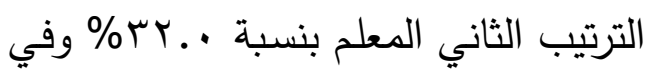

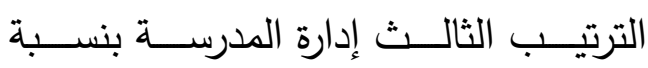
.\%17. 
الدراســية لمعالجـة اسـباب التمــر بنسـبة . . . . المعلمـين في حـل مشــاكل الطـلاب بنسـبة

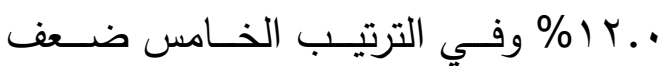

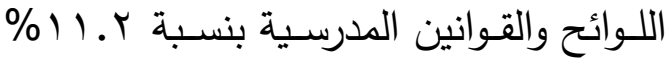
وفـي الترتيـب السـادس عـدم مقـدرة الادارة المدرسـية علـي تـوفير جـو ملائحم للطـلاب بنسـبة ... (1\% وفي الترتيـب السـابع تـأثر الطـلاب بالانتمـاءات السياسـية او الحزبيـة

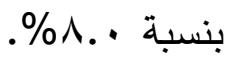
1 1 ) أوضحت نتائج الدراسة الميدانية أن التنمر المدرسـي يـؤثر بشكل كبير على شخصسية

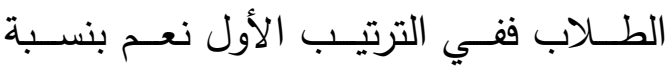
• . . . . 1 . . . $. \% 17 .$. 9 (1) أشـارت نتائج الدراسـة الميدانية الى الاثار السـلبية للتنمر المدرسي علي الطـلاب ففي الترتيـب الأول انعـدام الطمـوح وعـدم وجـود المثـل والقـدوة في الاسـرة والمدرسـة بنسـبة • . . . . علي اصدقاء السوء في غياب رقابة الوالدين

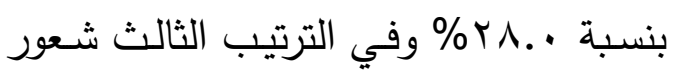

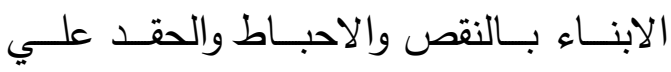
الاخرين بنسبة . . r.\% وفي الترتيب الرابع معانـاه الابنـاء مـن مشـاكل نفسـية وسـلوكية

وقصور في الثخصية بنسبة . ـ1 | \%. •

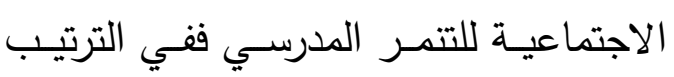

الطــلاب للتتمـر المدرسـي ففـي الترتيـب الأول الثـــور بقلـــة الاحتــرام بنســبة

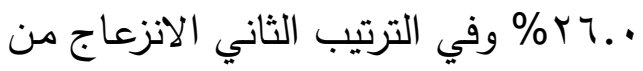

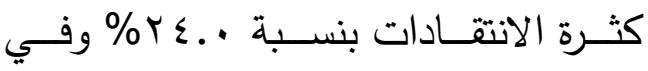
الترتيـب الثالـث الثـعور بـالنقص بنسـبة

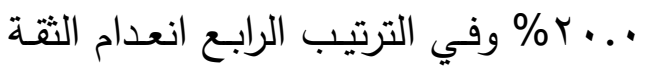
بـالنفس بنسـبة . .1 ا \% وفـي الترتيـب الخـامس صـعوبة تحمـل مواقف الاحبـاط

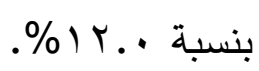

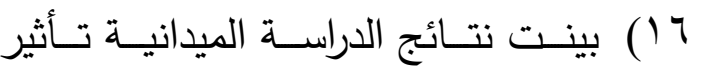
جماعـة الرفـاق في ممارســة التتمـر ففي لي الترتيـب الأول حـب المغـامرة مـع جماعـة الرفاق بنسبة . . . ٪\% وفي الترتيب الثاني تشجيع الرفاق علي ممارسـة التتمر بنسبة \% . . . الطلاب وراء الافكار السلبية لرفافة بنسبة \% وفـ ... . الطـلاب مـن معارضــة لا راء رفاقـه بنسـبة

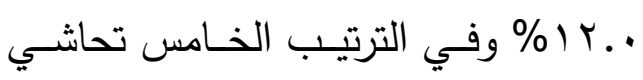
الطالب لانتقادات الموجهـة لـه من طرف زميلة بنسبة ... 1. 1. (IV الأسـباب المدرسية المسئولة عن ممارسـة الطلاب للتنمر داخل المدرسة ففي الترتيب الأول عـدم وجـود امـاكن مجهزة للترويح

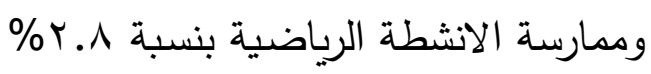
وفي الترتيب الثاني تراخي المدرسـة في

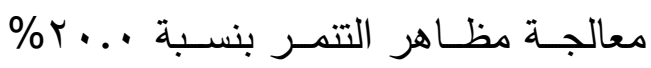
وفي الترتيب الثالث عدم تطرق المنـاهج 
الممتلكات العامـة فعل غير حضـاري يشـوه

$$
\text { المواطن بنسبة . . . r\%\%. }
$$

بץ) أشـارت نتائج الدراسـة الميدانيـة الى الدور له

البـارز للمؤسسـات الحكوميـة والاهليـة في

محاربـة مشكلة وظـاهرة التتمر الدراسي ففي

الترتيب الأول ممتاز بنسـبة ، . ـ4\% وفي

الترتيب الثاني الى حد ما بنسبة . .ع ؛ \%.

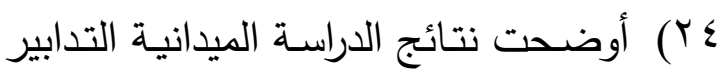

الوقائية التي من شـأنها ان تحد من التنمر

المدرسي ففي الترتيب الأول زيـادة التواصل مل فل

بين المدرسـة والمجتمـع المحلـي مـن خـلال

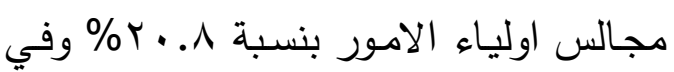

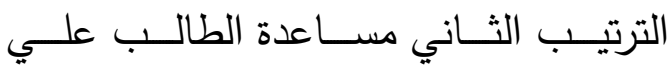
الـتخلص مـن أزماتـه وتصـــيح مفاهيمـهـ

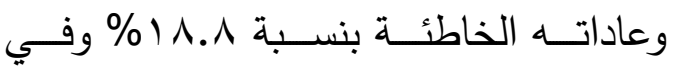
الترتيـب الثالـث الاهتمـام بالناحيـة النفسية للطالب العدواني عن طريق المتابعـة داخل

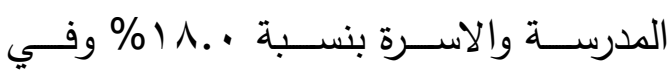
الترتيب الرابع ضرورة تفعيل الارشاد التربوي النفسـي والاجتمــاع فـي المــدارس بنسـبة ع. Y ا \% وفـي الترتيـب الخـامس تطـوير التعليم والمنـاهج والاهتمـام بإعداد المعلمين

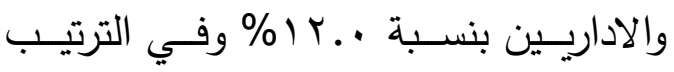
الســادس تحويـلـل الصـف الدراسـي والبيئـة المدرسية الي بيئة مريحة امنة تشجع علي الابــداع بنسـبة .... 1\% وفـي الترتيــب السـابع معرفـة مـا يعـاني منـه الطالب مـن مشكلات ومحاولة حلها بنسبة . . م\%.
الأول إجاد صسوبات كبيره في التكيف ، واقامـة علاقات اجتماعيـة سليمة ومتوافقـة

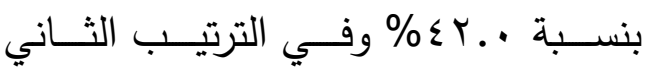

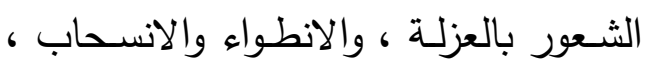
والتي تعد سلوكا انسحابياً بنسبة . .بr\% وفي الترتيب الثالث الثـعور بالخوف والنبذ من قبل المجتمع بنسبة . . r r \%

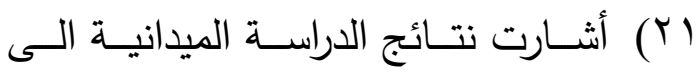
الابعـاد الاقتصـادية للتنمـر المدرسي ففي الترتيب الأول تأخير سـير خطط التنميـة التي تتجـهـ بهـا الدولـة او الحكومـة الـى تطوير المجتمع ومرافقه التي يستفيد منها الفرد بالدرجة الاولى بنسبة ... ؛ \% وفي الترتيـب الثـاني هـدر المـال العـام بنسـبة

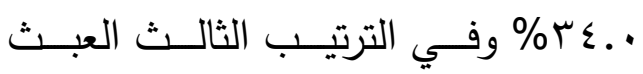
بـالمرافق والامــاكن العامــة مدــا يعرقـلـ تطويرها بنسبة . .7r\%.

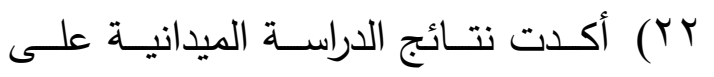

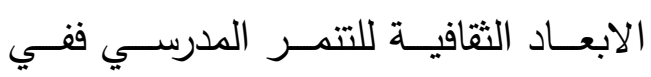
الترتيب الأول النظرة السلبية تجاه ممارس هذا السلوك من ابناء المجتمع ومن الزوار

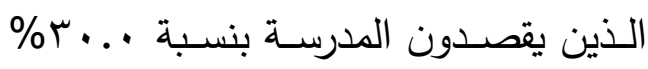
وفي الترتيب الثاني تدني مستوي المكانـة الاجتماعيـة للأسـرة بنسـبة ، ـ ـr\% وفي الترتيـب الثالـث تـدني المسـتوي الثقــافي والفكري للأبناء البلد الذي تكثر فيـه هذه الممارسـات العدوانية خاصسة على الأمـاكن

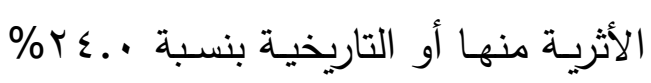
وفي الترتيب الرابع ممارسـة العدوانية تجاه 
r. أبـو غزالـه، معاويـة محمـود 9 ـ . ب التتمـر

وعلاقته بالشعوب بالوحدة والدعم الاجتماعي

، المجلة الاردنية في العلوم التربوية، مجلد

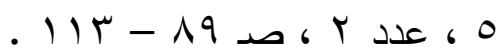

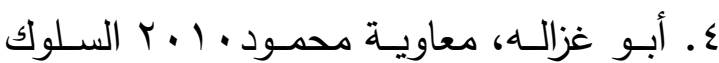

التتمـري مـن وجهـة نظـر الطلبـة المتنمـرين والضــايا، مجلــة جامعــة الثــارقة للعلـوم

الانسانية الاجتماعية ، مجلد V ، عدد Y ،

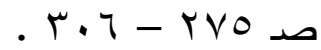

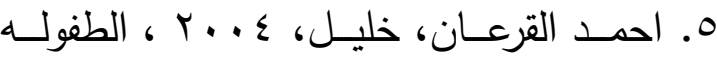

المبكرة ن خصائصـها ، مشكلاتها ، حلولها

، عمان دار الاصراف للنشر والتوزيع.

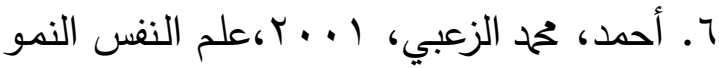

الطفولــــه والمراهقــــهـ ، الاســـس النظريــــة ومشـكلات ، سـبل معالجتهــا، الأردن، دار

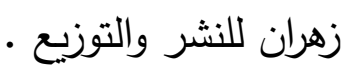

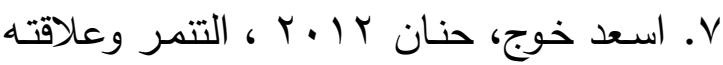

بالمهارات الاجتماعيـة لدي تلاميذ المرحلـة

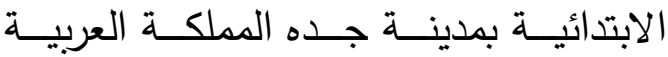

السعودية ـ مجلة العلوم التربوية والنفسية .

$$
\text { مجلد با عدد ع . }
$$

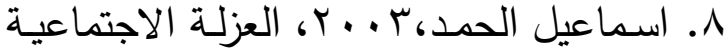

، طـا، دار الثرق للنشر والتوزيع ، عمان ،

$$
\text { الاردن ص عـ . }
$$

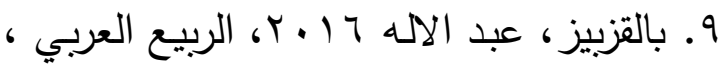

جـاردة حسـاب أوليـة ، مقالـة منشـورة في لـي

مجال المستقبل العربي ، مكتبة الإسكندرية ،

$$
\text { العدد }
$$

\section{حادي عشر: التوصيات والمقترحات:}

•العمل على تطوير التعليم والمناهج والاهتمام

بإعداد المعلمين والادارين.

• تحويل الصف الدراسي والبيئة المدرسية الي

بيئة مريحة امنة تشجع علي الابداع.

• الاهتمـام بالناحيـة النفسية للطالب العدواني

عن طريق المتابعة داخل المدرسة والاسرة.

• معرفة مـا يعاني منـه الطالب من مشكلات

ومحاولة حلها.

• مسـاعدة الطالب علـي التخلص مـن أزماتـه

وتصحيح مفاهيمه وعاداته الخاطئة.

• زيــادة التواصـل بــين المدرســة والمجتمـعح

المحلي من خلال مجالس اولياء الامور .

• ضــرورة تفعيـل الارشــاد التربــوي النفسـي

$$
\text { والاجتماعي في المدارس. }
$$

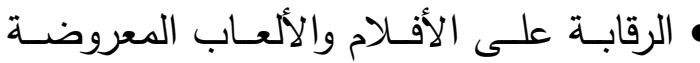

على شاشات التلفاز والإنترنت.

• تقليل عدد الساعات التي يقضيها الفرد أمام

الإنترنت.

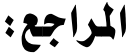

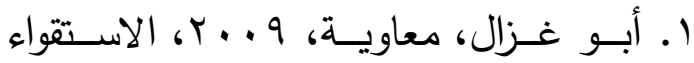

وعلاقتــــه بالثـــعور بالوحــــدة والــــدعم

الاجتمــاعي، "المجلـة الأردنيـة في العلـوم

$$
\text { التربوية" ه (r) ( الته }
$$

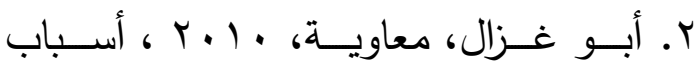

السلوك الاستوائي من وجهة نظر الطلبة

المستقوين الضحايا، "مجلة جامعة الشـارقة

للعلـوم الانسـانية والاجتماعيـة"، مجلـد V 


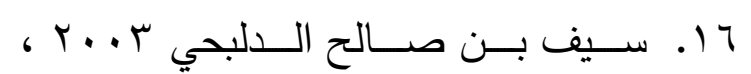

المشــكلات المدرسـية لطــلاب المرحلـــة

$$
\text { الابتدائية ن الرياض. }
$$

IV الأثار النفسية لأحداث العنف لدي طلاب الجامعة ، مجلة العلوم النفسية جامعة بغداد

$$
\text { 6 العدد ع أ. }
$$

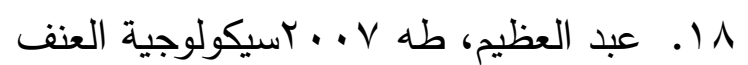
العائلي والمدرسي. الاسكندرية، دار الجامعة

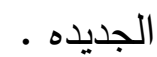

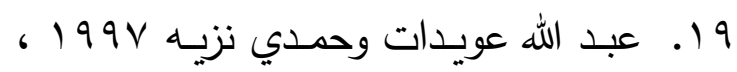

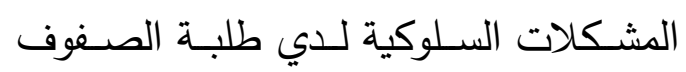
الثامن والتاسـع والعاشـر الذكور في الاردن والعوامـلـ المرتبطـهـه بـهـه ، دراسـات العلـوم

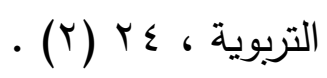

• . . . عبدالله شوقي محم 1999 ، ظاهرة الشغب في مـدارس التعلـيم العـام دراسـة تحليليـة

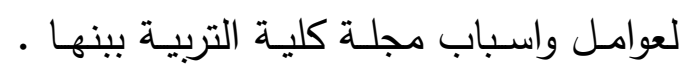

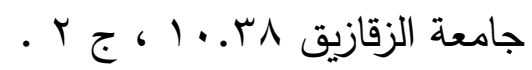

ا r. على الشهري، عبد الرحمن r ب. . العنف فـي المــدارس الثانويسـة مـن وجهــة نظــر المعلمـين رسـالة ماجسـتير غيـر منشـوره جامعـة نـايف العربيـة ن المملكــة العربيـة

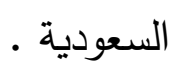

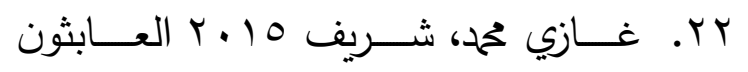
بالممتلكـات العامـة الاحســاس بالمسـؤولية غائب ، صـيفة الريـاض ، على الانترنت العدد | إ I ا في تاريخ 7 اديسمبر •
• . . حجازي فتيانى ابو المكارم . . . ب مدي . فاعليـة برنـامج ارشـادي في تخفيـف حدة السـلوك العـدواني لـدي تلاميـذ المرحلــة

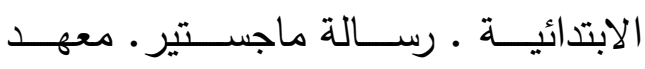
الدراسات العليا للطفولة ، القاهرة .

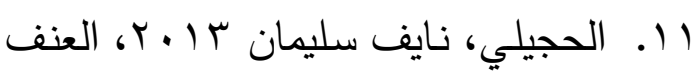
الطلابـي فـي المـدراس مـن وجهـة نظـر

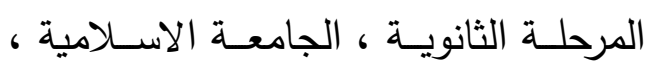
كليــة الــدعوة وأصـــول الـدين ، المملكـة العربية السعودية ، على الانترنت . ז ا . حسين طـه عبد العظيم وحسين سـلامه عبد العظيم • 1 • r ، اسـتراتيجيات وبرامج مواجهــة العنـف والمشــاغبه فـي التعلـيم الإسكندرية ، دارالوفاء . ماركاء

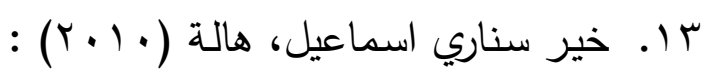
بعـض المتغيـرات النفسـية لـدي ضــايا التمـر المدرسـي في المرحلـة الابتدائيـة ، مجلة الدراسـات التربوية واجتماعية ، كلية التربية ، جامعة حلوان ، ال

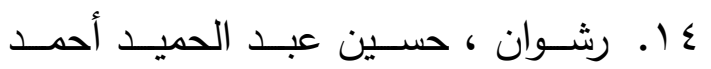
ـ ا ـ ب، ثــورات الربيــع العربــي مقارنــة بثورات العالمية ، مؤسسة شباب الجامعة ،

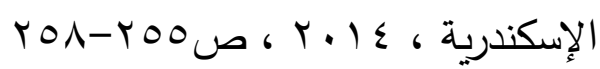
1 . الرشــيدي، الصــالح ه . . ب اتجاهــات المعلمــين نحــو المنــاخ المدرســي فـي المــدارس الثانويــة ذات الفصــلين بدولـــة الكويت ، مجلة تربوية ـ جامعة الكويت .

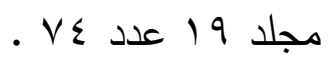




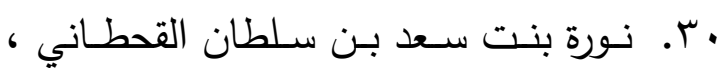

التتمـر بــين طــلاب وطالبــات المرحلــة

المتوسطة في مدينة الريـاض دراسـة مسـية

، دراسـة واقتراح برامج التدخل المضـادة بمـا

يتناسـب مـع البيئة المدرسـية رسـالة دكتوراه

غير منشورة ، كلية التربية ، جامعـة الملك

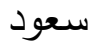

اس ا. نــورة بنــت سـعد بـن سـلطان القحطـاني

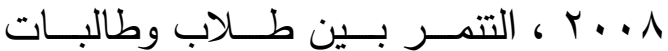

المرحلة المتوسطة في مدينة الريـاض دراسـة

مسـحية ، اطروحـة دكتوراه غيـر منشـورة ،

كلية التربية ، جامعة الملك سعود ، الرياض

$$
\text { ، المملكة العربية السعودية. }
$$

32. Alkison \& Hornby (2002) Mental Health handbook for schools London Routledge Falmer .

33. Bulach , t; Osborn, R\& Samara , M,2012 Bullying in Secondary Schools :What it looks Like aittl How to manage it ? New York : Sage Publishing.

34. Crabarion,S.2003"Personalityand Family Relation of children who bully " Personality \& Individual Difference . 35 - 3 559/567

35. Dickerson. ( 2005 ) Cyber bullies on camp.Retrieved Octobre 52006.Fromthe http://www.unicef.org.violence.

36. Hillsberg \& Spak , 2006 Bullying and psychiatric symptoms among school-age children " Child and Neglect 22 (4), 707/717.

37. Horwood . Waylen .Williams \& Wolke . ( 2005 ) Common visual defects and peer victimization in rr. فرنافـا، جـورج ؟ ... ، طيـف يمكـن

القضـاء على ظـاهره العنف في المـدراس

( خالد العمري- مترجم ) ، القـاهرة ، دار الفاروق للنشر والتوزيح.

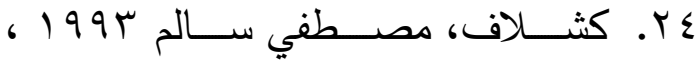

الجـرائم الاقتصـادية في ليبيـا دار الكتب

الوطنيـة ، بنى غـازي ، طرابلس ، ليبيا ،

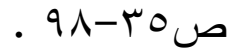

هץ. حمد عادل، عبد الله . . . ب، دراسات في الصـــحة النفسـية - الهويــة والاغتــراب

والاضطرابات النفسية ، ط ا، دار العربية للطابعة والنشر ، القاهرة ص 191 ـ ـ

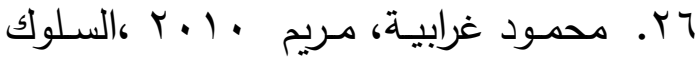
الاستوائي واثر برنـامج تدريبي قائم على دعم الاقران في مواجهتي وتحسين تقدير

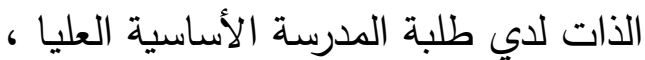
رســالة دكتـوراه غيـر منشـوره ـ جامعــة اليرموك - الئ

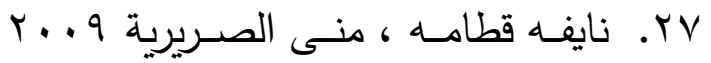
الطفل المتنمر ، دار المسيرة للنشر والتوزيع والطباعة ، عمان.

^r. ن نايفه قطامه ، يوسف قطامه 997 أثر الـذكاء والدافعيـة للإنجــاز علـى اسـلوب تفكير حل المشكلات لدي الطلبة المتفوقين في سـن المراهقة ، مجلـة دراسـات تربويـة، عدد rr ، صد -

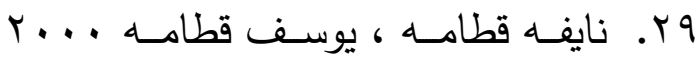
سـيكولوجية الـتعلم الصــفي ، دارالشـروق ل ل لنشر والتوزيع ، عمان 
Eribaum : National School Safety Center, $\mathrm{N} \mathrm{J}$.

43. Olweus, 2005 A Useful Evaluation Design, and Effects of the Olweus Bullying prevention Program, Crime and Law , 11 (4) 389 - 402 Retrieved November , 12, 2006.

44. Olweus, D 1993 . Bullying at School : what we Know and What We can do ? Black Well Publishers .

45. Olweus, D 1993 . Bullying at School : what we Know and What We can do ? Oxford Blackwell.

46. Rigby.K.(2002).New prespectives on Bullying. ( London )Jessica . Kingsley publishers .

47. Rigby . K . Bagshaw , d . ( 2003 ) Addressing Bullying in schools .

48. Smith, et al (2003) interventions to Reduce School Bullying Canadian Journal of Psychiatry 48(9) Prosocially.

49. Storey , K \& slaby , R ( 2008 ) Eyes on bullying what can you do ? Newton : education Development Center . children.investigative

ophthalmology and visual science 46 (4) .

38. John, C.2006 Systemic Patterns in Bullying and Victimization ( Eric Document Reproduction Service No) EJ 738912 .

39. Jordan \& Austin . ( 2012 ) A Review of the literature on bullying in U.S. Schools and how a parent-educator partnership can be an effective way to handlebullying.JournalofAggres sion.

21(4).440.Doi10,1080/1092677 12012.675420 .

40. Kilpatrick , M \& Kerres, M .2003 . Perception of the Frequency and Important of Social Support by Student Classified as A Victims, Bullies Bully / Victim in an Urban Middle School . School Psycology $32.472 / 489$.

41. Larke\&beran.2006.the relationship between bullying and social skills in primary school student . Educational research .

42. Lipson ,2001, 62 Bullying in schools fighting the bully Battle 